Portland State University

PDXScholar

$1-1-1986$

\title{
Values of Oregon Community College Faculty in Selected Instructional Areas
}

John Francis Bohan

Portland State University

Follow this and additional works at: https://pdxscholar.library.pdx.edu/open_access_etds Let us know how access to this document benefits you.

\section{Recommended Citation}

Bohan, John Francis, "Values of Oregon Community College Faculty in Selected Instructional Areas" (1986). Dissertations and Theses. Paper 489.

https://doi.org/10.15760/etd.489

This Dissertation is brought to you for free and open access. It has been accepted for inclusion in Dissertations and Theses by an authorized administrator of PDXScholar. Please contact us if we can make this document more accessible: pdxscholar@pdx.edu. 


\title{
YALUIES OF OREGON COMMUNITY COLLEGE FACULTY
}

IN SELECTED INSTRUCTIONAL AREAS

by

JOHN FRANCIS BOHAN

A dissertation submitted in partial fulfillment of the requirements for the degree of

\author{
DOCTOR OF EDUCATION \\ in \\ COMMUNITY COLLEGE EDUCATION
}

Portland State University

University of Oregon

Oregon State University

1986

(C) 1986 John Francis Bohan 
TO THE OFFICE OF GRADUATE STUDIES AND RESEARCH

The members of the Committee approve the dissertation of John Francis Bohan presented June 27, 1986.

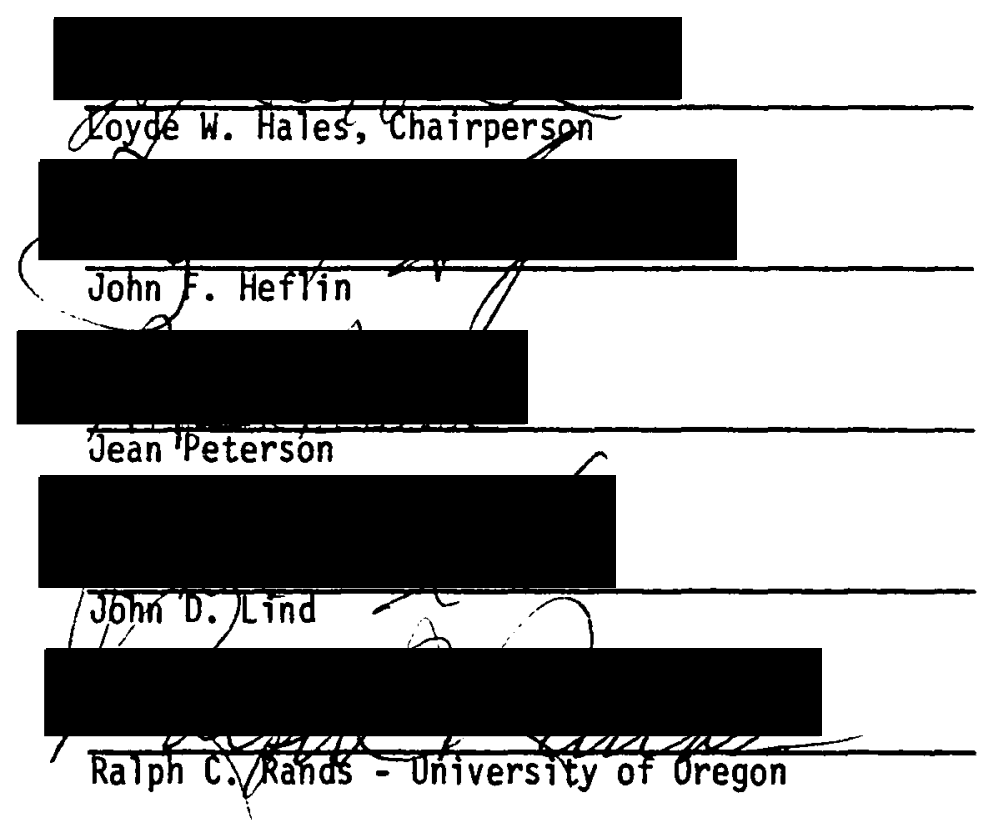

APPRQVED:

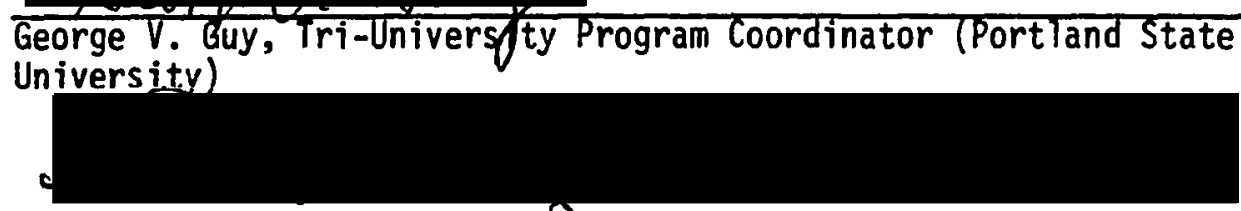

Richard A. Schmuck, Tri-Univenity Program Coordinator (University of Oregon)

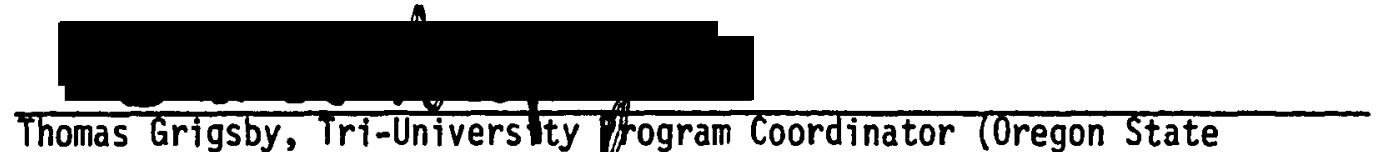
Thomas Grigsby, Tri-Univers ty frogram Coordinator loregon State
Univers ity

Robert Everhart, Dean of the School of Education (Portland State University) 1

Bernard Ross, Dean of Graduate Studies and Research (Portland State University) 
AN ABSTRACT OF THE DISSERTATION OF John Francis Bohan for the Doctor of Education in Community College Education presented June 27, 1986.

Title: Values of Oregon Community College Faculty in Selected Instructional Areas.

APPROVED BY MEMBERS OF THE DISSERTATION COMMITTEE:

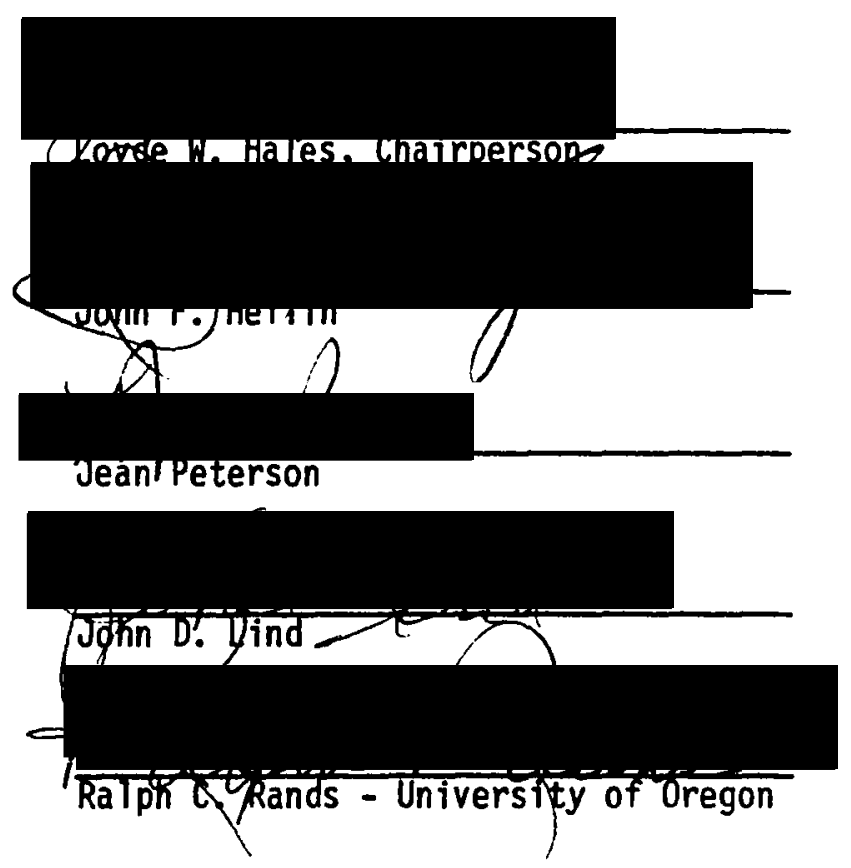

The following question was investigated for each of several biographical variables: Are there significant differences in the work values, as measured by the Ohio Work Values Inventory (OWVI), and personal values (terminal and instrumental), as measured by the Rokeach Value Survey (RVS), of instructors in Oregon community colleges? Comparisons were made by job status (part-time/full-time), teaching assignment, sex, number of years teaching, age, degree held, other employment of instructor, geographic location of college, and vocational 
certificate held. On each of these variables, a multivariate ANOVA (followed by univariate ANOVAs and Modified HSDS as needed) was performed separately on the OWVI scales, the RVS Terminal Values, and the RVS Instrumental Values. The initial sample included 984 Oregon community college instructors, partitioned by teaching status, teaching assignment, and geographic location. The responding sample included 212 full-time and 288 part-time faculty.

The rank order of the OWVI means for instructors was: Task Satisfaction; Self Realization; Ideas/Data; Altruism; Independence; Security; Money; Control; Object Orientation; Prestige and Solitude. Ranking by part-time instructors was in the same order as full-time instructors with the exceptions of Independence being placed ahead of Altruism and Prestige being ahead of Object Orientation.

The rank order for RVS Terminal Values for instructors was: Health; Self Respect; Family Security; Freedom; Inner Harmony; A Sense of Accomplishment; Wisdom; Mature Love; True Friendship; A World at Peace; An Exciting Life; Equality; A World of Beauty; A Comfortable Life; Salvation; Pleasure; National Security and Social Recognition. Ranking by part-time instructors followed generally the same pattern with very few exceptions. The order was: Self Respect; Health; Family Security; Freedom; Wisdom; Inner Harmony; A Sense of Accomplishment; Mature Love; True Friendship; A World at Peace; An Exciting Life; Equality; A World of Beauty; A Comfortable Life; Salvation; Pleasure; Social Recognition and National Security. In comparing the rankings of full-time and part-time instructors seven of the 18 values were in the 
same rank order, and all of the remaining values were within one or two positions of each other.

The rank order for RVS Instrumental Values for instructors was: Honest; Responsible; Loving; Capable; Independent; Intellectual; Helpful; Broadminded; Courageous; Forgiving; Loyal (tied with Forgiving); Logical; Ambitious; Self Controlled; Polite; Clean and Obedient. In comparing the rankings of full-time and part-time instructors, ten of 18 values in this grouping were ranked equally, one was three places different and the remainder were either one or two places different.

Part-time faculty placed greater value than did full-time faculty on Aitruism, Self Realization, Independence, Task Satisfartion, Ideas/Data, Self Respect, Wisdom, Helpful, Honest and Responsible. They placed less value on Object Orientation, A World of Beauty, National Security, Pleasure, Clean, Obedient and Polite.

When analyzed by area of teaching assignment, differences were found on the following yariables: Altruism, Object Orientation, Control, Self Realization, Money, Solitude, Ideas/Data, Prestige, A Comfortable Life, An Exciting Life, A World of Beauty, Family Security, Equality, Freedom, Health, National Security, Salvation, Self Respect, Ambitious, Broadminded, Clean, Courageous, Honest, Imaginative, Independent, Intellectual, Loving, Loyal, Obedient and Responsible. When sex, teaching experience, age, highest degree held, other employment/no other employment and college location were used as independent variables, statistically significant differences were found in each set of dependent variables with the exception of instrumental 
values for teaching experience and college location and terminal values for college location.

of the 396 correlations between the OWVI scales and the RVS values, 162 were significant at the .05 level (41\%). The signs of the correlations indicated a logical relation between the two instruments. 
Dedicated to

MARILYN JACOBS BOHAN

Without whose love and understanding I would not have succeeded in many aspects of $1 \mathrm{ife}$. 


\section{ACKNOWLEDGEMENTS}

A special note of thanks and my appreciation to the memoers of my Dissertation Committee, particularly Dr. Loyde Hales, Chair; Dr. Jean Peterson, Dr. John Hefl in and Dr. Jack Lind from Portland State University, and Dr. Ralph Rands from the University of Oregon. Dr. David Smeltzer, the representative of the Graduate School at Portland State University was also helpful in fulfilling all requirements. These individuals provided me the needed support to finish this dissertation.

A thank you goes to my friend and teaching colleague at Clackamas Community College, Harriet Hinton, for her valued contribution of offering and arranging help in word processing. Thanks also to Mary Scheufeli and students for their expertise on the word processors. Without their offers of help, this dissertation would have been much harder to complete.

Appreciation is extended to the Oregon Community College Association, Oregon community college presidents, and to Roger Bassett, Executive Director of OCCA, for their willingness to endorse the study. It is my hope that it will be of help and interest to all Oregon community colleges.

My thanks also is given to colleagues, friends and relatives who gave me needed encouragement. 
TABLE OF CONTENTS

PAGE

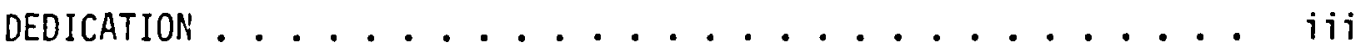

ACKNOWLEDGEMENTS ............................... iv

LIST OF TABLES .................... . . ix

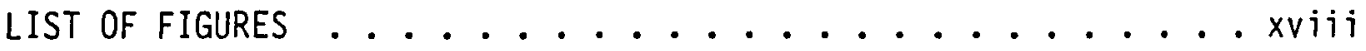

CHAPTER

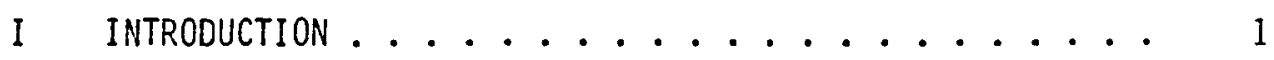

Statement of the Problem ......... 2

Delimitations of the Study.......... 4

Impetus for the Study ........... . 4

Theoretical Foundations and Assumptions ..... 5

Measuring Values............. 7

Life Values .............. . . 7

Work Values ............... 10

Importance of Values to Teaching . . . . . . 12

Summary ................ 15

II REVIEW OF RELATED LITERATURE . . . . . . . . . 16

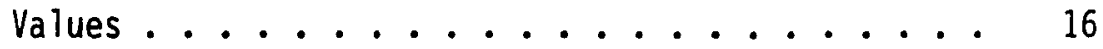

Work Values .............. 20

Measurement of Work Values .......... 24

Personal Values ................ 27

Value-Types of Individuals ......... 31

Values and Teaching .......... 32

Summary .............. 33 
III GENERAL METHODOLOGICAL DESIGN ............ 34

Design of the Investigation ........ 34

Sampling .................... 35

Instrumentation ............... 37

Data Gathering Procedures ......... 43

Statistical Design ........... . . 45

Summary .................. 46

IV PRESENTATION OF THE FINDINGS ........... 48

Sample..................... 48 48

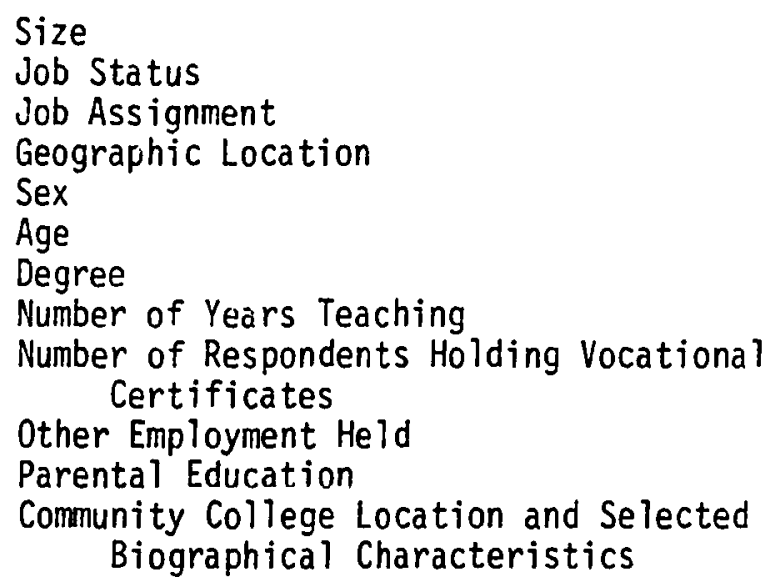

Scoring the OWVI

Summary of the Scores

Altruism

Object Orientation

Security

Control

Self Realization

Independence

Money 
Task Satisfaction

Sol itude

Ideas/Data Orientation

Prestige

Measurement Characteristics of the Instrument

Descriptive Statistics for the Value Survey . . . 73

Scoring of the Rokeach Value Survey

Rankings of the Rokeach Terminal Values

Summary of the Rokeach Terminal Values

Rankings of the Rokeach Instrumental Values

Summary of the Rokeach Instrumental Values

Values by Faculty Status . . . . . . . . . 85

Work Values

Rokeach Terminal Values

Rokeach Instrumental Values

Values by Job Assignment . . . . . . . . . 95

Work Values

Rokeach Terminal Values

Rokeach Instrumental Values

Values by Sex of Instructor . . . . . . . . . 114

Work Values

Rokeach Terminal Values

Rokeach Instrumental Values

Values by Number of Years Teaching . . . . . . . . 123

Work Values

Rokeach Terminal Values

Rokeach Instrumental Values

Values by Age of Instructor . . . . . . . 136

Work Values

Rokeach Terminal Values

Rokeach Instrumental Values

Values by Degree Held . . . . . . . . . . 150

Work Values

Rokeach Terminal Values

Rokeach Instrumental Values 
Values by 0ther Employment.......... 165 Work Values Rokeach Terminal Values Rokeach Instrumental Values

Values by Location of College .......... Work Values Rokeach Terminal Values Rokeach Instrumental Values

Relationships Between OWVI and RVS Values .... 182 $\checkmark$ SUMMARY, CONCLUSIONS, IMPLICATIONS AND RECOMMENDATIONS

Summary ..................

Combined Sample Analysis

Faculty

Job Ass ignment

Years Employed

Age

Highest Degree Held

Other Job/No Other Job Community College Location

Relationships Between OWVI and RVS Values

Conclusions . . . . . . . . . . 206

Part-time, Full-time Values

Teaching Field Values

Sex of Instructor

Number of Years Teaching

Age of Instructor

Degree Held by Instructor

Values Held by Other Employment

Location of College

Correlations of OWVI and the Rokeach Value Survey

Implications for Community Colleges ....... 214

Recommendations for Further Research . . . . . 216

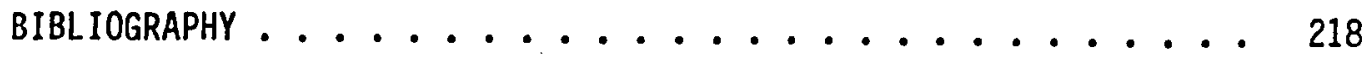

APPENDIX A . . . . . . . . . . . . . . 227

APPENDIX B . . . . . . . . . . . . . . . . 242

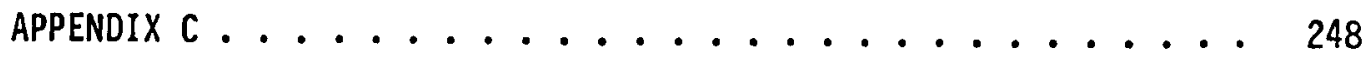


LIST OF TABLES

TABLE

PAGE

I Coefficient Alpha for each OWVI Scale...... 39

II OWVI Scale Correlations ........... 40

III Test-Retest Reliabilities of 18 Terminal and 18 Instrumental Values ............ 44

IV Return Rate of Questionnaires .......... 49

V Job Status of Sample ............ 49

VI Current Job Assignment ........... 50

VII Geographic Distribution of Sample . . . . . . 52

VIII Sex of Sample.............. 52

IX Age of Sample.............. 53

X Highest Degree Held ............. 54

XI Years of Teaching Experience ......... 55

XII Number and Percentages of Respondents with Vocational Certificates........... 55

XIII Other Employment and Type of Position Held .... 56

XIV Parental Education in Years ........... 57

XV Years Teaching by Geographic Location of Community

College Employment .......... 58

XVI Highest Degree Held by Geographic Location of Community College Employment........... 60

XVII Vocational Certificate Held by Geographic Location of Community College Employment ........ 61

XVIII Job Title of Other Employment Held by Geographic Location................... 62 
XIX Assignment of OWVI Items to Scales ....... 63

XX Means and Standard Deviations for OWVI

Scales.................... 65

XXI Coefficient Alpha for Each Scale of the OWVI . . . 70

XXII Scale Intercorrelations of the OWVI ....... 71

XXIII Means and Standard Deviations for RVS Terminal Values 75

XXIV Means and Standard Deviations for RVS Instrumental

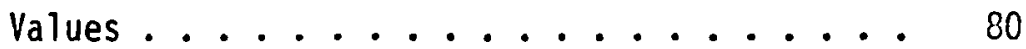

XXV Means and Standard Deviations for the Scales of the

OWVI for Part-time and Full-time Faculty . . . 86

XXVI Rank Order of Work Values for Full-time and Part-time Faculty .................. 87

XXVII Analysis of Variance for Job Status using Work Values as Dependent Variables ........ 88

XXVIII Means and Standard Deviations for the Terminal Values of the RVS for Full-time and Part-time Faculty 89

XXIX Rank Order of the Rokeach Terminal Values for

Full-time and Part-time Faculty. . . . . . 90

XXX Analysis of Variance Table for Job Status, using Rokeach

Terminal Values as Dependent Variables .... 92

XXXI Means and Standard Deviations for the Instrumental Values of the RVS for Full-time and Part-time Faculty 93

XXXII Rank Order of the Rokeach Instrumental Values for

Full-time and Part-time Faculty. ....... 94

XXXIII Analysis of Variance Table for Job Status, using Rokeach

Instrumental Values as Dependent Variables . . . 96 
TABLE

PAGE

XXXIV Scale Means on the Ohio Work Values Inventory for the Levels of Job Assignment . . . . . . . 97

XXXV Scale Standard Deviations on the Ohio Work Values

Inventory for the Levels of Job Assignment . . . 98

XXXVI Analysis of Variance Table for Job Assignment Variable using Work Values as Dependent Variables . . . 100

XXXVII Significant Pair-wise Mean Comparisons between Levels of Job Assignment on the Ohio Work Values Inventory

XXXVIII Rank Order of Work Values for Instructors classified by Job Assignment ........... 102

XXXIX Scale Means on the Rokeach Terminal Values Survey for Levels of Job Assignment . . . . . . . 105

XL Scale Standard Deviations on the Rokeach Terminal

Value Survey for the Levels of Job Assignment

XLI Analysis of Variance Table for the Job Assignment

Variable using Terminal Values as Dependent

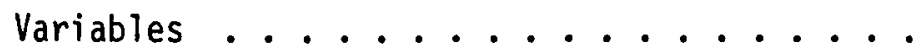

XLII Significant Pair-wise Mean Comparisons between Levels of Job Assignment on the Rokeach Terminal Values 108

XLIII Scale Means on the Rokeach Instrumental Value Survey for Levels of Job Assignment . . . . . . 110

XLIV Scale Standard Deviations on the Rokeach Instrumental Value Survey for Levels of Job Assignment . . . 111

XLV Analysis of Variance Table for the Job Assignment Variable using Instrumental Values as Dependent Variables ............ 112 
XLVI Significant Pair-wise Mean Comparisons between Levels of Job Assignment on the Rokeach Instrumental

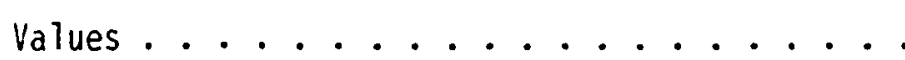

XLVII Means and Standard Deviations for the Scales of the OWVI for Male and Female Instructors . . . . 115

XLVIII Analysis of Variance Table for Sex using k'ork Values as Dependent Variables. .......... 116

IL Means and Standard Deviations for the Terminal Values of the RVS for Male and Female Faculty ..... 117

$L \quad$ Analysis of Variance Table for Sex using RVS Terminal Values as Dependent Variables ........ 119

LI Means and Standard Deviations for the Instrumental Values of the RVS for Male and Female Faculty

LII Analysis of Variance Tabie for Male and Female Instructors using Instrumental Values as Dependent Variables .............. 122

LIII Scale Means on the Ohio Work Values Inventory for Levels of Teaching Experience ........... 124

LIV Scale Standard Deviations on the Ohio Work Values Inventory for the Levels of Teaching . . . . 125

LV Analysis of Variance Table for the Levels of Teaching Experience using Work Values as Dependent Variables ...............

LVI Significant Pair-wise Mean Comparisons between Levels of Teaching Experience on the Ohio Wiork Values Inventory . . . . . . . . . . 128 
LVII Scale Means on the Rokeach Terminal Values Survey for the Levels of Teaching Experience . . . . . 129

LVIII Scale Standard Deviations on the Rokeach Terminal Values for the Levels of Teaching Experience . . . . 130

LIX Analysis of Variance Table for the Number of Years Teaching Variable using Terminal Values as Dependent Variables . . . . . . . . 132

LX Significant Pair-wise Mean Comparisons between Levels of Teaching Experience on the Rokeach Terminal

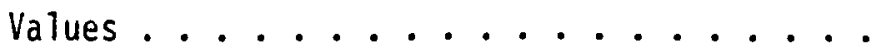

LXI Scale Means on the Rokeach Instrumental Values Survey for the Levels of Teaching Experience. . . . . 134

LXII Scale Standard Deviations on the Rokeach Instrumenta] Values Survey for the Levels of Teaching Experience ................ 135

LXIII Scale Means on the Ohio Work Values Inventory for the Levels of Age. . . . . . . . . . 137

LXIV Scale Standard Deviations on the Ohio Work Values Inventory for the Levels of Age. . . . . 138

LXV Analysis of Variance Table for Age using Work Values as Dependent Variables...........

LXVI Significant Pair-wise Mean Comparisons between Levels of Age on the Ohio Work Values Inventory.... 140

LXVII Scale Means on the Rokeach Terminal Values Survey for the Levels of Age ........... 
LXVIII Scale Standard Deviations on the Rokeach Terminal Values Survey for the Levels of Age . . . . 142

LXIX Analysis of Variance Table for Age using Terminal Values as Dependent Variables ....... 144

LXX Significant Pair-wise Mean Comparisons for the Levels of Age on the Rokeach Terminal Values . . . . 145

LXXI Scale Means on the Rokeach Instrumental Values Survey for the Levels of Age . . . . . . . 146

LXXII Scale Standard Deviations on the Rokeach Instrumental Values Survey for the Levels of Age . . . . . 147

LXXIII Analysis of Variance Table for Age using Instrumental Values as Dependent Variables. ....... 149

LXXIV Significant Pair-wise Mean Comparisons between Levels of Age on the Rokeach Instrumental Values . . 150

LXXV Scale Means on the Ohio Work Values Inventory for Levels of Highest Degree Held . . . . . . 151

LXXVI Scale Standard Deviations on the Ohio Work Values Inventory for Levels of Highest Degree Held . . 152

LXXVII Analysis of Variance Table for Highest Degree Held using Work Values as Dependent Variables .... 154

LXXVIII Significant Pair-wise Mean Comparisons between Levels Of Highest Degree Held on the Ohio Work Values Inventory ............... 155

LXXIX Scale Means on the Rokeach Terminal Values Survey for the Levels of Highest Degree Held . . . . 156 
LXXX Scale Standard Deviations on the Rokeach Terminal

Values Survey for the Levels of Highest Degree Held ............... 157

LXXXI Analysis of Variance Table for Highest Degree Held using Terminal Values as Dependent Variables . .

LXXXII Significant Pair-wise Mean Comparisons between Levels of Highest Degree Held on the Rokeach Terminal

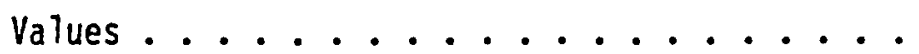

LXXXIII Scale Means on the Rokeach Instrumental Values

Survey for the Levels of Highest Degree Held . . 161

LXXXIV Scale Standard Deviations on the Rokeach Instrumental

Values Survey for the Levels of Highest Degree

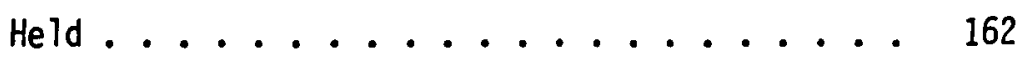

LXXXV Analysis of Variance Table for Highest Degree Category using Instrumental Values as Dependent Variables 164

LXXXVI Significant Pair-wise Mean Comparisons between Levels of Highest Degree Held on the Rokeach Instrumental Values ........... 165

LXXXVII Scale Means and Standard Deviations on the Ohio Work Values Inventory for the Other Job/No Other Job Variable............. 166

LXXXVIII Analysis of Variance Table for Other Job/No Other Job using Work Values as Dependent Variables . . . 167

LXXXIX Scale Means and Standard Deviations for Rokeach Terminal Values Survey for the Other Job/No Other Job Variable ............. 169 
XC Analysis of Variance Table for Other Job/No Other Job using Rokeach Terminal Values as Dependent Variables ...............

XCI Scale Means and Standard Deviations on the Rokeach Instrumental Values Survey for the Other Job/No Other Job Variable ...........

XCII Analysis of Variance Table for Other Job/No Other Job using Rokeach Instrumental Values as Dependent Variables. . . . . . . . . . .

XCIII Scale Means and Standard Deviations on the Ohio Work Values Inventory for Levels of College Location

XCIV Analysis of Variance Table for College Location using Work Values as Dependent Variables . . . . . 177

$\mathrm{XCV} \quad$ Significant Pair-wise Mean Comparisons between Levels of Teaching Location on the Ohio Work Values Inventory. . . . . . . . . . 178

XCVI Scale Means and Standard Deviations on the Rokeach

Terminal Value Survey for Levels of College Teaching Location .......... 179

XCVII Scale Means and Standard Deviations on the Rokeach

Instrumental Value Survey for the Levels of College Teaching Location ........ 181

XCVIII Correlations between OWVI and RVS Terminal Values . . 183

IC Probabilities Associated with the Statistically Significance Correlations between the OWVI Scales and the RVS Terminal Scales ...... 185 
xvi

C Correlation between OWVI and RVS Instrumental Values 187

CI Probabilities Associated with the Statistically

Significance Correlations between the OWVI

Scales and the RVS Instrumental Scales.... 188 
xviii

LIST OF FIGURES

$\begin{array}{ll}\text { FIGURE PAGE } & \end{array}$

1. Determinants of a Value .......... 30 


\section{CHAPTER I}

\section{INTRODUCTION}

\section{Values and Value Systems}

Many authors have written of values and defined them in many ways. Inlow (1972) said, "Values to me, simply stated, are the determiner in man that influences his choices in life and thus decide his behavior" (p. 2). In 1957, Super defined values as the "qualities which people desire and which they seek in the activities in which they engage, in the situation which they live, and in the objects they make or acquire" (p. 4$)$.

Thus value maybe defined as an enduring belief that a specific mode of conduct or end-state of existence is personally or socially preferable to an opposite or converse mode (Rokeach, 1968). Values are ways of striving, believing, and doing whenever purpose and direction are involved, or choice and judgement are exercised (Allport, 1961). Furthermore, Rokeach (1973) wrote:

To say that a person has a value is to say that he has an enduring prescriptive or proscriptive belief that a specific mode of behavior or end-state of existence is preferred to an opposite mode of behavior or end-state. This belief transcends attitudes toward objects and toward situations; it is a standard that guides and determines actions, attitudes toward objects and situations, ideology, presentations of self to others, evaluations, judgements, justifications, comparisons of self with others, and attempts to influence others. Values serve adjustive, ego-defensive, knowledge and self-actualizing functions. (p. 25) 
Rokeach (1973) stated assumptions that would characterize the nature of values:

There are five assumptions about the nature of values: (1) the total number of values that a person possesses is relatively small; (2) all men everywhere possess the same values to different degrees; (3) values are organized into value systems; (4) the antecedents of human values can be traced to culture, society and its institutions, and personality; and (5) the consequences of human values will be manifested in virtually all phenomena that social scientists might consider worth investigating and understanding. ( $p .3)$

Values begin to develop within each individual at an early age, are internalized and integrated into a value orientation or system (Combs and Snygg, 1959; Rokeach, 1973), and are extended to the world of work (work values), beginning in the elementary school years (Hales and Fenner, 1972).

Value systems (Hartman, 1977) of an individual may be divided into sub-systems, one of which is the work values system, an extension of an individual's values to the world of work. Life values are an integral part of personality and the extension of life values to the sub-sets of personal values as envisioned by Rokeach (1973) and work values as stated by Fenner and Hales (1974) contribute to the wholeness of each individual.

\section{Statement of the Problem}

Few studies have been conducted on the instrumental and terminal values of the faculty of community colleges (Brawer, 1971; Blai, 1972; Park, 1971; Pritchett, 1973). None of these studies examined values by part-time/full-time employment or by teaching assignment; Pritchett (1973) also included other professional staff in the sample. No study 
examining the work values of community college faculty was located. Thus, there is a need for information concerning the work and life values of community college faculty.

The primary purpose of this study was to examine the work values and life values of community college faculty in selected teaching assignments, as measured by the Ohio Work Values Inventory (Fenner and Hales, 1974) and the Rokeach Value Survey (Rokeach, 1973). Using teaching status (part-time/full-time) and teaching assignment as independent variables, the following question was investigated: Are there significant differences in the work and life (termina?, instrumental) values of instructors in Oregon community colleges?

A secondary purpose of this study was to explore the values of community college faculty by selected (demographic) variables. Thus, for each of these variables the following question was investigated: Are there significant differences in work and life values of instructors in Oregon community colleges when examined by (1) sex of the instructor, (2) number of years teaching of the instructor, (3) age of the instructor, (4) highest degree held, (5) other employment - yes/no, (6) job location - geographic area of college, (7) vocational certificate of instructor - yes/no, and (8) parental education of instructor.

Although of minor importance to the purpose of this study to describe the values of community college faculty, the relationships between work and life values were briefly examined. The relationships among these values should be useful to researchers in the area of value theory. 
Delimitation of the Study

The unique population sampled, Oregon community college instructors, delimit the study. Also, the sample was stratified by teaching status and teaching assignment, with equal numbers in each cell being randomly selected in so far as available samples permitted. In generalizing this study's results, one should take into account the characteristics of the population sampled. The values definition as described by Rokeach delimited the scope of the study to only those values and limited the generalizations to Rokeach's 36 terminal and instrumental values. Finally, Hales and Fenner's described 11 work values delimited the scope of the study. The work values should not be interpreted or be reflected to other values defined by other authors.

\section{Impetus for the Study}

The researcher has been active in developing in-service programs for instructors at Clackamas Community College. A seminar was developed for part-time instructors to help them develop basic instructional skills. This seminar has been offered to approximately 70 participants at seven different sessions. The seminar was instituted because many part-time instructors in community colleges had been hired for their personal expertise in a given trade, industrial or other field, but with no formal pedagogical training to enable them to communicate this information to students. Under the auspices of the Staff Development Office at Clackamas Community College, a one-weekend, 
inservice program focusing on teaching and student evaluation methods was developed, conducted, and evaluated by the researcher.

The thought then occurred to the researcher that part-time faculty may differ from their full-time counterparts not only in the extent of their on-the-job and formal pedagogical training, but also in their life and work values. If values influence the way an individual responds in various social situations (including the classroom) and to different instructional methods, then a knowledge of the values of part-time faculty should contribute to more effective in-service training programs and this, should, in turn result in better instructional programs for college students. Thus came a recognition of a need for base-line data on the values of community college faculty, and out of this recognition emerged the previously discussed research problem.

\section{Theoretical Foundations and Assumptions}

There is a tendency for people within a culture to be somewhat similar in regards to most values. Primarily, they differ in the values they hold because of background and other deteriminants.

In the area of work values, demographic variables account for some differences. For example, a study of fifth-, eighth-, and eleventh-grade children in three southeastern Ohio public schools found that work values of the two lower grades were different from the upper grade leve? (Hales and Fenner, 1972). Hales and Hartman (1978b) found that sex was a contributing factor in that female and male undergraduate university students differed somewhat as to work values. Hartman (1977) found that two-year vocational technical college students classified by major 
differed somewhat in their work values. A studij of practicing nurses and nurses in training (Hales 19ii) found no significant differences in work values. Fillally, Klampe (1983) in a study of secondary school ceachers, found significant differences among teaching fields in work values. All of these studies were done using the Ohio Work Values Inventory (OWVI).

An instrument which has been used with many groups to measure personal values is the Rokeach Value Survey. For example, Feather (1975) used the RVS, at Flinders University in Adelaide, Australia, to examine whether students would enter a particular school because of the values they hold. As Feather stated:

There was evidence from the comparison of median rankings that the student's own value systems more closely resembled the perceived value systems of the school they entered than the perceived value systems of the schools they rejected, the results being most clean-cut for Humanities students. (p.68)

Rokeach (1973) reported that the RVS has been utilized with subjects in many occupational areas for ranking values. A study of policemen showed that police of varying age, rank and experience on the police force do not differ in value patterns, thus suggesting that socialization after recruitment is not a determinant of police values (p. 152). Values of business executives, scientists, writers and artists in Calcutta, India were studies using the RVS and showed that significant value differences were found for these professional groups (p. 155). Small entrepreneurs (service station dealers) and salesmen for an American oil company, on a national basis, were studied showing that salesmen were more achievement-, status-, and competence-oriented and more concerned with personal values than were dealers, and less 
concerned with conventional moral values such as clean, forgiving, obedient and polite. Teachers and students in all levels of education have been studied using the RVS. The studies overall suggested that "certain values are employed equally often as standards guiding attitude and behavior, that others are mainly employed as standards guiding attitudes and that yet others are mainly employed as standards guiding behavior. There is no reason to think that values must serve equally as standards to guide attitudes and action" (p. 162). These reports indicated that the RVS has widespread useage in many areas of endeavor.

Therefore, it may be said that values do exist, that they form an integral part of personality, that individuals differ in values they hold, and that values may be related to various demographic variabilities.

\section{Measuring Values}

This study is concerned in measuring two types of values: life values and work values.

\section{Life Values}

Life values, as envisioned by Rokeach, are reported on in a number of books, including Feather's (1975) Values in Education and Society. Rokeach's values fall into two categories: one is a list of terminal values, and the other is a list of instrumental values. Each list is ranked by a respondent who is instructed "to arrange them in order of importance to YOU, as guiding principles in YOUR life" (Feather, 1975, p. 27). The ranking method assumes that it is not the absolute presence or absence of a value that is of interest but their relative ordering. 
These lists then become two hierarchies of a value system for each respondent.

The selection of the sets of 18 terminal and 18 instrumental values was made in the following manner, according to Rokeach (1973). The terminal list was distilled from a list of several hundred values obtained from various sources: a review of literature on values in American society and other societies; Rokeach's analys is of his own terminal values; the values reported by a representative sample of about 100 adults in Lansing, Michigan; and the values reported by a group of 30 graduate students in psychology, all of whom had had the notion of terminal values explained to them. After values were excluded that were synonomous or overlapping, too specific, or not really concerned with end-states of existence, it was possible to reduce the number of terminal values to a list of 18 .

The instrumental values were obtained from an analysis of Anderson's (1968) list of 555 personality-trait words (Rokeach, 1973). This list was reduced in several ways, including taking out negative values and retaining those which provided maximal discrimination across social status, sex, age, religion, politics, etc. These two lists seemed to be sufficiently general to make the RVS an appealing instrument for social research.

The Rokeach Value Survey list of values include the following: TERMINAL VALUES (Idealized end-states of existence)

A Comfortable Life (a prosperous life) An Exciting Life (a stimulating, active life) A Sense of Accomplishment (lasting contribution) A World at Peace (free of war and conflict) A World of Beauty (beauty of nature and the arts) Equality (brotherhood, equal opportunity for all) 
Family Security (taking care of loved ones)

Freedom (independence, free choice)

Health (a sense of mental and physical well-being)

Inner Harmony (freedom from inner conflict)

Mature Love (sexual and spiritual intimacy)

National Security (protection from attack)

Pleasure (an enjoyable, leisurely life)

Salvation (saved, eternal life)

Self Respect (self-esteem)

Social Recognition (respect, admiration)

True Friendship (close companionship)

Wisdom (a mature understanding of life)

INSTRUMENTAL VALUES (Idealized modes of behavior)

Ambitious (hard-working, aspiring)

Broadminded (open-minded)

Capable (competent, effective)

Clean (neat, tidy)

Courageous (standing up for your own beliefs)

Forgiving (willing to pardon others)

Helpful (working for the welfare of others)

Honest (sincere, truthful)

Imaginative (daring, creative)

Independent (self-reliant, self-sufficient)

Intellectual (intelligent, reflective)

Logical (consistent, rational)

Loving (affectionate, tender)

Loyal (faithful to one's friends and groups)

Obedient (dutiful, respectful)

Polite (courteous, well-mannered)

Responsible (dependable, reliable)

Self Controlled (restrained, self-disciplined)

(Rokeach, 1973, p.22)

The Rokeach Value Survey has been used in a number of surveys of

community college faculty as well as public education. Cohen and Brawer

(1977) wrote:

Faculty members in three California colleges responded to the scales in 1969 (Brawer, 1971; Park, 1971), and they were used in a study of staff members in Oregon community

colleges in 1973 (Pritchett, 1973). In addition, scales were administered to elementary and secondary teachers in 1972 (Sikula, et al, 1972). The respondents to the Faculty Survey also ranked the Terminal Value Scale (Rokeach, 1968). Thus, there is quite a bit of comparative data. ( $p .22$ ) 
Work Values

Whereas the Rokeach Value Survey is concerned with values which include personal traits, the Ohio Work Values Inventory is primarily concerned with work values that each individual possesses. The two instruments may overlap in certain areas and the analysis of the data should bring these factors out.

The Ohio Work Values Inventory (OWVI) as described in the OWVI Manual states (Fenner and Hales, 1974):

It is not customary for people to give conscious thought to the relative priority of their values, one to another. Yet, at the heart of effective decision-making and of compromise exists a mandate for a clear and ordered set of values. . .

The OWVI is intended for use by a variety of vocational development workers. Vocationalists . . can assist potential workers, from pre-adolescents to adults, to explore their work values and to better integrate these preferences into their consideration of occupational possibilities. (pp. 1-2)

An understanding of work values can help an instructor understand stress factors in the job setting when the job setting does not allow one to achieve those job values. An understanding of work values can aid schools in the development of in-service programs to help instructors deal more effectively with the demands of their job.

According to the authors of the Ohio Work Values Inventory (Hales and Fenner, 1973a), which is the instrument employed in this research to measure the work values of instructors, the theoretical foundations of the OWVI can be traced to the following: the personality theory of Horney (1945); the personality-need theory as postulated by Maslow (1954) and adapted to an occupational choice theory by Roe (1956); 
worker functions, identified by the United States Department of Labor; self-theory as presented by Combs and Snygg (1959); and an analysis of the values used in previous investigations.

The following are the definitions of the constructs of the ohio Work Value Inventory employed in this study (Fenner \& Hales, 1974).

Altruism

Signifies the importance given to the opportunity for involvement with other people in a helping, supportive, or service role. A quality of interpersonal giving by the valuer characterizes the relationships which are developed in the work.

Object Orientation

Expresses the valuation of handling, tending, or manipulating physical objects such as utensils, materials, tools, or apparatus. The value relates to work which involves making, fixing, operating, or changing the appearance of things, the results of which tend to be readily apparent and measurable.

Security

Concerns the desire for work which is steady and dependable. The work may be full-time, part-time or seasonal but it is quite immune to unpredictable layoff or dismissal. Since a guarantee of income is reflected in high valuation of security, the value tends to be related to other rewards-of-work values Money and Prestige.

Control

Indicates the importance of having an opportunity to take a leadership role or responsibility for other workers in the conduct of their work. The job itself gives the person an influencing or decision-making role with regard to the planning, supervision, and evaluation of workers.

Self Realization

Expresses a preference toward work which permits the individual to utilize his skills, abilities, or talents. The work affords opportunities and challenges for continued personal growth and realization of one's full potential.

Independence

Signifies the importance of work which allows the person to determine his own working conditions. A high scorer on this scale prefers to be free from close supervision and to structure his own hours and methods of working. An element of control -. the desire for mastery over the work 
environment -- is expressed in this value. Thus, the scale may be related to the Control scale which reflects a managerial factor regarding people.

Money

Indicates the importance of work which enables the person to have a substantial income -- more than enough to assure basic needs. The value reflects a materialistic outlook -one in which the person's desires for material satisfactions and the psychological gratifications attendant upon wealth can be realized.

Task Satisfaction

Concerns the importance associated with work that generally is interesting and enjoyable. The work tasks are that kind an individual can, for the most part, look forward to doing.

Solitude

Relates to the preference for work situations characterized by the absence of close relationships with other people. The work can be done largely by one person and it usually affords either few or brief structured personal encounters.

Ideas/Data

Indicates the importance of having an opportunity to work with facts and ideas. A high score on this scale signifies a preference for dealing with, making sense out of, creating and communicating ideas.

\section{Prestige}

Concerns the desire for work which will bring a person recognition and acclaim. An aspect of this value is the opportunity to meet or associate with important people. (pp. $9 \& 10)$

\section{Importance of Values to Teaching}

"Values are an intrinsic aspect of human motivation, a fundamental characteristic of healthy, human life", according to Canning (1970, p. 51). Schiebe (1970, p. 53) stated: "Behavior is a function of beliefs and values". When values thus become part of life, we are motivated and led by the values that we have had instilled in us. 
Human values, according to Rokeach, an outstanding scholar in the study of values and how they apply to the area of teaching, would imply for teachers that values are inseparable from the teaching skills of an individual. He stated (1968):

Once a value is internalized, it becomes, consciously or unconsciously, a standard or criterion for guiding action, for developing and maintaining attitudes toward relevant objects and situations, for justifying one's own and others' actions and attitudes, for morally judging self with others, and for comparing self with others. Finally, a value is a standard employed to influence the values, attitudes, and actions of at least some others. (p. 160)

Through the analysis of the RVS in many areas, there is a common thread that shows that values are used by individuals as a necessary component of the teaching process and that our internalized attitudes and values will generally become part of our teaching skills and that those attitudes tend to enhance teaching abilities.

Among studies conducted using the Rokeach scales was a study by Blai (1972) which surveyed faculty at a Pennsylvania junior college, as well as a study by Brawer (1971) of values of junior college faculty and freshmen. These studies found that values do indicate one fruitful way of examining people. It was felt that ways could be found to better understand people who function in the educational system. Brawer (1971) went on to state that values presented an "operationally feasible approach to the comparison of various groups according to basic and what seems to be relatively enduring dimensions of personality" (p. 44). The RVS may be used as a "means of assessing not only the underlying features of the individual personality but for predicting future behavior". (p. 42) 
Teaching practices and attitudes of faculty do vary, according to Wilson and Gaff (1975). Community college faculty stress a studentcentered approach in general and have extrinsic motivation to communicate their own enthusiasm. This type of "teaching and student involvement" then should become a concern for community college faculty members. There is a great diversity of college students in the community college setting and all of their needs should have the attention of educators. Teaching this type of individual should be of great concern for community college educators. According to 0'Banion (1977):

A teacher... is engaged for what she or he knows: the ability to help others to know is assumed and presumed to grow with experience. . . No clear consensus exists on how to assess the teaching skills of a candidate for employment. Many instructors are recruited from business and industry, where their teaching skills and abilities have never been evaluated. (p. 27)

Values form a very large part of teaching abilities and skills. If we measure the values of individuals who teach part-time and find them to be similar to other individuals who teach full-time and whom we consider to be good instructors, then we have a basis of comparison from which to work.

Pritchett (1973) stated:

A number of researchers have concentrated on values and value orientations. Their theory is that people express their values by selecting, prizing, evaluating, and acting. Therefore, it follows that there is a relationship between a person's values, his personal goals and his behavior. (p. 2)

When this relationship is extended to the teaching profession, the concept of values would seem to imply for instructors that values are inseparable from teaching. 


\section{Summary}

With the advent of a greater number of part-time instructors being employed by community colleges throughout the nation and in the state of Oregon, and realizing that there may be need for in-service programs to promote value consciousness, the results of this study of the values of community colleges faculty by job status and selected teaching assignments as well as selected biographical characteristics as measured by the Ohio Work Values Inventory and the Rokeach Value Survey, should help administrators of community college plan in-service programs that will be of benefit to the faculty, the college, and the student body of each school. 
CHAPTER II

\section{REVIEW OF RELATED LITERATURE}

A review of the literature revealed no systematic study of the life and work values of Oregon community college instructors. Although Pritchett (1973) did conduct a study of the values of community college staff, her study focused on life values of full-time instructors, as well as other selected professional staff. No study of the work values in general, the relationship among work and life values, and the value difference between full-time and part-time faculty by teaching assignment and other biographical characteristics has been reported for community college instructors in Oregon.

The review of literature begins with research on values in general. Research on work values and then relevant research pertaining to personal values is then reviewed,

\section{Values}

Many authors have written of values and defined them in many ways. Inlow (1972) said, "Values to me, simply stated, are the determiner in man that influence his choices in life and thus decide his behavior" (p. 2). In 1957, Super defined values as the "qualities which people desire and which they seek in the activities in which they engage, in the situations which they live, and in the objects they make or acquire" (p. 4). 
Gabriel (1974) stated:

Values are means, among others, by which behavior is regulated when several choices or courses of action are available to a person. But value implies more than just choice; it implies that certain standards have been accepted by an individual. (p. 62)

Rokeach (1973) stated:

Values are the cognitive representation not only of individual needs but also of societal and institutional demands. They are the joint results of sociological as well as psychological forces acting upon the individualsociological because society and its institutions socialize the individual for the common good to internalize shared conceptions of the desirable; psychological because individual motivations require cognitive expression, justification, and indeed exhortation in socially desirable terms. The cognitive representation of needs as values serves societal demands no less than individual needs - . Needs may or may not be denied, depending on whether they can stand conscious, personal, and social scrutiny, but values need never be denied. Thus, when a person tells us about his values he is surely also telling us about his needs. (p.20)

Gabriel (1964) in discussing teaching and values and how the two are intertwined, stated:

Teaching then is a human process. It is a social process. Consequently, teaching is not only a matter of lesson techniques, classroom organization, and administration. If this were all, it would be a relatively easy job. It is also one in which the teacher needs to understand himself and his pupils and how the relationships between them help or hinder the process of learning. (p. 89)

Many authors have discussed the general topic of values in teaching and how values are one of the important aspects that instructors bring to the front when they are in a classroom and how their own values and those of the student become strengthened. Combs, Blume, Newman, and Wass (1974) stated that teachers must "give students the opportunity to think, to decide, and to act on the basis of their own values. In the process of doing so these values will become 
strengthened, and the teacher will become stronger and more decisive" (p. 121). Pullias and Young (1968, p. xv) said: "We are convinced that teachers inevitably teach what they believe and what they do not believe. Hence, values play a great part in the discussion of teaching".

Values have been examined for many years by many educators, philosophers, and authors. The following two authors approached this topic from differing perspectives. Bateson (1944) briefly summarized one of the major assumptions underlying this variously phrased concept when he said: "The human individual is endlessly simplifying, organizing, and generalizing his own view of his own environment; he constantly imposes on this environment his own constructions and meanings" (p. 273). A more comprehensive statement was presented by KTuckholm (1957):

There is a philosophy behind the way of life of each individual and of every relatively homogeneous group at any given point in their histories. This gives, with varying degrees of explicitness or implicitness, some sense of coherence or unity both in cognitive and affective dimensions. Each personality gives to this philosophy an idiosyncratic coloring and creative individuals will markedly reshape it. However, the basic outlines of the fundamental values, existential propositions, and basic abstractions have only exceptionally been created out of the stuff of unique biological heredity and peculiar life experience. The underlying principles arise out of, or are limited by, the givens of biological human nature and the universalities of social interaction. The specific formulation is ordinarily a cultural product. In the immediate sense, it is from the life-ways which constitute the designs for living of their community or tribe or social-economic class or nation or civilization that most individuals derive their mental-feeling outlook. (p. 2)

Combs, Hvila \& Purkey (1971), Lepley (1957), and Rescher (1969), had much to say on the nature of values in people. All agreed that 
values are basic concepts that are ingrained in each individual, that an individual "becomes his beliefs" and that beliefs or values become an explanation of why individuals behave in given ways. Allport (1961) stated it as personal "values are the dominating force in $1 \mathrm{ife}$, and all a person's activity is directed toward the realization of his values" (p. 543).

Rokeach (1960, p. 336) wrote "An attitude or value is seen to be a stubborn thing, rooted in irrational motives and extremely difficult to change." Values are deeply rooted in people's makeup and they tend to have effects far beyond the immediate present.

Pugh (1977) stated:

The individual is motivated by a complex set of innate values. Some of the values serve the individual's physical welfare; others serve the welfare of society. As seen by the individual, some values correspond to his physical needs; others correspond to his social and psychological needs. The achievement of a satisfying life-style requires a degree of success in meeting all the innate needs - both the physical and psychological. (p. 124)

As each individual matures, the individual seems to take on characteristics of the society and familiar situations in which she (he) is found. Values are instilled at an early age and are subject to some change, but they seem to have such enduring characteristics that they will change only after much consideration on the part of the individual who wants or needs to change.

Fenner (1972) stated that values have the following characteristics.

1. They serve as judgement standards and criteria.

2. They result from and are constantly being reconstructed within the person by means of a dynamic process.

3. They seem to involve both needs of the individual and valuations of the culture. 
4. They tend to have abiding rather than transitory meaning to a person; and

5. They have generalized, inclusive, molar nature rather than specific, concrete, structured character. (p. 24)

From the before mentioned authors there seems to be a fair amount of consensus about the nature of values: (1) they seem to have abiding nature; (2) they affect behavior of each individual; (3) they are seen as standards that influence each individual; and (4) they are affected by society and family influences at an early age. These comprise the basic framework that apply to the nature of values.

\section{Work Values}

Some of the more notable research studies on work values were reported by Hales and Fenner (1972), Hales and Hartman (1978a,b), Hales and Yackee (1974), Holland (1966), and Super (1968).

Hartman (1977) stated: "The value system of an individual can be divided into subsystems, one of which is the work values system extension of an individual's value to the world of work" (p. 1).

Other authors have contributed to the theory of work values, including: Ginzberg, Ginsburg, Axelrad \& Herma (1951). They described the process of occupational decision making as occupying three distinct periods.

The period during which the individual makes what can be described as a fantasy choice; the period during which he is making a tentative choice; and the period when he makes a realistic choice. The first coincides in general with the latency period,.... the second coincides by and large with early and late adolescence; with few exceptions realistic choices are made in early adulthood. (p. 60)

Roe (1956) described his concept that occupational identity formed through the influence of a given set of early parent - child 
relationships. He said that "there is some indication that, the earlier the choice and the closer to personal or family preoccupations, the more likely it is to be established" (p. 265).

Super, Crites, Hummel, Moser, Overstreet \& Warnath (1957)

presented 11 propositions regarding vocational development. These included:

Proposition 1. Vocational development is an ongoing, continuous, and generally irreversible process. . .

Proposition 2. Vocational development is an orderly patterned process and thus predictable...

Proposition 3. Vocational development is a dynamic process of compromise or synthesis....

Proposition 4. Self-concepts begin to form prior to adolescence, become clearer in adolescence, and are translated into occupational terms in adolescence. . .

Proposition 5. Reality factors (the reality of personal) characteristics and the reality of society play an increasingly important part in occupational choice with increasing age, from early adolescence to adulthood....

Proposition 6. Identification with a parent or a parent substitute is related to the development of adequate roles, their consistent and harmonious interrelationship, and their interpretation in terms of vocational plans and eventualities. .

Proposition 7. The direction and rate of the vertical movement of an individual from one occupational level to another is related to his intelligence, parental social economic level, status need, values, interests, skill in inter personal relationships, and the supply and demand conditions in the economy. ...

Proposition 8. The occupational field which the individual enters is related to his interest and values, the identifications he makes with parental or substitute role models, the community resource he uses, the level and quality of his 
educational back ground, and the occupational

structure, trends, and attitudes of his

community. . .

Proposition 9. Although each occupation requires a

characteristic pattern of abilities, interests, and personality traits, the tolerances are wide enough to allow both some variety of individuals in each occupation and some diversity of occupations for each individual. . .

Proposition 10. Work satisfactions depend upon the extent to which the individual can find adequate outlets in his job for his abilities, interests, values, and personality traits....

Proposition 11. The degree of satisfaction the individual attains from his work is related to the degree to which he has been able to implement his self-concept in his work. (pp. 89-98)

Neff (1968) reported on Super's research approach. He stated that Super "can only be praised for his insistence that vocational behavior will be understood only when the secrets of individual development are revealed" (p. 106). Going further in his book, Neff made an analysis of the famous Hawthorne Study of the General Electric Company and expanded on Super's concept:

The Hawthorne studies have served the purpose of calling it to our attention that the human worker brings far more to his task than a variable ability to follow instructions and carry out prescribed movements. He also brings his momentary moods, as well as more enduring emotions and feelings, his social beliefs and attitudes, his entire personality. (p. 25)

Tiedeman (1963) is another author who studied work values. His theory uses the development of the vocational self-concept akin to that of Super. He stated: "Career development is conceived as the process of fashioning a vocational identity through differentiation and integration of the personality as one confronts the problem of work in living" (p. v). 
Holland (1973, p. 111) contributed a six occupational classification to the world of work of which values were an integral part. Realistic occupations include skilled trades, technical, and some service occupations. Investigative occupations includes scientific and some technical occupations. Artistic occupations include artistic, musical, and literacy occupations. Social occupations include educational and social welfare occupations. Enterprising occupations include managerial and sales occupations. Conventional occupations include office and clerical occupations.

It seems from this that the nature of values carries on into the workplace as well as in the other elements of human endeavor.

Waggoner (1983) wrote:

Research of the interaction between work and workers has been conducted for over half a century, originally focusing upon techniques concerned with personnel selection. . . . Personality theory can be related to the study of work values. One's occupation is a reflective of an individual's motivation, knowledge, personality and ability, and members of a vocation have similar personality traits and similar histories of personal development. . . . An individual's values are an expression of his needs. (p.36)

Work value studies have been suggested for many reasons. Many authors, including Roe (1956), reported on the concept of work values and managing employees. It was suggested that fundamental changes were going on in the workplace as the concept of the purely the economic man was being replaced by the thought that men also worked for reasons other than the money that they earned. Super (1957) remarked on the importance of work for each individual in terms of one's total life satisfaction. He stated:

Work satisfactions and life satisfactions depend upon the extent to which the individual finds adequate outlets for 
his abilities, interests, personality traits, and values;

they depend upon his establishment in a type of work, a work situation, and a way of life ir which he can play the kind of role which his growth and exploratory experiences have led him to consider congenial and appropriate. (p. 190)

\section{Measurement of Work Values}

Several researchers have developed instruments that measure work values. Miller's (1954) Work Values Inventory, Hammond's (1956)

Occupational Rating Scale, Stefflre's (1962) Work Values Inventory, Super's (1968) Work Values Inventory, and Hales and Fenner's (1973) Ohio Work Values Inventory are among those in use. The latter is the most recent and has been employed in a number of studies.

Selection of the constructs to be measured is one of the more important tasks that has to be done in the development of any research tool. The values measured by the Ohio Work Values Inventory (Hales and Fenner, 1973a) were selected after review of various constructs used in other studies. Fenner (1972), after researching many authors on work values, concluded that they "have tended to agree that six constructs comprise a base or core group of work values. . . near unanimity exists among scale developers regarding the inclusion of the following subscales in any measurement device: Money, Security, Independence, Altruism, Prestige, and Control" (p. 35). When defined as multifaceted, Self Realization is another scale that has agreement by many authors. All seven of the above mentioned scales are included in the OWVI. Additionally, four other scales are included in the OWVI that have appeared directly or indirectly in other instruments that measure work values. These scales and the number of instruments in which each scale 
appeared are: Task Satisfaction - 5, Ideas/Data - 2, Object

Orientation - 2, and Solitude - 2 (Fenner, 1972). With this

representation of scales, it may be said that the Ohio Work Values

Inventory is one of the more inclusive of instruments measuring work

values.

The 11 scales of the Ohio Work Values Inventory may be classified as intrinsic or extrinsic. Super (1957) stated: "Intrinsic values are those inherent in the work activity and extrinsic values are generally the rewards" (p. 299). According to Fenner (1972), values are classified as intrinsic if they can be realized by the mere doing of the work and extrinsic if their satisfaction is dependent upon factors consequent to or extrinsic to the work. Extrinsic values may be further classified according to situate values that require for their realization the presence or existence of particular conditions or work values that are rewards of work. The 11 scales of the OWVI may be categorized as follows according to Fenner (1972).

I. Intrinsic values

A. Altruism

B. Object Orientation

C. Self Realization

D. Task Satisfaction

E. Ideas/Data Orientation

II. Extrinsic values

A. Rewards of work

1. Control

2. Money

3. Prestige

4. Security

B. Situate

1. Independence

2. Solitude (p. 62)

The Ohio Work Values Inventory has been used in several research studies. Among them were studies of fifth-, eighth-, and eleventh-grade 
students in three Ohio public schools (Hales \& Fenner, 1972), by practicing nurses and nurses in training (A. K. Hales, 1977), sex of respondents (Hales \& Fenner, 1973b), relation of self-concept and sex of respondent (Hales \& Yackee, 1974), undergraduate students at Ohio University (Hales \& Hartman, 1978b), and the relationship between work values and personality of second-year students at two-year Ohio technical Colleges (Hales \& Hartman, 1978a).

In 1983, Klampe conducted a study to identify the work values of secondary school teachers in selected Oregon school districts to determine differences in work values by subject area taught, using the Ohio Work Values Inventory. All teachers in the sample, regardless of subject area, highly valued Task Satisfaction and Self Realization. In pair-wise mean comparisons, Math/Computer Science teachers placed less value on Self Realization than did the Business teachers. The data also indicated that female secondary teachers placed less value on Object Orientation, Solitude, and Prestige than did the males in the sample, and the female teachers placed greater value on Self Realization than did the males in the sample.

Waggoner (1983) researched the work values of metropolitan school administrators and found that there was a lack of statistically significant differences between the sexes on nine of the eleven work values which indicated male and female administrators held similar work values. Female administrators assigned more importance only to the work values of Self Realization and Ideas/Data Orientation. Central office administrators varied significantly from elementary school administrators on three key work values. Central office administrators 
assigned significantly more importance to the work values of

Independence and Prestige and less importance to Altrusim than did elementary school administrators in the Portland metropolitan area.

As indicated, the Ohio Work Values Inventory has been used extensively in several studies measuring work values of different populations. Also, the OWVI may be considered to be one of the more complete work value inventories, measuring a total of 11 work values.

\section{Personal Values}

The body of literature published on the topic of personal values is extensive. The topic has been studied and researched by numerous authors through the years.

Assumptions about the nature of values, five which were postulated by Rokeach (1973) and reported upon earlier in this paper, represent a set of reasons why values occupy a central position across all of the social sciences.

Dewey (1930) was one of the early educators who called attention to values within individuals. He stated:

Circumstances may change, but human nature remains the same from age to age. Heredity is more potent than environment and human heredity is untouched by human intent. . . Ways of belief, of expectation, of judgement and attendant emotional dispositions are not easily modified after they have once taken shape. (p. 107)

Inter-personal values generally take form in early life of each

individual. Several authors have reported on studies in this area.

Allport (1961) reported that:

Since the young child has few native resources for survival, it is, unlike other organisms, a completely dependent prisoner of its culture. . . The home 
situations, the language he learns, the school, the economic practices, and the prescription for eating, sleeping ... models for learning are all outside himself. Early he begins to learn the values of his culture. Many of them are taught repeatedly - at home, by the church and school, through newspapers, comics, on the radio and television. No child can escape the common heritage. A cultural value is a way of life deemed desirable by most members of society. (p. 169)

Lerner (1976) stated that values develop:

by exposure to a value situation. . . in early childhood. - . There are value agents, or actors in these value situations, whether at home, school, playground, or in the street. The exposures at the earliest age are like being thrown into the water: The value agents and models must help the child to swim. . . Internalizing. This is the process of making the value choice part of oneself, not necessarily in a conscious way, but in a deep internal way, so that it becomes a habitual and unreflecting - almost a reflexive way of meeting a situation. (pp. 108-111)

Dukes (1955) wrote that "The most conspicuous factor in the development of an individual's social value appears to be his home and family life" (p. 37). This evidence seems to indicate that personal values are inculcated into each individual early in life and form the basic tenets that the person will follow to some extent throughout his life.

Bills (1952) wrote:

Lecky, in his theory of personality postulated that values which have been accepted into the personality act as a barrier to the acceptance of new, opposing values. This opposition is necessary to insure for the individual a consistent value system which constitutes the core of his personality. (p. 217)

Bem (1970) said that "Every belief can be pushed back until it is seen to rest ultimately upon a basic belief in the credibility of one's own sensory experience or upon a basic belief in the credibility of some external authority" (p. 5). 
The basic values, although changeable somewhat in life, will be strong throughout a person's individual being and will tend to remain somewhat in the same general position that it assumed when the value took shape. Krech, Crutchfield, and Bollachey (1962) reported that "An attitude that stems from a value that is basic to the individual and strongly supported by his culture will be difficult to move in an incongruent direction" (p. 220). Bem (1970) stated: "Values are important because of their centrality to other beliefs and attitudes" (p. 17).

Values have a way of being transmitted from generation to generation and from member to member of a society. It seems that the values are passed on in many fashions. Another researcher, Gabriel (1974), looking at values in America, said:

Every society creates ideal images of what the behavior in thought and action should be. When taken together, these images express the vision of the good life that the people of society have achieved. These images, known and approved by the members of the society, give form to its values. A value is an ideal, a paradigm setting forth a desired and esteemed possible social reality. In essence, values are beliefs - beliefs that the idealized ways of living and acting are the best ways for the society. Because values are beliefs, they serve to inspire the members of society to act in the approved ways. Because values are ideal pictures, they provide a means of judging the quality of actual behavior. In this role they become standards. . . Institutions, such as the family and school, continually transmit values to oncoming generations. ( $p$. 149)

In a report on a study of values, Maddi (1980) said:

Personality is a stable set of characteristics and tendencies that determine those commonalities and differences in the psychological behavior (thoughts, feelings, and actions) of people that have continuity in time and that may not be easily understood as the sole result of social and biological pressures of the moment. (p. 10) 
Parker (1931) reported that "A value is always an experience, never a thing or object. Things may be valuable, but they are not values" (p. 211). Rescher (1969) went on, "A man's values are both clues to guide another's explanation of his actions and guides to his own deliberation in the endeavor to arrive at decision" (p. 29).

Other authors who have reported on many facets of values included Taylor (1928) who said that human values:

depend on us, on our sensations, perceptions, desires, estimates, and final judgements. They were in these functions of ours as part and parcel of their activities. . -. The human need to function realizes itself in the creation of values and the validities which support them. (p. 27)

Values are determined in many ways. Morris (1956) created a chart that appears to be quite relevant; it illustrates the relationship between a value and its determinants. He stated:

Data from four facets of life seem to be relevant. . . biological, psychological, social, and ecological determinants of values. . . Values do not merely have determinants but are themselves determinants that to varying degrees affect changes in all four other domains (pp. 67-68).

This may be illustrated in the following figure.

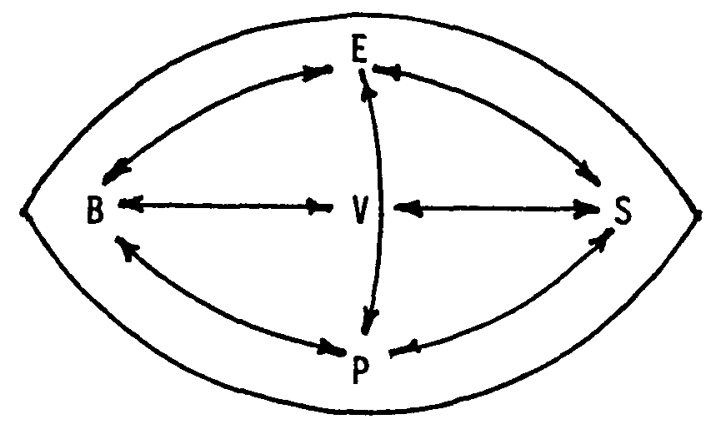

$V=$ The value field, $E, S, P$ and $B$ respectively signify ecological, social, psychological and biological determinants of value (Morris, 1956, p.68)

Figure 1. Determinants of a Value 
Thus it can be said that values are significant factors in the behavior of individuals.

Rokeach (1960) concurred in this when he said "I consider a value to be a type of belief, centrally located within one's total belief system, about how one ought or ought not to behave, or about some end-state of existence worth or not worth attaining" (p. 124).

\section{Value-Types of Individuals}

Allport (1961) drew the following inferences from Spranger's

\section{(1928) Types of Men.}

Spranger, somewhat in the manner of Morris, defines six major value-types. This author contends that every actua? person can be regarded as approaching (but not fitting perfectly within) one or more of these value-directions. Human life, it seems to Spranger harbors six main types of value, and these appeal in varying degrees to individuals who build the unity of their lives about them. . . . Spranger does not argue there are six main types of people, but six main types of values... a gauge by which we can tell how far a given person has gone in organizing his life by one or more of these basic schemes.

1. The theoretical. The dominant interest is the discovery of truth. Takes a cognitive attitude. . . necessarily an intellectualist. . . . chief aim in life is to order and to systematize his knowledge. ..

2. The economic. Economic man is characteristically interested in what is useful. . . . This type is thoroughly practical and conforms well to the prevailing conception of the average American businessman.

3. The esthetic. The esthetic man sees his highest value in form and harmony. . . . He need not be a creative artist; nor need he be effete; he is esthetic if but he finds his chief interest in the artistic episodes of life. 
4. The social. The highest value for this ideal type is love of people, whether one or many, whether conjugat, filial, friendly, or philanthropic. . . the social interest is selfless and tends to approach very closely to the religious attitude.

5. The religious. The highest value for the religious man may be called unity. He is mystical, and seeks to comprehend the cosmos as a whole, to relate himself to its embracing totality. . . one whose mental structure is permanently directed to the creation of the highest and absolutely satisfying value experience.

6. The political. The political man is interested primarily in power. His activities are not necessarily within the narrow field of politics. . . Leaders in any field generally have high power value. . . . certain personalities who wish above all else for personal power, influence, and renown.

One advantage of such portraits, even though they are too perfect in consistency to exist in real life, is that they lend themselves to measurement. (pp. 296-299)

\section{Values and Teaching}

Instructors on college campuses project their own system of values into their teaching as reported by Jacob (1957). When all instructors are classified under one of the six theoretical types of people as espoused by Spranger, then the values that they possess will have an influence on students by exerting their own value system into their teaching methodology. Jacob stated:

It is perhaps significant, however, that faculty identified as having this power with students are likely to be persons whose own value-commitments are firm and openly expressed, and who are out-going and warm in their personal relations with students. Furthermore, faculty influence appears more pronounced at institutions where association between faculty and students is normal and frequent, and students find teachers receptive to unhurried and relaxed conversations. (p. 35) 
Combs and Snygg (1959) also projected the idea of values as being an important aspect of teaching skills and of the teaching profession. They said that "Education, to be effective, must result in a change of behavior of the person educated" (p. 207).

They further stated:

Techniques of teaching are important, but in the last analysis, the techniques used by a teacher will be determined by his concept of himself, of his duties and students. . . No matter how thorough his training in skills and techniques of teaching, those skills and techniques will not be used if they do not conform to his personal philosophy of life and serve his immediate needs. (p. 243)

\section{Summary}

This review of the literature showed that values are instituted at an early age in each individual and that these values are generally adhered to throughout one's lifetime. Certainly, there may be slight changes, but the basic values seem to remain much the same. The literature concerning personal and work values was examined, including the determinants of values, demographic variables related to values, and the influence of the values of instructors on their teaching and relationships with students. 
CHAPTER III

GENERAL METHODOLOGICAL DESIGN

Three sets of data were gathered from instructors in selected teaching assignments at Oregon community colleges during the Spring of 1983. In order to explore relationships of these two groups of instructors, one set of data was collected using the Ohio Work Values Inventory, an instrument measuring work values, and one set of data was collected using the Rokeach Value Suryey, an instrument measuring personal values, and the last set of data was collected from a biographical questionnaire. (See Appendix A.)

The primary purpose of this study was to examine the work values and life values of Oregon community college faculty. Using teaching status (part-time/full-time), teaching assignment, and selected biographical characteristics as independent variables, the following question was investigated: Are there significant differences in the work and life (terminal, instrumental) values of instructors in Oregon community colleges? This chapter describes the design of the investigation, instrumentation, data gathering procedures, and the statistical design of the study.

\section{Design of the Investigation}

Since none of the independent variables investigated was active (manipulated), this is a descriptive study--a study of the personal and 
work values of part-time and full-time instructors in Oregon community colleges. The independent variables of the study were job status, job assignment, sex of instructor, number of years teaching, age of instructor, degree held by instructor, other job held/no other job held by instructor and teaching location of instructor. The dependent variables were: the eleven constructs of the Ohio Work Values Inventory (Altruism, Self Realization, Object Orientation, Security, Control, Independence, Money, Prestige, Task Satisfaction, Solitude, and Ideas/Data Orientation); the eighteen Rokeach Terminal Values (A Comfortable Life, An Exciting Life, A Sense of Accomplishment, A Horld at Peace, A World of Beauty, Equality, Family Security, Freedom, Health, Inner Harmony, Mature Love, National Security, Pleasure, Salvation, Self Respect, Social Recognition, True Friendship, and Wisdom); and the eighteen Rokeach Instrumental Values (Ambitious, Broadminded, Capable, Clean, Courageous, Forgiving, Helpful, Honest, Imaginative, Independent, Intellectual, Logical, Loving, Loyal, Obedient, Polite, Responsible, and Self Controlled).

\section{Sampling}

A11 community colleges in Oregon participated in this study. The faculty of each college was stratified by job status (part-time, full-time) and areas of instruction. The Oregon Community College Directory, which lists personnel employed by each community college, was used for the names and teaching assignments of full-time instructors and a liaison person from each community college was used for the names and 
teaching assignments of part-time instructors (there was no state-wide directory of part-time instructors).

The instructional areas were: Natural Science (Chemistry, Physics, Biology, Botany, Zoology, Geology, General Science, etc.), Social Science (Anthropology, Geography, Western Civilization, History, Psychology, Sociology, etc.), Mathematics (Arithmetic, Algebra, Geometry, Trigonometry, Statistics, Calculus, etc.), English (Composition, Literature, Reading, Shakespeare, etc.), Auto/Industrial Mechanics (Auto, Welding, Machine Shop, Diesel, Aircraft Mechanics, etc.), Business Education (Accounting, Business Mathematics, Management, Bookkeeping, Merchandising, etc.), Secretarial Science (Word Processing, Office Procedures, Business Communications, Typing, Shorthand, etc.), and Health Occupations (Nursing, Medical Office Assisting, Dental Assisting, X-Ray Technician, etc.).

A total of 1,736 full-time instructors and approximately 4,400 part-time instructors were available in the population of Oregon community college instructors. In determining the number of instructors to include in the sample, two variables were carefully considered: teaching area and teaching status. With eight teaching areas and two levels of teaching status (part-time, full-time), samples were needed for 16 cells, with a preferred minimum of 50 subjects per cell. To partially allow for sample shrinkage, an attempt was made to draw a sample of 65 per ce11, but lack of enough available samples in some cells resulted in an initial sample of 984 (vs. 1,120 ).

The sample was selected in such a manner as to obtain, within the limits imposed by available faculty, the same number of faculty from 
each instructional area, split equally between part-time and full-time faculty. Thus, the faculty of each instructional area was partitioned into part-time, full-time instructors. Within each cell (instructional area, teaching status), the faculty was identified by college to help ensure geographic representation; the proportion of faculty of each cell from each college was determined. Proportional (by college) random sampling was done within each cell to obtain the needed sample. In cells in which the total available sample was equal to or less than the desired sample, all instructors were included in the sample (total sampling).

\section{Instrumentation}

Two instruments were used in this study: the Ohio Work Values Inventory and the Rokeach Value Survey.

Ohio Work Values Inventory

The Ohio Work Values Inventory (OWVI) assesses the importance individuals attach to the qualities of work that are personally rewarding and fulfilling.

The maximum validity an instrument may obtain can be estimated by the square root of the reliability coefficient. The maximum validity of the OWVI has been estimated through a number of studies, including 4th-grade students, technical college students, nurses and school administrators (Hales, 1985).

Excluding the fourth-grade sample, the maximum validity estimates ranged from a low of .87 for nurses on Task Satisfaction to a high of .97 for school administrators on Money. For fourth-grade students, maximum validity coefficients ranged from a low of .84 on Solitude to a high 
of .93 on Money. Given the procedures used for scale and item selection, the coefficients obtained in this manner should provide reasonable estimates of the validity of the inventory. (p. 19).

The construct validity of the OWVI is supported by the measures used in devising this inventory and corroborates the various factor analytic studies (Hales, 1985). The two scales to show the greatest separation difficulty were Task Satisfaction and Self Realization. The tendency of the two scales was either to load as one factor or to mix their items on two factors. This is not without expectation for two reasons. First, both scales were designed to measure two aspects of Comb and Snygg (1959) Self Realization construct. Second, it would be expected that teachers, with a high sense of self, are introspective and oriented to intrinsic work values and would deem similar value on these two constructs.

The OWVI consists of 77 items that measure 11 significant work values. Each of the 77 items is designed to have a logical relationship with only one of the 11 work values. The respondent reports his or her intensity of valuing to each item by selecting one of five possible answers that represent points on a scale of "liking." The possible answers from which the respondent is to select are: Not much, A little, Fairly much, A lot, and Very much. Coefficient Alpha for each scale of the Ohio Work Values Inventory is presented in Table I (Hales \& Fenner, 1973a, p. 28). 
TABLE I

COEFFICIENT ALPHA FOR EACH OWVI SCALE

\begin{tabular}{lc}
\hline \multicolumn{1}{c}{ Scale } & Coefficient Alpha \\
\hline Altruism & .93 \\
Object Orientation & .90 \\
Security & .87 \\
Control & .91 \\
Self Realization & .82 \\
Independence & .85 \\
Money & .93 \\
Task Satisfaction & .78 \\
Solitude & .78 \\
Ideas/Data & .87 \\
Prestige & .90 \\
\hline
\end{tabular}

Table II (Hales \& Fenner, 1973, p. 30) provides the coefficient of correlation for each scale with each other scale of the OWVI. 
TAB!E II

OWVI SCALE CORRELATIONS

\begin{tabular}{|c|c|c|c|c|c|c|c|c|c|c|}
\hline Scale & Objo & $\mathrm{Sec}$ & Con & $S R$ & Ind & Mon & TS & Sol & $I / D$ & Pres \\
\hline Altruism & .13 & .14 & .09 & .28 & -.01 & .03 & .12 & -.18 & .30 & .30 \\
\hline \multicolumn{2}{|c|}{ Object Orient. } & .14 & .18 & .13 & -.03 & .08 & .02 & .17 & .14 & .04 \\
\hline \multicolumn{2}{|l|}{ Security } & & .22 & .31 & .32 & .29 & .37 & .06 & .05 & .14 \\
\hline \multicolumn{2}{|l|}{ Control } & & & .06 & .28 & .36 & .03 & -.12 & .00 & .33 \\
\hline \multicolumn{2}{|c|}{ Self Realization } & & & & .11 & .17 & .46 & -.03 & .30 & .25 \\
\hline \multicolumn{2}{|c|}{ Independence } & & & & & .37 & .26 & .18 & .07 & .18 \\
\hline \multicolumn{2}{|l|}{ Money } & & & & & & .17 & -.03 & -.07 & .45 \\
\hline \multicolumn{2}{|c|}{ Task Satisfaction } & & & & & & & .04 & .12 & .17 \\
\hline \multicolumn{2}{|l|}{ Solitude } & & & & & & & & .15 & -.14 \\
\hline \multicolumn{2}{|c|}{ Ideas/Data } & & & & & & & & & .19 \\
\hline
\end{tabular}

Rokeach Value Survey

The Rokeach Value Survey was designed to serve as an all-purpose instrument for research on human values.

Even though it is ordinal and ipsative, it is in many other respects an ideal instrument. It is simple in design and easy to administer to individuals and groups. . . . Nonetheless, the Value Survey is in every sense a projective test because it elicits response - rankings that come from internal demands rather than from external stimulus characteristics ... It can also be used in a purely empirical manner to describe similarities in and differences between any two groups one may happen to be interested in. (Rokeach, 1973, p. 51). 
Rokeach (1973, pp. 29-31) explained how the values were chosen in his book, The Nature of Human Values. The 18 terminal values were obtained from a number of different sources: a review of the literature mentioning various values, Rokeach's own terminal values, those obtained from 30 graduate students in psychology, and those obtained by interviewing a representative sample of 100 adults after explaining to them what terminal values were. The several hundred values that were obtained were reduced by eliminating those being judged to be more or less synonymous with one another, those which were empirically known to be more or less synonymous, those which overlapped, those which were judged to be too specific, and those which did not represent end-states of existence.

The 18 instrumental values were chosen very differently. The starting point was Anderson's (1968) list of 555 personality-trait words for which he had reported positive and negative evaluative ratings. Rokeach used only positive words, which reduced the list to about 200 words; and then he selected values from this reduced list by using only one word from a group of synonyms or near-synonyms, by retaining only those judged to be maximally different from or minimally intercorrelated with one another, by retaining only those judged to represent the most important values in American society, by retaining only those deemed to be maximally discriminating across social status, sex, race, age, religion, politics, etc., by retaining only those judged to be meaningful values in all cultures, and by retaining those one could readily admit to having without appearing to be immodest, vain, or boastful. Thereby, 18 values were chosen. 
The 18 values have a medium rank of 9.5 when the rankings are done in order, i.e., a ranking of 1 when stärting, a ranking of 2 , a ranking of 3, and down to a ranking of 18. George Miller (1956), in a research project, stated that the number of chunks of information that most people could keep in the immediate span of their attention was the number of seven, plus or minus two. The average length of the scale demanding the respondent's attention is 9.5 , a figure very close to seven - plus or minus two. The test-retest reliability coefficients for the Rokeach values are shown in Table III (Rokeach, 1973, p. 28).

Feather (1975) provided an insight into the reasons for using the Rokeach Value Survey in a research project of this type. His reasons are only echoed by mine. He stated:

Rokeach (1973) provides information about the Value Survey as an assessment procedure .... After using RVS in many studies . . . Rokeach concludes that the Value Survey emerges as a useful all-purpose instrument for research on human values with many positive advantages. (Feather includes results of reports in his book, author). Over the short term, test-retest reliabilities are of respectable magnitude; average value systems do not seem to depend upon the particular method (ranking) that the Value Survey employs; it seems to make little difference whether terminal values are ranked before instrumental values or vice versa -... and the value domain involved in the Value Survey appears to involve a fairly wide and heterogeneous sample of values not readily reducible to smaller sets (p. 154)

As Feather (1975) stated in his book, using these grounds he was encouraged to use the Value Survey as a basic instrument in his research program; and, that is the way this author would judge the RVS and its use, also. 
TABLE III

TEST-RETEST RELIABILITIES OF 18 TERMINAL AND 18 INSTRUMENTAL VALUES FORM D (GUMMED LABELS) - $(N=250)$

\begin{tabular}{|c|c|c|c|}
\hline Terminal Value & $r$ & Instrumental Value & $r$ \\
\hline $\begin{array}{l}\text { A Comfortable Life } \\
\text { (a prosperous life) }\end{array}$ & .70 & $\begin{array}{l}\text { Ambitious } \\
\text { (hard-working, aspiring) }\end{array}$ & .70 \\
\hline $\begin{array}{l}\text { An Exciting Life } \\
\text { (a stimulating, active life) }\end{array}$ & .73 & $\begin{array}{l}\text { Broadminded } \\
\text { (open-minded) }\end{array}$ & .57 \\
\hline $\begin{array}{l}\text { A Sense of Accomplishment } \\
\text { (lasting contribution) }\end{array}$ & .51 & $\begin{array}{l}\text { Capabie } \\
\text { (competent, effective) }\end{array}$ & .51 \\
\hline $\begin{array}{l}\text { A World at Peace } \\
\text { (free of war and conflict) }\end{array}$ & .67 & $\begin{array}{l}\text { Cheerful } \\
\text { (lighthearted, joyful) }\end{array}$ & .65 \\
\hline $\begin{array}{l}\text { A World of Beauty (beauty of } \\
\text { nature and the arts) }\end{array}$ & .66 & $\begin{array}{l}\text { Clean } \\
\quad \text { (neat, tidy) }\end{array}$ & .66 \\
\hline $\begin{array}{l}\text { Equality (brotherhood, } \\
\text { equal opportunity for all }\end{array}$ & .71 & $\begin{array}{l}\text { Courageous (standing } \\
\text { up for your beliefs }\end{array}$ & .52 \\
\hline $\begin{array}{l}\text { Family Security } \\
\text { (taking care of loved ones) }\end{array}$ & .64 & $\begin{array}{l}\text { Forgiving } \\
\text { willing to pardon others) }\end{array}$ & .62 \\
\hline $\begin{array}{l}\text { Freedom } \\
\quad \text { (independence, free choice) }\end{array}$ & .61 & $\begin{array}{l}\text { Helpful (working for } \\
\text { the welfare of others) }\end{array}$ & .66 \\
\hline $\begin{array}{l}\text { Happiness } \\
\text { (contentedness) }\end{array}$ & .62 & $\begin{array}{l}\text { Honest } \\
\quad \text { (sincere, truthful) }\end{array}$ & .62 \\
\hline $\begin{array}{l}\text { Inner Harmony (freedom from } \\
\text { inner conflict) }\end{array}$ & .65 & $\begin{array}{l}\text { Imaginative } \\
\text { (daring, creative) }\end{array}$ & .69 \\
\hline $\begin{array}{l}\text { Mature Love (sexual and } \\
\text { spiritual intimacy) }\end{array}$ & .68 & $\begin{array}{l}\text { Independent (self- } \\
\text { reliant, self-sufficient) }\end{array}$ & .60 \\
\hline $\begin{array}{l}\text { National Security } \\
\text { (protection from attack) }\end{array}$ & .67 & $\begin{array}{l}\text { Intellectual } \\
\quad \text { (intelligent, reflective) }\end{array}$ & .67 \\
\hline $\begin{array}{l}\text { Pleasure (an enjoyable, } \\
\text { leisurely life) }\end{array}$ & .57 & $\begin{array}{l}\text { Logical } \\
\quad(\text { consistent, rational) }\end{array}$ & .57 \\
\hline $\begin{array}{l}\text { Salvation } \\
\text { (saved, eternal life) }\end{array}$ & .88 & $\begin{array}{l}\text { Loving } \\
\quad \text { (affectionate, tender) }\end{array}$ & .65 \\
\hline $\begin{array}{l}\text { Self Respect } \\
\text { (self-esteem) }\end{array}$ & .58 & $\begin{array}{l}\text { Obedient } \\
\text { (dutiful, respectful) }\end{array}$ & .53 \\
\hline $\begin{array}{l}\text { Social Recognition } \\
\text { (respect, admiration) }\end{array}$ & .65 & $\begin{array}{l}\text { Polite (courteous, } \\
\text { well-mannered) }\end{array}$ & .53 \\
\hline $\begin{array}{l}\text { True Friendship } \\
\text { (close companionship) }\end{array}$ & .59 & $\begin{array}{l}\text { Responsible } \\
\quad \text { (dependable, reliable) }\end{array}$ & .45 \\
\hline $\begin{array}{l}\text { Hisdom (a mature } \\
\text { understanding of life) }\end{array}$ & .60 & $\begin{array}{l}\text { Self Controlled (restrained, } \\
\text { self-disciplined) }\end{array}$ & .52 \\
\hline
\end{tabular}

*For explanation of changes in values between forms $D \& G$, please see Appendix C. 
Data Gathering Procedures

The Oregon Community College Association was presented a proposal for this study and requested to provide an endorsement. This they did, with copies sent to all community college presidents. A written communication from the researcher was given to each community college president at a professional meeting in Salem on March 7, 1983. Each of the presidents agreed to participate in the study and to assign a contact person at the college to aid in identifying part-time faculty, distribute data-collection packets, and collect the packets. (Copies of these communications are found in Appendix B.)

Data-collection packets were prepared for distribution. Each packet included a letter of introduction, the Ohio Work Values Inventory, the Rokeach Value Survey, and a biographical questionnaire. (See Appendix A.) During the Spring of 1983, these packets were handdelivered or mailed to the individual designated at each college to coordinate data collection activities. (See Appendix B for the directions for dissemination and collection of packets.) 
The schools that distributed questionnaire packets after personal visitation by the researcher were: Portland Community College, Portland; Mt. Hood Community College, Gresham; Clatsop Community College, Astoria; Clackamas Community College, Oregon City; Chemeketa Community College, Salem; Linn-Benton Community College, Albany; Lane Community College, Eugene; Rogue Community College, Roseburg; and Umpqua Community College, Grants Pass. The other schools (Central Oregon Community College, Bend; Blue Mountain Community College, Pendleton; Treasure Valley Community College, Ontario; and Southwestern Community College, Coos Bay) were surveyed entirely through the mail.

All questionnaires were returned to the liaison person on each campus in a sealed pre-addressed envelope to insure confidentiality. From there the packets were returned to the researcher by mail or by personal visit to the campus.

\section{Statistical Design}

In this study, there were eight independent variables (job status, teaching assignment, sex of instructor, college location, teaching experience, highest degree held, age, and other employment) and three sets of dependent variables (11 work values, 18 terminal values, 18 instrumental values). In order to hold a .05 level of significance for each independent variable in the analysis of a dependent variable set, a multivariate analysis of variance was performed, followed by univariate analyses of the dependent variables only when the statistical hypothesis for the multivariate analysis was rejected. For independent variables with more than two levels, when the statistical hypothesis for the univariate analyses was rejected, a modified LSD (Least Significant 
Difference) test was performed on all pair-wise mean comparisons. (This test is appropriate for unequal samples, it is less strict than the Scheffe test in control of experiment-wise error rate, but more rigorous than the t-test and the LSD test. Scheffe suggests using a .10 leve] because of the strictness of his test.)

The correlation of each scale of the OWVI with each terminal and instrumental value was also calculated. For each coefficient, the probability of the value obtained occurring by chance when the population value is zero was calculated.

All analyses were performed using the Statistical Package for the Social Sciences, a Second Edition (Nie, Hul1, Jenkins, Steinbrenner, and Brent, 1975).

\section{Summary}

The research design was descriptive, since no variables were manipulated. The independent variables were from the biographical data collected. The dependent variables were the constructs of the Ohio Work Values Inventory and the terminal and instrumental values of the Rokeach Value Survey.

The initial sample included 984 Oregon community college instructors, partitioned by teaching assignment, geographic location, and teaching status. Respondents completed the Ohio Work Values Inventory, an instrument measuring their work values, the Rokeach Value Survey, an instrument measuring personal values, and a biographical data sheet. Data gathering procedures included disseminating the 
questionnaires through the community college campus mail system and return by same.

The statistical design included computing the means and standard deviations of the responses of the total sample on the Ohio Work Values Inventory and Rokeach Value Survey, as well as the means and standard deviations on specific sample sub-sets. A separate multivariate analysis of variance was performed, with alpha set at .05, (followed by univariate analyses of variance and Modified LSD tests, as appropriate), on levels of job status, teaching assignment, sex of instructor, college location, teaching experience, age, degree, and extra job/no extra job. The dependent variables were the scales of the OWVI, instrumental values, and terminal values. 
CHAPTER IV

PRESENTATION OF THE FINDINGS

This chapter presents the results of the research investigating the relationships between selected biographical characteristics and the work and personal values of community college instructors in Oregori, as measured by the Ohio Work Values Inventory and the Rokeach Value Survey. Sample characteristics, scoring procedures, and reliability and validity data are also reported.

Sample

The sample is described in terms of its size, college teaching status, job assignment, college teaching location, sex, age, degree, number of years teaching, number of respondents holding vocationa? certificates, other employment held and parental education.

Size

The initial sample contained 984 part-time and full-time instructors in Oregon community colleges in eight teaching categories. Those 984 included approximately equal numbers of part-time and full-time instructors from eight categories of instruction and from all college location categories. The response rate was $50.6 \%$ (See Table IV).

Job Status

Participants were asked to report their job status. The results indicated that 212 or $42.4 \%$ were full-time instructors, while 288 or 
$57.6 \%$ were part-time instructors (6 credits or less). Table $V$ summarized the job status of respondents.

TABLE IV

RETURN RATE OF QUESTIONNAIRES

\begin{tabular}{lcc}
\hline Type of Sample & Number & Response Rate \\
\hline Initiated Sample & 984 & \\
Responding Sample & 500 & $50.6 \%$ \\
\hline
\end{tabular}

TABLE V

JOB STATUS OF SAMPLE

\begin{tabular}{lcr}
\hline Status & $f$ & $\%$ \\
\hline Full-time & 212 & 42.4 \\
Part-time & 288 & 57.6 \\
\hline & 500 & 100.0 \\
\hline
\end{tabular}

Job Assignment

Each instructor was asked to list her (his) current teaching assignment in one of eight categories. The eight categories were essentially four categories of transfer education and four areas that comprised vocational education. 
As indicated in Table VI, the sample was distributed as follows: 9.8\% were Natural Science (Chemistry, Physics, Biology, Botany, Zoology, Geology, General Science, etc.) instructors; $12.6 \%$ were Social Science (Anthropology, Geography, Western Civilization, History, Psychology, Sociology, etc.) instructors; $12.4 \%$ were Mathematics (Arithmetic, Algebra, Geometry, Trigonometry, Statistics, Calculus, etc.) instructors; 12.0\% were English (Composition, Literature, Reading, Shakespeare, etc.) instructors; $10.0 \%$ were Auto/Industrial Mechanics (Auto, Welding, Machine Shop, Diesel, etc.) instructors; $9.4 \%$ were Secretarial Science (Word Processing, Office Procedures, Business Communications, Shorthand, Typing, etc.) instructors; $18.6 \%$ were

TABLE VI

CURRENT JOB ASSIGNMENT

\begin{tabular}{llr}
\hline \multicolumn{1}{c}{ Assignment } & $f$ & $\%$ \\
\hline Natural Science & 49 & 9.8 \\
Mathematics & 62 & 12.4 \\
Social Science & 63 & 12.6 \\
English Composition & 60 & 12.0 \\
Auto/Industrial Mechanics. & 50 & 10.0 \\
Secretarial Science & 47 & 9.4 \\
Business Education & 93 & 18.6 \\
Health Occupation & 76 & 15.2 \\
\hline Total & 500 & 100.0 \\
\hline
\end{tabular}


Business Education (Accounting, Business Mathematics, Management, Bookkeeping, Merchandising, etc.) instructors; and $15.2 \%$ were Health Occupations (Nursing, Medical Office Assisting, Dental Assisting, X-Ray Technicians, etc.) instructors.

Geographic Location

Each respondent was asked to indicate the location of the community college they were teaching in. These were divided into three categories: Metro, Other Urban, and Small City/Rural. The Metro community colleges were: Portland Community College, Portland; Mt. Hood Community College, Gresham; and Clackamas Community College, Oregon City. Other Urban were: Chemeketa Community College, Salem; Linn-Benton Community College, Albany; and Lane Community College, Eugene. Small City/Rural community colleges were: Blue Mountain Community College, Pendleton; Central Oregon Community College, Bend; Clatsop Community College, Astoria; Rogue Community College, Grants Pass; Southwestern Oregon Community College, Coos Bay; Treasure Valley Community College, Ontario; and Umpqua Community College, Roseburg. of those answering, $35.0 \%$ were Metro instructors, $33.0 \%$ were Other Urban, and $32.0 \%$ were Small City/Rural. Table VII gives frequencies and percentages.

$\underline{\text { Sex }}$

Participants were asked to indicate their sex. The results indicated that $46.0 \%$ were female and $54.0 \%$ were male. Table VIII summarizes the distribution of female and male respondents. 
TABLE VII

GEOGRAPHIC DISTRIBUTION OF SAMPLE

\begin{tabular}{llr}
\hline Location & $f$ & $\%$ \\
\hline Metro & 175 & 35.0 \\
Other Urban & 165 & 33.0 \\
Small City/Rural & 160 & 32.0 \\
\hline Total & 500 & 100.0 \\
\hline
\end{tabular}

TABLE VIII

SEX OF SAMPLE

\begin{tabular}{lcr}
\hline Sex & $f$ & $\%$ \\
\hline Female & 227 & 46.0 \\
Male & 267 & 54.0 \\
\hline Total* & 494 & 100.0 \\
\hline
\end{tabular}

*Six instructors did not answer this question.

Age

Ages of respondents were recoded into four categories for purposes of statistical analysis. As can be seen in Table IX, 23.0\% of the instructors were 50 years of age or over, $29.8 \%$ were from $40-49$ years of age inclusive, $38.9 \%$ were from 30-39 years of age inclusive, and only $8.2 \%$ were below 30 years of age. 
TARLE IX

AGE OF SAMPLE

\begin{tabular}{lcl}
\hline \multicolumn{1}{c}{ Age } & $f$ & $\%$ \\
\hline 50 and over & 112 & 23.0 \\
$40-49$ inclusive & 145 & 29.8 \\
$30-39$ inclusive & 189 & 38.9 \\
Below 30 & 40 & 8.2 \\
\hline Tota 1* & 486 & 100.0 \\
\hline
\end{tabular}

*14 Instructors did not answer the question.

Degree

The respondents were asked to indicate the highest degree each of them had earned. These were categorized as Doctorate, Master's, Bachelor, Associate, or Other. From the distribution presented in Table $X$, it is evident that the largest percentage, 66.5\%, hold Master's degrees, with all other categories totaling $34.5 \%$. 
TABLE $X$

HIGHEST DEGREE HELD

\begin{tabular}{lcr}
\hline Degree & $f$ & $\%$ \\
\hline Doctorate & 38 & 7.7 \\
Master's & 328 & 66.5 \\
Bachelor's & 83 & 16.8 \\
Associate & 38 & 7.7 \\
Other & 6 & 1.2 \\
\hline Total* & 493 & 100.0 \\
\hline
\end{tabular}

*A totai of seven respondents did not answer the question.

Number of Years Teaching

Individuals were asked to respond to number of years of teaching experience. Table XI indicates that over one-half of the instructors had between five and 14 years of experience.

Number of Respondents Holding Vocational Certificates

Individuals were asked whether they held a vocational certificate or not. Table XII shows that of the respondents, 83 or $16.6 \%$ held a vocational certificate while 417 or $83.4 \%$ did not. 


\section{TABLE XI}

YEARS OF TEACHING EXPERIENCE

\begin{tabular}{|c|c|c|}
\hline Years & $f$ & $\%$ \\
\hline Over 20 & 72 & 14.4 \\
\hline $15-19$ & 73 & 14.6 \\
\hline $10-14$ & 114 & 22.8 \\
\hline $5-9$ & 148 & 29.6 \\
\hline $0-4$ & 93 & 18.6 \\
\hline \multirow[t]{2}{*}{ Total } & 500 & 100.0 \\
\hline & Median 9.89 & \\
\hline
\end{tabular}

TABLE XII

NUMBER AND PERCENTAGES OF RESPONDENTS WITH VOCATIONAL CERTIFICATES

\begin{tabular}{crr}
\hline Certificate Held & $f$ & $\%$ \\
\hline Yes & 83 & 16.6 \\
No & 417 & 83.4 \\
\hline Total & 500 & 100.0 \\
\hline
\end{tabular}


Other Employment Held

The respondents were asked if they held another job and, if so, the job title (See Table XIII.) Many part-time instructors held no full-time job while some full-time instructors held outside employment.

TABLE XIII

OTHER EMPLOYMENT AND TYPE OF POSITION HELD

\begin{tabular}{|c|c|c|}
\hline Category & $f$ & $q$ \\
\hline & Other Employment & \\
\hline Yes & 189 & 62.0 \\
\hline No & 309 & 38.0 \\
\hline \multirow[t]{2}{*}{ Total } & 498 & 100.0 \\
\hline & Job Title & \\
\hline Education & 56 & 28.7 \\
\hline Health & 26 & 13.3 \\
\hline Business & 82 & 42.1 \\
\hline Mechanical & 10 & 5.1 \\
\hline Agriculture & 3 & 1.5 \\
\hline Other & 18 & 9.2 \\
\hline Tota 1* & 195 & 100.0 \\
\hline
\end{tabular}

*It would appear that four to six respondents gave job titles, but indicated no other job held. 
Parental Education

The respondents were asked to indicate years of education of parents. Table XIV summarizes this category.

The Table indicated that most of the parents of the community college instructor have at least a high school education; the range of education of the mother was from 4 years to 21 years of education and that of the father was from 3 years to 22 years of education.

Community College Location And Selected Biographical Characteristics

Years of teaching, highest degree held, vocational certificate held, and job title of other employment were examined for geographical differences. The years of teaching within the three geographic areas is shown in Table XV. The statistical hypothesis that geographic location and teaching experience are independent was rejected at the .05 level $\left.X^{2}=21.54 ; \mathrm{q}=.006\right)$. The assumption of this test of independence is that the frequencies within each category of years are equally distributed across the categories of geographic location within the population.

The table indicates that instructors with more teaching experience tended to be located in the metro area, those with intermediate experience tended to be in the Urban area, and those with somewhat less teaching experience were in the Small City/Rural areas. 
TABLE XIV

PARENTAL EDUCATION IN YEARS

\begin{tabular}{|c|c|c|c|c|}
\hline \multirow[t]{2}{*}{ Years } & \multicolumn{2}{|c|}{ Mother } & \multicolumn{2}{|c|}{ Father } \\
\hline & $f$ & $\operatorname{Adj} \%$ & $f$ & $\operatorname{Adj} \%$ \\
\hline $\begin{array}{r}22 \\
21 \\
20 \\
19 \\
18 \\
17 \\
16 \\
15 \\
14 \\
13 \\
12 \\
11 \\
10 \\
9 \\
8 \\
7 \\
6 \\
5 \\
4 \\
3\end{array}$ & $\begin{array}{r}0 \\
1 \\
3 \\
2 \\
15 \\
6 \\
63 \\
10 \\
50 \\
29 \\
213 \\
10 \\
19 \\
4 \\
44 \\
5 \\
5 \\
3 \\
3 \\
0\end{array}$ & $\begin{array}{r}0 \\
0 \\
1 \\
0 \\
3 \\
1 \\
13 \\
2 \\
10 \\
6 \\
44 \\
2 \\
4 \\
1 \\
9 \\
1 \\
1 \\
1 \\
1 \\
0\end{array}$ & $\begin{array}{r}1 \\
2 \\
11 \\
7 \\
15 \\
16 \\
61 \\
10 \\
40 \\
18 \\
155 \\
8 \\
26 \\
6 \\
68 \\
9 \\
14 \\
5 \\
5 \\
3\end{array}$ & $\begin{array}{r}0 \\
0 \\
2 \\
1 \\
3 \\
3 \\
13 \\
2 \\
8 \\
4 \\
32 \\
2 \\
5 \\
1 \\
14 \\
2 \\
3 \\
1 \\
1 \\
1\end{array}$ \\
\hline Mean & \multicolumn{2}{|c|}{12.54} & \multicolumn{2}{|c|}{12.38} \\
\hline Median & \multicolumn{2}{|c|}{12.20} & \multicolumn{2}{|c|}{12.13} \\
\hline Standard Deviation & \multicolumn{2}{|c|}{2.90} & \multicolumn{2}{|c|}{4.02} \\
\hline Range & \multicolumn{2}{|c|}{18.00} & \multicolumn{2}{|c|}{20.00} \\
\hline
\end{tabular}


TABLE XV

YEARS TEACHING BY GEOGRAPHIC LOCATION OF COMMUNITY COLLEGE EMPLOYMENT

\begin{tabular}{|c|c|c|c|c|c|c|}
\hline \multirow[t]{2}{*}{ Years } & \multicolumn{2}{|c|}{ Metro } & \multicolumn{2}{|c|}{ Other Urban } & \multicolumn{2}{|c|}{ Small City/Rural } \\
\hline & & $\left(\begin{array}{l}q \\
0\end{array}\right)$ & $f$ & $(\%)$ & $f$ & $(\%)$ \\
\hline Over 19 & & $(17.3)$ & 16 & $(9.9)$ & 19 & (11.9) \\
\hline $15-19$ & & $(17.3)$ & 15 & $(9.3)$ & 28 & $(17.6)$ \\
\hline $10-14$ & & $(22.5)$ & 41 & $(25.5)$ & 34 & $(21.4)$ \\
\hline $5-9$ & & $(28.9)$ & 61 & $(37.9)$ & 37 & (23.3) \\
\hline \multirow[t]{2}{*}{ Under 5} & & (13.9) & 28 & $(17.4)$ & 41 & $(25.8)$ \\
\hline & 173 & $(100.0)$ & 161 & $(100.0)$ & 189 & $(100.0)$ \\
\hline \multicolumn{3}{|c|}{$\begin{array}{l}\text { Calculated chi square } \\
\text { Probability with } 8 \text { df }\end{array}$} & & $\begin{array}{l}21.53820 \\
.00580^{*}\end{array}$ & & \\
\hline
\end{tabular}

*Statistical hypothesis was rejected at the .05 level of significance.

The distribution of highest degree held for each geographic location is shown in Table XVI. The statistical hypothesis that highest degree held is independent of geographic location was not rejected at the .05 level $\left(X^{2}=2.67 ; \mathrm{p}=.953\right)$. 
TABLE XVI

HIGHEST DEGREE HELD BY GEOGRAPHIC LOCATION OF COMMUNITY COLLEGE EMPLOYMENT

\begin{tabular}{|c|c|c|c|c|c|c|}
\hline \multirow[t]{2}{*}{ Degree } & \multicolumn{2}{|c|}{ Metro } & \multicolumn{2}{|c|}{ Other Urban } & \multicolumn{2}{|c|}{ Small City/Rural } \\
\hline & $f$ & $(\%)$ & $f$ & $(\%)$ & $f$ & $(q)$ \\
\hline Doctorate & 10 & $(5.8)$ & 14 & $(8.5)$ & 14 & $(8.9)$ \\
\hline Master's & 120 & $(69.8)$ & 108 & (65.9) & 100 & $(63.7)$ \\
\hline Bachelor's & 26 & $(15.1)$ & 27 & $(16.5)$ & 30 & (19.1) \\
\hline Associate & 14 & $(8.1)$ & 13 & $(7.9)$ & 11 & $(7.0)$ \\
\hline \multirow[t]{2}{*}{ Other } & 2 & $(1.2)$ & 2 & $(1.2)$ & 2 & $(1.3)$ \\
\hline & 172 & $(100.0)$ & 164 & $(100.0)$ & 157 & $(100.0)$ \\
\hline \multicolumn{3}{|c|}{ Calculated chi square } & $=$ & 2.67393 & & \\
\hline \multicolumn{3}{|c|}{ Significance with $8 \mathrm{df}$} & $=$ & .95310 & & \\
\hline
\end{tabular}

The table shows that the degrees held by instructors do not vary significantly as to the geographic area in which they teach. Percentages appear to be relatively stable among all geographic areas.

The distribution of vocational certificates held for each geographic location is shown in Table XVII. The statistical hypothesis that vocational certificate held is independent of geographic location was not rejected $\chi^{2}=0.987 ; \mathrm{p}=.611$ ). The assumption of the statistical hypothesis is that the subpopulation proportion of faculty holding certificates will be equal for all geographic locations. 
TABLE XVII

VOCATIONAL CERTIFICATE HELD BY GEOGRAPHIC LOCATION OF COMMUNITY COLLEGE EMPLOYMENT

\begin{tabular}{|c|c|c|c|c|c|c|}
\hline \multirow[t]{2}{*}{ Certificate Held } & \multicolumn{2}{|c|}{ Metro } & \multicolumn{2}{|c|}{ Other Urban } & \multicolumn{2}{|c|}{ Small City/Rural } \\
\hline & $f$ & $(\%)$ & $f$ & $(\%)$ & $f$ & $\left(\begin{array}{l}\alpha \\
0\end{array}\right)$ \\
\hline Yes & 33 & $(18.9)$ & 26 & $(15.8)$ & 24 & $(15.1)$ \\
\hline No & 142 & $(81.9)$ & 139 & $(84.2)$ & 135 & $(84.9)$ \\
\hline \multicolumn{3}{|c|}{ Calculated chi square } & \multicolumn{2}{|c|}{0.98695} & & \\
\hline \multicolumn{3}{|c|}{ Significance with 2 df } & \multicolumn{2}{|c|}{0.61050} & & \\
\hline
\end{tabular}

The table indicates that the percentages of vocational certificates held by instructors are similar across teaching locations (Metro, 0ther Urban, or Small City/Rural).

The distribution of job title of other employment for each geographic location is shown in Table XVIII. The statistical hypothesis that job title of other employment is independent of geographic location was rejected at the .05 level $\chi^{2}=24.186 ; \mathrm{p}<.001$ ). The job titles of positions other than community college held by faculty is related to geographic location. Those working in the metropolitan area tended to have more other jobs in education than did those in other geographic regions, whereas those working in other urban centers and in small city/rural areas tended to have more jobs in business than did those in the metropolitan area. 
TABLE XYII!

JOB TITLE OF OTHER EMPLOYMENT HELD BY GEOGRAPHIC LOCATION

\begin{tabular}{|c|c|c|c|c|c|c|c|}
\hline \multirow[t]{2}{*}{ Job Title } & \multicolumn{2}{|c|}{ Metro } & & \multicolumn{2}{|c|}{ Other Urban } & \multicolumn{2}{|c|}{ Small City/Rural } \\
\hline & $f$ & $(\%)$ & & $f$ & $(\%)$ & $f$ & $(\%)$ \\
\hline Health & 7 & $(9.4)$ & & 5 & $(7.4)$ & 14 & $(24.0)$ \\
\hline Business & 21 & $(28.4)$ & & 37 & $(55.2)$ & 24 & $(44.4)$ \\
\hline Education & 31 & $(41.9)$ & & 15 & $(22.1)$ & 10 & $(18.5)$ \\
\hline \multirow[t]{2}{*}{ Other } & 15 & $(20.3)$ & & 10 & $(14.9)$ & 6 & $(11.1)$ \\
\hline & 74 & $(100.0)$ & & 67 & $(100.0)$ & 54 & $(100.0)$ \\
\hline \multicolumn{3}{|c|}{ Calculated chi square } & $=$ & \multicolumn{2}{|c|}{24.18601} & & \\
\hline \multicolumn{3}{|c|}{ Significance with $6 \mathrm{df}$} & $<$ & & $.001 *$ & & \\
\hline
\end{tabular}

*The Statistical hypothesis was rejected at the .05 level of confidence.

\section{OWVI Descriptive Statistics}

The procedures used in scoring the inventory, scale means and standard deviations, and selected measurement characteristics of the inventory are discussed in this section.

Scoring of the OWVI

The Ohio Work Values Inventory (OWVI) consists of 77 items, divided equally among the 11 scales of Altruism, Self Realization, Object Orientation, Security, Control, Independence, Money, Prestige, 
Task Satisfaction, Solitude, and Ideas/Data Orientation. Table XIX indicates the assignment of the OWVI items to the scales.

TABLE XIX

ASSIGNMENT OF OWVI ITEMS TO SCALES

\begin{tabular}{lccccccc}
\hline \multicolumn{1}{c}{ Scale } & \multicolumn{7}{c}{ Items } \\
\hline Altruism & 1, & 12, & 23, & 34, & 45, & 56, & 67 \\
Object Orientation & 2, & 13, & 24, & 35, & 46, & 57, & 68 \\
Security & 3, & 14, & 25, & 36, & 47, & 58, & 69 \\
Control & 4, & 15, & 26, & 37, & 48, & 59, & 70 \\
Self Realization & 5, & 16, & 27, & 38, & 49, & 60, & 71 \\
Independence & 6, & 17, & 28, & 39, & 50, & 61, & 72 \\
Money & 7, & 18, & 29, & 40, & 51, & 62, & 73 \\
Task Satisfaction & 8, & 19, & 30, & 41, & 52, & 63, & 74 \\
Solitude & 9, & 20, & 31, & 42, & 53, & 64, & 75 \\
Ideas/Data & 10, & 21, & 32, & 43, & 54, & 65, & 76 \\
Prestige & 11, & 22, & 33, & 44, & 55, & 66, & 77 \\
\hline
\end{tabular}

Respondents were asked to read each statement in the OWVI and decide how strongly they felt about the statement. Respondents were asked to mark an " $x$ " on the line corresponding best to their opinion. For each question, one of the following responses was to be chosen: Not much, A little, Fairly much, A lot, or Very much. The items were scored one to five, in the aforementioned order. Each scale is represented by 
seven items. Therefore, the maximum possible score on each scale is 35 , and the lowest possible score on each scale is seven. The scales were designed such that higher scores correspond with stronger preference for the work value being scored.

Summary of the Scores

The means for each scale of the OWVI ranged from 18.67 for the Solitude scale to 31.33 for the scale of Task Satisfaction. The standard deviations of the 11 scales ranged from 3.99 for the scale of Self Realization to 7.04 for the scale of Money. Table XX summarizes these statistics in more detail.

Altruism. The construct of Altruism signifies the importance given to the opportunity for involvement with other people in a helping, supportive or service role. A quality of interpersonal giving by the valuer characterizes the relationships that are developed in the work. A higher score on this scale indicates that the individual attaches greater importance to involvement with other people in a helping, supportive or service role.

The mean score for the the Altruism scale was 27.44 , indicating respondents assigned considerable importance to the value of Altruism. The standard deviation was 5.33 . 
TAB!E XX

MEANS AND STANDARD DEVIATIONS AND FOR OWVI SCALES

\begin{tabular}{lll}
\hline \multicolumn{1}{c}{ Scale } & Mean & Standard Deviation \\
\hline Altruism & 27.44 & 5.33 \\
Object Orientation & 19.16 & 6.83 \\
Security & 24.68 & 6.54 \\
Control & 20.95 & 6.47 \\
Self Realization & 30.64 & 3.99 \\
Independence & 27.19 & 4.69 \\
Money & 23.48 & 7.04 \\
Task Satisfaction & 31.33 & 4.31 \\
Solitude & 18.67 & 5.67 \\
Ideas/Data & 27.81 & 4.68 \\
Prestige & 19.03 & 6.37 \\
\hline
\end{tabular}

Object Orientation. The construct of Object Orientation expresses the valuation of handling, tending or manipulating physical objects, such as utensils, materials, tools or apparatus. The value relates to work that involves making, fixing, operating, or changing the appearance of things. A higher score for the Object Orientation scale indicates that the individual assigns greater importance to handling, tending, or manipulating physical objects. 
The mean score on the Object Orientation scale was 19.16, indicating respondents assigned moderate importance to this value. The standard deviation was 6.83 on the scale.

Security. The construct of Security measures the desire for work that is steady and dependable, immune to unpredictable layoff or dismissal. A high score reflects that the individual assigns greater importance to possessing a steady, dependable position.

The mean of the Security scale was 24.68, indicating respondents assigned considerable importance to this value. The standard deviation was 6.54 .

Control. The construct of Control indicates the importance that an individual assigns to having the opportunity to take a leadership role or responsibility for other workers in the conduct of their work. This construct measures the value one has for a job in which the individual has an influencing or decision-making role with regard to the planning, supervision, and evaluation of workers. A higher score indicates that the individual wants leadership role or responsibility for other workers.

The mean of the Control scale was 20.95, indicating respondents assigned moderate importance to the value of Control. The standard deviation was 6.47 .

Self Realization. The construct of Self Realization expresses a preference toward work that permits the individual to utilize one's skills, abilities, and talents. The work allows for continued personal growth and realization of one's potential. A higher score indicates 
that the respondent wants a job that permits one to utilize one's skills, abilities, and talents.

The mean on the Self Realization scale was 30.64 , indicating respondents assigned great importance to realizing one's potential. The standard deviation was 3.99 .

Independence. The construct of Independence signifies the importance one assigns to work allowing one to determine working conditions. A higher score on this scale indicates that the individual prefers to be free from close supervision and wishes to structure the individual's own hours and working methods.

The mean on the Independence scale was 27.19 , indicating respondents assigned considerable importance to Independence in their jobs. The standard deviation was 4.69 .

Money. The scale of Money measures the importance that an individual assigns to a position that enables one to have a substantial income more than enough to assure the basic needs of life. A higher score indicates that the respondent values a position in which one can earn a substantial income.

The mean score for the Money scale was 23.48, indicating respondents assigned moderate importance to this work value. The standard deviation was 7.04 .

Task Satisfaction. The scale of Task Satisfaction measures the importance the individual assigns to work that generally is interesting and enjoyable. The individual, for the most part, performs work tasks he or she may look forward to doing. A higher score on this scale 
indicates that the respondent values a job that is interesting and enjoyable.

The mean for the Task Satisfaction scale was 31.33 , indicating respondents assigned great importance to Task Satisfaction in their jobs. This mean was the highest of all the work values. The standard deviation was 4.31 .

Solitude. The construct of Solitude is related to the preference for work situations characterized by the absence of close relationships with other people. The work can be done largely by one person, and it usually affords either few or brief structured personal encounters. A higher score on this scale reflects the desire for work that is done in relative isolation or solitude.

The mean for the Solitude scale was 18.67 , the lowest of all scale means. This indicates respondents assigned moderate importance to work done in relative isolation or solitude. The standard deviation was 5.67 .

Ideas/Data. The measures on the Ideas/Data scale indicated the importance one gives to having an opportunity to work with facts and ideas. A high score on this scale signifies a preference for dealing with, making sense out of, creating, and communicating ideas.

The mean of the Ideas/Data scale was 27.81 , indicating respondents assigned considerable importance to this work value. The standard deviation was 4.68 .

Prestige. The scale of Prestige measures the desire for work that will bring a person recognition. An aspect of this value is the opportunity 
to meet and associate with important people. A higher score on this scale signifies a preference for having a job that brings recognition and allows one to meet or associate with important people.

The mean on the Prestige scale was 19.03 , indicating respondents assigned moderate importance to this value. The standard deviation was 6.37 .

Measurement Characteristics of the OWVI

Measurement characteristics of the Ohio Work Values Inventory (OWVI), the instrument used to measure instructor work values, will be presented in the following section. Although the intent of this research was not to measure the reliability and validity of the instrument employed, analyses of reliability data for the sample is useful in interpreting the data from this investigation.

The reliability of the Ohio Work Values Inventory was measured using coefficient alpha to determine the degree of internal consistency among the questions concerning a particular work value. That is, coefficient alpha was calculated to determine the extent to which the pool of items chosen to measure each of the 11 constructs of the OWVI accurately represents the total pool of hypothetical items that could be used to measure the constructs of Altruism, Object Orientation, Security, Control, Self Realization, Independence, Money, Task Satisfaction, Solitude, Ideas/Data, and Prestige.

The internal consistency of the items for each of the 11 OWVI scales are presented in Table XXI. Reliabilities for the scales ranged from .821 to .930 , indicating a reasonable degree of internal consistency for the items on the OWVI; the median was .883 . 
TABLE XXI

COEFFICIENT ALPHA FOR EACH SCALE ON THE OWVI

\begin{tabular}{lc}
\hline \multicolumn{1}{c}{ Scale } & Coefficient Alpha \\
\hline Altruism & .883 \\
Object Orientation & .894 \\
Security & .918 \\
Control & .904 \\
Self Realization & .836 \\
Independence & .821 \\
Money & .930 \\
Task Satisfaction & .870 \\
Solitude & .827 \\
Ideas/Data & .832 \\
Prestige & .892 \\
\hline
\end{tabular}

The coefficient of correlation of each scale with each other scale was calculated, and these coefficients are presented in Table XXII. The scale intercorrelations ranged from .77 (Self Realization with Task Satisfaction) to -.27 (Altruism with Solitude), with a median value of approximately .18 . 
TABLE XXII

SCALE INTERCORRELATIONS OF THE OWVI

\begin{tabular}{|c|c|c|c|c|c|c|c|c|c|c|}
\hline Scale & Objo & $\mathrm{Sec}$ & Con & SR & Ind & Mon & TS & Sol & $I / D$ & Pres \\
\hline Altruism & .01 & .26 & .09 & .46 & .10 & .09 & .41 & -.27 & .28 & .21 \\
\hline \multicolumn{2}{|c|}{ Object Orientation } & .13 & .23 & -.09 & .05 & .19 & -.19 & .29 & .05 & .25 \\
\hline \multicolumn{2}{|l|}{ Security } & & .24 & .26 & .30 & .38 & .19 & .10 & .09 & .21 \\
\hline \multicolumn{2}{|l|}{ Control } & & & .06 & .16 & .32 & -.08 & .09 & .02 & .51 \\
\hline \multicolumn{2}{|c|}{ Self Realization } & & & & .46 & .16 & .77 & -.15 & .51 & .01 \\
\hline \multicolumn{2}{|c|}{ Independence } & & & & & .45 & .43 & .30 & .37 & .22 \\
\hline \multicolumn{2}{|l|}{ Money } & & & & & & .15 & .18 & .03 & .40 \\
\hline \multicolumn{2}{|c|}{ Task Satisfaction } & & & & & & & -.17 & .47 & -.07 \\
\hline \multicolumn{2}{|l|}{ Solitude } & & & & & & & & .12 & .16 \\
\hline \multicolumn{2}{|c|}{ Ideas/Data } & & & & & & & & & .09 \\
\hline
\end{tabular}

Summary

The scoring procedures and scale definitions were reviewed. Means, standard deviations, and reliabilities for all scales were reported. The work value of Task Satisfaction had the highest mean for the sample, indicating respondents assigned great importance to work that is interesting and enjoyable. The work value of Solitude had the lowest mean of all values measured, indicating that the respondents gave little importance to a job in which the instructor had few or brief structured encounters with other individuals. Instructors did not highly value work situations characterized by the absence of close 
relationships with other people. Internal consistency reliability coefficient (Alpha) ranged from .82 for Independence to .93 for Money.

Self Realization and Task Satisfaction were valued in the "great" range of values. Instructors in the sample highly valued work permitting one to utilize one's skills, abilities, or talents, thereby providing the opportunity for continued personal growth and realization of the instructor's full potential. They similarly valued work which they like.

Considerable importance was assigned to the work values of Ideas/Data, Altruism, Independence and Security. Respondents considerably valued a job that provided opportunities to work with and communicate facts and ideas; one that provided opportunities to work with other people in a helping, supportive role; and one that allowed independence in determining working conditions and was free from close supervision. To a slightly less degree, they also placed considerable value on having a job which is immune to unpredictable layoffs, steady, and dependable.

Finally, respondents assigned moderate importance to the work values of Money, Control, Object Orientation, Prestige, and Solitude. Instructors only moderately valued a job which provides a substantial income (earning more than enough money to satisfy life's basic needs) in which they have a leadership role or responsibility for other workers and in which the they handle or manipulate physical objects, such as utensils, materials, tools, or apparatus. Similarly, the instructor only moderately desired a job bringing recognition an an opportunity to meet and associate with important people. Finally, they placed moderate 
value on having a job in which they work in relative isolation from others.

\section{Descriptive Statistics for the Value Survey}

The procedures used in scoring the scales and the means and standard deviations of the value rankings on each scale are discussed in this section.

Scoring of the Rokeach Value Survey

The Rokeach Value Survey consists of two scales, one a list of $\underline{18}$ terminal values and the other a list of 18 instrumental values. Each list is ranked by the respondent in order of importance to that individual. This then presents two hierarchies of a value system for each respondent. Means and standard deviations are in reverse order of importance - the lower the means, the more desirable the value. Higher means denotes less desirable characteristics. As each respondent in the survey was scored, their highest value was given a 1 in the ranking, and the lowest value in each hierarchy was given a rank of 18 . As means and standard deviations were compiled on the rankings, a more desirable value had a smaller number, thus reversing the usual interpretation of means.

Rankings of the Rokeach Terminal Values

The means for each value of the RVS Terminal Value Survey ranged from 13.18 for the value of Social Recognition to 5.73 for the value of Health. The standard deviations of the 18 terminal values ranged 
from 3.85 for the value of Social Recognition to 6.70 for the value of Salvation. (See Table XXIII.)

In order of importance the following rankings were obtained from all respondents from most important to least important: Health; Self Respect; Family Security; Freedom; Inner Harmony; A Sense of Accomplishment; Wisdom; Mature Love; True Friendship; A World at Peace; An Exciting Life; Equality; A World of Beauty; A Comfortable Life; Salvation; Pleasure; National Security; and Social Recognition.

A Comfortable Life. The first value listed is A Comfortable Life which equates to a prosperous life. The mean score for this value was 11.47 , indicating respondents attached moderate importance to this value. The standard deviation was 4.60 .

An Exciting Life. The second value is An Exciting Life or a stimulating, active life. The mean score for this value was 10.68 with a standard deviation of 4.66 . Respondents also ranked this as of moderate importance, but of somewhat more importance than A Comfortable Life.

A Sense of Accomplishment. This value is also construed as the respondent feeling a sense of a lasting contribution to society. The mean was 7.74 with a standard deviation of 4.53 . This showed that, overall, respondents placed this value in the middle of the moderate to considerable importance category. 
TABLE XXIII

MEANS AND STANDARD DEVIATIONS FOR RVS TERMINAL VALUES

\begin{tabular}{lcc}
\hline \multicolumn{1}{c}{ Value } & Means & Standard Deviation \\
\hline A Comfortable Life & 11.47 & 4.60 \\
An Exciting Life & 10.68 & 4.66 \\
A Sense of Accomplishment & 7.74 & 4.53 \\
A World at Peace & 10.02 & 5.10 \\
A World of Beauty & 11.25 & 4.22 \\
Equality & 11.13 & 4.46 \\
Family Security & 6.54 & 4.59 \\
Freedom & 6.96 & 4.10 \\
Health & 5.73 & 3.90 \\
Inner Harmony & 7.24 & 4.48 \\
Mature Love & 8.57 & 4.52 \\
National Security & 13.13 & 4.53 \\
Pleasure & 12.54 & 4.17 \\
Salvation & 12.14 & 6.70 \\
Self Respect & 5.85 & 4.02 \\
Social Recognition & 13.18 & 3.85 \\
True Friendship & 8.97 & \\
Wisdom & 7.78 & \\
\hline & &
\end{tabular}

A World at Peace. The value of $A$ World at Peace means being free of war and conflict. This was the top of the moderate category and in the 
middle of listed terminal values. The mean was 10.02 with a standard deviation of 5.10 .

A World of Beauty. This value is further construed to be beauty of nature and the arts. The mean was 11.25 with a standard deviation of 4.22. Respondents placed this value in the moderate importance category and thirteenth value in importance overall.

Equality. The value of Equality is also listed as equating with brotherhood and an equal opportunity for a11. The mean was 11.13 with a standard deviation of 4.46 . This placed it in the middle of the moderate importance category and in 12 th place overal1.

Family Security. Family security means taking care of loved ones. This value had a mean of 6.54 and a standard deviation of 4.59 . Respondents placed it at the high end of the considerable importance category and in third place in the terminal value system.

Freedom. Freedom also means a matter of independence and free choice. Respondents gave it a mean of 6.96 and a standard deviation of 4.10 . This means that it was valued in the considerable importance category and in fourth place overall, only slightly behind the value of Family Security.

Health. Health is the next listed value. It also means a sense of mental and physical well-being for the individual. This value had a mean of 5.73 with a standard deviation of 3.90. Respondents placed great importance on this value as they felt it was the most important and placed it first of all the values. 
Ininer harmony. Inner harmony aiso means a sense of freedom from inner conflict. This value had a mean of 7.24 and a standard deviation of 4.48. This placed it at the top of the moderate to considerable importance category and in fifth place overall.

Mature Love. Mature Love equates to sexual and spiritual intimacy. This value had a mean of 8.57 with a standard deviation of 4.52 . This placed it at the lower part of the moderate to considerable importance category.

National Security. This value is also described as protection from attack. It had a mean of 13.13 and a standard deviation of 4.53 . This placed it in the of little importance category and in 17th position of 18 values.

Pleasure. Pleasure is further described as "as enjoyable, leisurely life". The value had a mean of 12.54 with a standard deviation of 4.17. This placed it in 16th place overall and at the bottom of the moderate importance category.

Salvation. Salvation is further defined as "a saved, eternal life". This value had a mean of 12.14 with a standard deviation of 6.70 . This placed it in the of moderate importance category for respondents.

Self Respect. The value is further described as that of self-esteem. It had a mean of 5.85 with a standard deviation of 4.02 . This value placed second overall and was deemed to be of great importance in the minds of instructors that answered the questionnaires. 
Social Recognition. Sociai Recognition also means having respect and admiration. Respondents deemed this to be of little importance and placed it last of all listed values. It had a mean of 13.18 with a standard deviation of 3.85 .

True Friendship. True Friendship also means close companionship. The value had a mean of 8.97 with a standard deviation of 4.18 . This value was at the bottom of the moderate to considerable importance category and in ninth place overall.

Wisdom. Wisdom also means "a mature understanding of life". The value had a mean of 7.78 with a standard deviation of 4.85 . The value was placed in the moderate to considerable importance category by respondents.

Summary of Rokeach Terminal Values

The scoring procedures and value definitions were reviewed. Means and standard deviations were reported for Rokeach terminal values. The value of Health had the lowest mean for the sample, indicating respondents assigned great importance to having good health. Of great importance also was Self Respect which had the next to the lowest mean. The value of Social Recognition was in 18th place, the lowest of all values. Values attracting considerable importance were Family Security and Freedom, which indicated considerable importance to taking care of loved ones and having independence and free choice. Moderate to considerable importance were given to the values of Harmony (freedom from inner conflict), A Sense of Accomplishment (lasting contribution), 
Wisdom (a mature understanding of life), Mature Love (sexual and spiritual intimacy), and True Friendship (close companionship). Moderate importance was given to An Exciting (stimulating, active) Life, Equality (brotherhood and equal opportunity), A World of Beauty (nature and the arts), A Comfortable (prosperous) Life, Salvation (a saved, eternal life), and Pleasure (an enjoyable and leisurely life). Respondents attached little importance to National Security or protection from attack, placing it in 17th position of all values.

Rankings of the Rokeach Instrumental Values

The means for each value of the Rokeach Value Survey Instrumental Values ranged from 15.05 for the value of Obedient to 4.87 for the value of Honest. The standard deviations of the 18 instrumental values ranged from 3.98 for Polite to 6.35 for the value of Loving. Table XXIV summarizes these statistics in more detail. Again, as in the terminal values, the rankings were from number 1 for a higher value to number 18 for a low value. This then denoted that as a higher mean is achieved a lower priority is placed on that value. 
TABLE XXIV

MEANS AND STANDARD DEVIATIONS FOR RVS INSTRUMENTAL VALUES

\begin{tabular}{lrc}
\hline \multicolumn{1}{c}{ Value } & Mean & Standard Deviation \\
\hline Ambitious & 10.36 & 5.27 \\
Broadminded & 9.06 & 4.74 \\
Capable & 7.71 & 4.18 \\
Clean & 13.17 & 4.66 \\
Courageous & 9.10 & 4.58 \\
Forgiving & 9.50 & 4.76 \\
Helpful & 8.62 & 4.60 \\
Honest & 4.87 & 4.10 \\
Imaginative & 10.19 & 4.83 \\
Independent & 7.97 & 4.81 \\
Intellectual & 8.58 & 4.93 \\
Logical & 10.06 & 6.14 \\
Loving & 7.65 & 6.35 \\
Loyal & 9.50 & 5.84 \\
Obedient & 15.05 & 4.22 \\
Polite & 12.59 & 3.98 \\
Responsible & 6.54 & 4.17 \\
Self Controlled & 11.22 & 4.68 \\
\hline & & \\
\hline
\end{tabular}

In order of importance the following rankings were obtained from a11 respondents from most important to least important: Honest; Responsible; Loving; Capable; Independent; Intellectual; Helpful; 
Broadminded; Courageous; Forgiving; Loyal; Logical; Imaginative; Ambitious; Self Controlled; Polite; Clean; and Obedient.

Ambitious. The value Ambitious is described further as "hard working and aspiring." The mean score for this value was 10.36 with a standard deviation of 5.27. Respondents placed the value in the moderate importance category.

Broadminded. This value is further appraised as being open-minded. It had a mean of 9.06 and a standard deviation of 4.74 . Respondents felt it was of moderate importance, as it was rated at the top of that category and was eighth out of the 18 instrumental values.

Capable. This value is also listed as feeling one's self as competent and effective. The mean was 7.71 with a standard deviation of 4.18 . Respondents felt it was of considerable importance and it was ranked fourth overall.

Clean. The value of Clean is also listed as neat and tidy. The mean for the value was 13.17 with a standard deviation of 4.66 . Overall it was deemed to have little importance and was ranked 17 th out of 18 values.

Courageous. This value is described as "standing up for your beliefs". The mean was 9.10 and a standard deviation of 4.58. Respondents placed it toward the top of the moderate importance category and in ninth place overall. 
Forgiving. Forgiving is further described as willing to pardon others. The mean was 9.50 with a standard deviation of 4.76 . It was tied with the value of Loyal and the two values were in tenth place out of the 18 instrumental values and in the moderate importance category.

Helpful. Being helpful also means working for the welfare of others. The mean for the value was 8.62 with a standard deviation of 4.60 . This value placed first of all values and in the great importance category. Imaginative. The Imaginative value is being "daring and creative". It carried a mean of 10.19 with a standard deviation of 4.83 . This placed it in the middle of the moderate importance category and in 13th place of all values.

Independent. The value is described as being self-reliant and self-sufficient. The mean was 7.97 and a standard deviation of 4.81 . It was of considerable importance to respondents.

Intellectual. The value of being intellectual is also described as being intelligent and reflective. The value had a mean of 8.58 with a standard deviation of 4.93. This placed it in the moderate to considerable importance category and in sixth place of the 18 instrumental values.

Logical. The value is further construed as being consistent and rationa1. The mean was 10.06 with a standard deviation of 6.14 . The value was categorized as being of moderate importance. It ranked in the middle of that category and in 12th position. 
Loving. The value of Loving is being affectionate and tender. It had a mean of 7.65 with a standard deviation of 6.35 . This placed it at the top of the considerable importance category and in third place in the instrumental value hierarchy.

Loyal. Loyal is further described as being faithful to one's friends and groups. It had a mean score of 9.50 with a standard deviation of 5.84. It was tied with the value of Forgiving and in tenth place of all instrumental values and in the moderate importance category.

Obedient. Obedient also means being dutiful and respectful. The value had a mean of 15.05 with a standard deviation of 4.22 . This value was rated lowest of all instrumental values and was in the of little importance category.

Polite. Polite is described as being courteous and well-mannered. It had a mean score of 12.59 with a standard deviation of 3.98. It was ranked in 16 th place of all values and was ranked in the bottom of the moderate importance category.

Responsible. This value is looked at as being dependable and reliable. The mean was 6.54 and a standard deviation of 4.17. Respondents rated it in second place of the instrumental values and in the great importance category.

Self Controlled. Self Controlled is described as being restrained and self-disciplined. The mean score for the value was 11.22 and the standard deviation was 4.68 . This placed it in the moderate importance category and in 15th place of the 18 instrumental values. 
Summary of the Rokeach Instrumentai Vaiues

The scoring procedures and value definitions were reviewed. Means and standard deviations were reported for instrumental values. The value of Honest (being sincere and truthful) had the lowest mean, which showed that respondents ranked it as the greatest importance. Of great importance also was the value of Responsible (dependable and reliable). The value of being obedient, which also means being dutiful and respectful, was ranked in last place of the instrumental values. Ranked next to last and also in the of little importance category was the value Clean, which equated to being neat and tidy. Of considerable importance to respondents were the values of Loving (being affectionate and tender), Capable (being competent and effective), and Independent which also means being self-reliant and self-sufficient. Of moderate to considerable importance were the values of being Intellectual (intelligent and reflective) and Helpful (working for the welfare of others). Values listed in the moderate importance category included being Broadminded (open-minded), Courageous (standing up for your beliefs), Forgiving (willing to pardon others), Loyal (faithful to one's friends and groups), Logical (consistent and rational), Imaginative (daring and creative), Ambitious (hard-working and aspiring), Self Controlled (restrained and self-disciplined), and Polite (courteous and well-mannered). 


\section{Values by Faculty Status}

Work values, terminal values, and instrumental values were examined by faculty status (full-time/part-time); the results are presented in this section.

Work Values

Scale means and standard deviation for the 11 constructs of the Ohio Work Values Inventory (OWVI) are presented for part-time and full-time faculty in Table XXV. For full-time faculty, the means ranged from 19.22 (Solitude) to 29.99 (Task Satisfaction). For part-time faculty, the means ranged from 18.28 (Solitude) to 32.49 (Task Satisfaction). For each group, the work values were ordered from most important to least important (See Table XXVI).

A multivariate analysis of variance was performed with faculty status (part-time/full-time) as the independent variable and the constructs of the OWVI as dependent variables. The $F$ value for Wilks' lambda test was $6.096(\mathrm{df}=11 \& 486)$; this was significant at the .05 level $(p=.000)$. 
TABLE XXV

MEANS AND STANDARD DEVIATIONS FOR THE SCALES OF THE OWVI FOR PART-TIME AND FULL-TIME FACULTY

\begin{tabular}{|c|c|c|c|c|c|c|}
\hline \multirow[t]{2}{*}{ Work Value } & \multicolumn{2}{|c|}{ Ful1-Time } & \multicolumn{2}{|c|}{ Part-Time } & \multicolumn{2}{|c|}{ Total } \\
\hline & Mean & S.D. & Mean & S.D. & Mean & S.D. \\
\hline Altruism & 26.68 & 5.09 & 28.29 & 5.34 & 27.44 & 5.33 \\
\hline Object Orientation & 20.00 & 6.78 & 18.55 & 6.81 & 19.16 & 6.83 \\
\hline Security & 24.28 & 6.13 & 24.99 & 6.81 & 24.98 & 6.54 \\
\hline Control & 21.52 & 6.52 & 20.53 & 6.49 & 20.95 & 6.47 \\
\hline Self Realization & 29.99 & 4.39 & 31.63 & 3.35 & 30.64 & 3.99 \\
\hline Independence & 26.33 & 4.38 & 27.83 & 4.81 & 27.19 & 4.69 \\
\hline Money & 23.47 & 6.67 & 23.49 & 7.31 & 23.48 & 7.04 \\
\hline Task Satisfaction & 29.75 & 4.95 & 32.49 & 3.34 & 31.33 & 4.31 \\
\hline Solitude & 19.22 & 5.51 & 18.28 & 5.76 & 18.67 & 5.67 \\
\hline Ideas/Data & 26.59 & 4.70 & 28.70 & 4.47 & 27.81 & 4.68 \\
\hline Prestige & 19.42 & 6.26 & 18.75 & 6.45 & 19.03 & 6.36 \\
\hline
\end{tabular}


TAOLE XXVI

RANK ORDER OF WORK VALUES FOR FULL-TIME

AND PART-TIME FACULTY

\begin{tabular}{cll}
\hline Rank & Full-time Instructors & Part-time Instructors \\
\hline 1. & Task Satisfaction & Task Satisfaction \\
2. & Self Realization & Self Realization \\
3. & Ideas/Data Orientation & Ideas/Data Orientation \\
4. & Independence & Altruism \\
5. & Altruism & Independence \\
6. & Security & Security \\
7. & Money & Money \\
8. & Control & Control \\
9. & Object Orientation & Prestige \\
10. & Prestige & Object Orientation \\
11. & Solitude & Solitude \\
\hline
\end{tabular}

With the rejection of the statistical hypothesis for the multivariate analysis, univariate analyses of variance were performed on the 11 dependent variables. (See Table XXVII.) For each variable, the statistical hypothesis that $\mu_{1}=\mu_{2}$ was tested, with six statistical hypotheses being rejected at the .05 level. Significant differences were found on Altruism, Object Orientation, Self Realization, Independence, Task Satisfaction, and Ideas/Data, with part-time instructors placing less emphasis on Object Orientation, while placing 
more emphasis on the other five work values than did full-time instructors.

TABLE XXVII

ANALYSIS OF VARIANCE FOR JOB STATUS USING WORK VALUES AS DEPENDENT VARIABLES

\begin{tabular}{lrrrrrr}
\hline \multicolumn{1}{c}{ Variable } & Hy SS & Error SS & Hy MS & Error MS & F* Sig.of F \\
\hline Altruism & 487.060 & 13607.510 & 487.060 & 27.435 & 17.754 & .000 \\
Object Orien. & 255.038 & 22906.110 & 255.038 & 46.182 & 5.523 & .019 \\
Security & 61.503 & 2166.001 & 61.503 & 42.673 & 1.441 & .231 \\
Control & 119.290 & 20716.246 & 119.290 & 41.767 & 2.856 & .092 \\
Self Real. & 664.742 & 7258.873 & 664.742 & 14.634 & 45.424 & .000 \\
Independence & 273.152 & 10647.725 & 273.152 & 21.467 & 12.724 & .000 \\
Money & 0.059 & 24606.278 & 0.059 & 49.609 & 0.001 & $.97 \%$ \\
Task Satis. & 911.418 & 8318.913 & 911.418 & 16.772 & 54.342 & .000 \\
Solitude & 108.075 & 15849.226 & 108.075 & 31.954 & 3.382 & .067 \\
Ideas/Data & 538.531 & 10341.575 & 538.531 & 20.850 & 25.829 & .000 \\
Prestige & 55.023 & 21005.397 & 55.023 & 40.555 & 1.357 & .245 \\
\hline
\end{tabular}

$\star \mathrm{df}=1,495$

Rokeach Terminal Values

Each faculty member ranked the 18 Rokeach Terminal Values. Scales means and standard deviation of the ranks are presented in Table XXVIII for full-time and part-time faculty members. For full-time faculty, the means ranged from 12.79 (Social Recognition) to 6.05 (Health). For 
TABLE XXVIII

MEANS AND STANDARD DEVIATIONS FOR THE TERMINAL VALUES OF THE RVS

FOR FULL-TIME AND PART-TIME FACULTY

\begin{tabular}{|c|c|c|c|c|c|c|}
\hline \multirow[t]{2}{*}{ Value } & \multicolumn{2}{|c|}{ Full-time } & \multicolumn{2}{|c|}{ Part-time } & \multicolumn{2}{|c|}{ Tota 1} \\
\hline & Mean & S.D. & Mean & S.D. & Mean & S.D. \\
\hline A Comfortable Life & 11.08 & 4.64 & 11.77 & 4.56 & 11.47 & 4.60 \\
\hline An Exciting Life & 10.51 & 4.75 & 10.78 & 4.59 & 10.68 & 4.66 \\
\hline A Sense of Accomp. & 8.08 & 4.68 & 7.49 & 4.41 & 7.74 & 4.53 \\
\hline A World at Peace & 10.09 & 4.91 & 9.98 & 5.24 & 10.02 & 5.10 \\
\hline A World of Beauty & 10.80 & 4.31 & 11.58 & 4.14 & 11.25 & 4.22 \\
\hline Equality & 10.91 & 4.64 & 11.30 & 4.33 & 11.13 & 4.46 \\
\hline Family Security & 6.82 & 4.90 & 6.34 & 4.35 & 6.54 & 4.59 \\
\hline Freedom & 7.35 & 4.12 & 6.67 & 4.07 & 6.96 & 4.10 \\
\hline Health & 6.05 & 4.32 & 5.50 & 3.54 & 5.73 & 3.90 \\
\hline Inner Harmony & 7.25 & 4.66 & 7.23 & 4.34 & 7.24 & 4.48 \\
\hline Mature Love & 8.38 & 4.90 & 8.71 & 4.23 & 8.57 & 4.52 \\
\hline National Security & 12.48 & 4.58 & 13.61 & 4.44 & 13.13 & 4.53 \\
\hline Pleasure & 12.06 & 4.42 & 12.90 & 3.94 & 12.54 & 4.17 \\
\hline Salvation & 12.04 & 6.47 & 12.22 & 6.87 & 12.14 & 6.70 \\
\hline Self Respect & 6.56 & 4.45 & 5.32 & 3.59 & 5.85 & 4.02 \\
\hline Social Recognition & 12.79 & 4.21 & 13.46 & 3.54 & 13.18 & 3.85 \\
\hline True Friendship & 8.89 & 4.41 & 9.03 & 4.02 & 8.97 & 4.18 \\
\hline Wisdom & 8.74 & 5.34 & 7.07 & 4.33 & 7.78 & 4.85 \\
\hline
\end{tabular}


part-time faculty, the means ranged from 13.61 (National Security) to 5.32 (Self Respect). For each group, the values were ordered from highest valued to least valued (See Table XXIX).

TABLE XXIX

RANK ORDER OF THE ROKEACH TERMINAL VALUES FOR FULL-TIME AND PART-TIME FACULTY

\begin{tabular}{rll}
\hline Rank & Full-time instructors & Part-time instructors \\
\hline 1 & Health & Self Respect \\
2 & Self Respect & Health \\
3 & Family Security & Family Security \\
4 & Inner harmony & Freedom \\
5 & Freedom & Wisdom \\
6 & A Sense of Accomplishment & Inner Harmony \\
7 & Mature Love & A Sense of Accomplishment \\
8 & Wisdom & Mature Love \\
9 & True Friendship & True Friendship \\
10 & A World at Peace & A World at Peace \\
11 & An Exciting Life & An Exciting Life \\
12 & A World of Beauty & Equality \\
13 & Equality & A World of Beauty \\
14 & A Comfortable Life & A Comfortable Life \\
15 & Salvation & Salvation \\
16 & Pleasure & Pleasure \\
17 & National Security & Social Recognition \\
18 & Social Recognition & National Security \\
\hline
\end{tabular}


A multivariate analysis of variance was performed, with faculty status as the independent variable and the terminal values of the RVS as dependent variables. The $F$ value for Wilks' test was 2.803 $(d f=18 \& 478)$; this was significant at the .05 level $(p=.000)$. With the rejection of the statistical hypothesis for the multivariate analysis, univariate analyses of variance were performed on the 18 terminal values. (See Table $X X X$. ) For each variable, the statistical hypothesis that $\mu_{1}=\mu_{2}$ was tested, with five statistical hypotheses being rejected at the .05 level. Significant differences were found on the values of A World of Beauty, National Security, Pleasure, Self Respect, and kisdom, with part-time instructors placing more value on Self Respect and Wisdom, and lesser value on A World of Beauty, National Security, and Pleasure than did full-time instructors.

\section{Rokeach Instrumental Values}

Each faculty member ranked the 18 Rokeach Instrumental Values. Scale means and standard deviations of the ranks are presented in Table XXXI for full-time and part-time faculty. For full-time faculty, the means ranged from 14.49 (Obedient) to 5.72 (Honest). For part-time faculty, the means ranged from 15.54 (Obedient) to 4.25 (Honest). For each group, the values were ordered from highest valued to least valued (See Table XXXII).

A multivariate analysis of variance was performed, with faculty status as the independent variable and the instrumental scales of the RVS as dependent variables. The F value for Wilks' test was 4.408 $(d f=18 \& 477)$; this was significant at the .05 level $(p=.000)$. 
TABLE XXX

ANALYSIS OF VARIANCE TABLE FOR JOB STATUS, USING ROKEACH

TERMINAL VALUES AS DEPENDENT VARIABLES

\begin{tabular}{lrrrrrrr}
\hline \multicolumn{1}{c}{ Variable } & Hy SS & Error SS & Hy MS & Error MS & F* & Sig. of F \\
\hline A Comfort. Life & 57.001 & 10454.935 & 57.001 & 21.121 & 2.699 & .101 \\
An Exciting Life & 8.522 & 10729.406 & 8.522 & 21.676 & 0.393 & .531 \\
Accomplishment & 40.926 & 10151.30 & 40.926 & 20.507 & 1.996 & .158 \\
A World at Peace & 1.463 & 12899.293 & 1.463 & 26.059 & 0.056 & .813 \\
A World of Beauty & 73.772 & 8767.290 & 73.772 & 17.712 & 4.165 & .042 \\
Equality & 18.657 & 9852.842 & 18.657 & 19.903 & 0.937 & .333 \\
Family Security & 28.472 & 10420.933 & 28.472 & 21.052 & 1.352 & .245 \\
Freedom & 52.996 & 8281.422 & 52.996 & 16.730 & 3.168 & .076 \\
Health & 38.265 & 7506.970 & 38.265 & 15.166 & 2.523 & .113 \\
Inner Harmony & 0.002 & 9918.054 & 0.002 & 20.036 & 0.001 & .992 \\
Mature Love & 13.740 & 10135.528 & 13.740 & 20.476 & 0.671 & .413 \\
National Security & 153.667 & 10034.832 & 153.667 & 20.272 & 7.580 & .006 \\
Pleasure & 85.061 & 8546.258 & 85.061 & 17.265 & 4.927 & .027 \\
Salvation & 4.194 & 22305.375 & 4.194 & 45.061 & 0.093 & .760 \\
Self Respect & 188.447 & 7843.932 & 188.447 & 15.846 & 11.892 & .001 \\
Social Recognition & 55.661 & 7298.041 & 55.661 & 14.744 & 3.775 & .053 \\
True Friendship & 2.685 & 8696.920 & 2.685 & 17.570 & 0.153 & .696 \\
Wisdom & 337.885 & 11340.875 & 337.885 & 22.911 & 14.748 & .000 \\
\hline *df = 1, 495 & & & & & & \\
\hline & & & & & & & \\
\hline
\end{tabular}


TABLE XXXI

MEANS AND STANDARD DEVIATIONS FOR THE INSTRUMENTAL VALUES OF THE RVS FOR FULL-TIME AND PART-TIME FACULTY

\begin{tabular}{|c|c|c|c|c|c|c|}
\hline \multirow[t]{2}{*}{ Value } & \multicolumn{2}{|c|}{ Full-time } & \multicolumn{2}{|c|}{ Part-time } & \multicolumn{2}{|c|}{ Total } \\
\hline & Mean & S.D. & Mean & S.D. & Mean & S.D. \\
\hline Ambitious & 10.74 & 5.28 & 10.08 & 5.26 & 10.36 & 5.27 \\
\hline Broadminded & 8.78 & 5.00 & 9.28 & 4.54 & 9.06 & 4.74 \\
\hline Capable & 7.66 & 4.23 & 7.41 & 4.14 & 7.71 & 4.18 \\
\hline Clean & 12.21 & 4.74 & 13.88 & 4.49 & 13.17 & 4.66 \\
\hline Courageous & 8.84 & 4.53 & 9.29 & 4.61 & 9.10 & 4.58 \\
\hline Forgiving & 9.19 & 4.73 & 9.72 & 4.78 & 9.50 & 4.76 \\
\hline Helpful & 9.17 & 4.86 & 8.22 & 4.37 & 8.62 & 4.60 \\
\hline Honest & 5.72 & 4.63 & 4.25 & 3.53 & 4.87 & 4.10 \\
\hline Imaginative & 9.72 & 5.01 & 10.54 & 4.68 & 10.19 & 4.83 \\
\hline Independent & 8.33 & 4.99 & 7.70 & 4.57 & 7.97 & 4.81 \\
\hline Intelligent & 8.67 & 4.85 & 8.52 & 5.00 & 8.58 & 4.93 \\
\hline Logical & 10.25 & 5.10 & 9.62 & 4.45 & 10.06 & 6.14 \\
\hline Loving & 7.69 & 5.28 & 7.27 & 4.85 & 7.65 & 6.35 \\
\hline Loyal & 8.78 & 4.74 & 9.74 & 4.38 & 9.50 & 5.84 \\
\hline Obedient & 14.39 & 4.74 & 15.54 & 3.72 & 15.05 & 4.22 \\
\hline Polite & 12.02 & 4.31 & 13.01 & 3.67 & 12.59 & 3.98 \\
\hline Responsible & 7.41 & 4.48 & 5.74 & 3.77 & 6.45 & 4.17 \\
\hline Self Controlled & 11.49 & 4.62 & 11.02 & 4.72 & 11.22 & 4.68 \\
\hline
\end{tabular}


TABLE XXXII

RANK ORDER OF THE ROKEACH INSTRUHENTAL VÁLUUES FOR

PART-TIME AND FULL-TIME FACULTY

\begin{tabular}{|c|c|c|}
\hline Rank & Full-time instructors & Part-time instructors \\
\hline 1 & Honest & Honest \\
\hline 2 & Responsible & Responsible \\
\hline 3 & Capable & Loving \\
\hline 4 & Loving & Capable \\
\hline 5 & Independent & Independent \\
\hline 6 & Intellectual & Helpful \\
\hline 7 & Broadminded & Intellectual \\
\hline 8 & Loyal (tie w/broadminded) & Broadminded \\
\hline 9 & Courageous & Courageous \\
\hline 10 & Helpful & Logical \\
\hline 11 & Forgiving & Forgiving \\
\hline 12 & Imaginative & Loyal \\
\hline 13 & Logical & Ambitious \\
\hline 14 & Ambitious & Imaginative \\
\hline 15 & Self Controlled & Self Controlled \\
\hline 16 & Polite & Polite \\
\hline 17 & Clean & Clean \\
\hline 18 & Obedient & Obedient \\
\hline
\end{tabular}

With the rejection of the statistical hypothesis for the multivariate analysis, univariate analysis of variance were performed on 
the instrumental values (See Table XXXIII). For each variable, the statistical hypothesis that $\mu_{1}=\mu_{2}$ was tested at the .05 level. Significant differences were found on the values of Clean, Helpful, Honest, Obedient, Polite, and Responsible, with full-time instructors placing less value on Helpful, Honest, and Responsible and more value on Clean, Obedient, and Polite than did the part-time faculty members.

\section{Values by Job Assignment}

Work values, terminal values, and instrumental values were examined by job assignment of instructors (Natural Science, Social Science, Mathematics, English, Auto/Industrial Mechanics, Business Education, Secretarial Science, and Health). The results are presented in this section.

Work Values

Scale means and standard deviations for the 11 constructs of the OWVI are presented for the eight instructional areas in Tables XXXIV and $X X X X$. For the Natural Science instructors, the means ranged from 15.74 (Prestige) to 31.45 (Task Satisfaction). For Social Science instructors, the means ranged from 18.69 (Object Orientation) to 30.61 (Task Satisfaction). For the Mathematics instructors, the means ranged from 18.72 (Object Orientation) to 30.51 (Task Satisfaction). The range of means for the English instructors was 16.87 (Object Orientation) to 31.77 (Task Satisfaction). 
TABLE XXXIII

ANALYSIS OF VARIANCE TABLE FOR JOB STATUS, USING ROKEACH

INSTRUMENTAL VALUES AS DEPENDENT VARIABLES

\begin{tabular}{lrrrrrrr}
\hline \multicolumn{1}{c}{ Variable } & Hy SS & Error SS & Hy MS & Error MS & F* & Sig.of F \\
\hline Ambitious & 50.184 & 13720.766 & 50.184 & 27.775 & 1.807 & .180 \\
Broadminded & 31.009 & 11116.379 & 31.009 & 22.503 & 1.378 & .241 \\
Capable & 7.127 & 8646.583 & 7.127 & 17.503 & 0.407 & .524 \\
Clean & 339.006 & 10426.769 & 339.006 & 21.107 & 16.061 & .000 \\
Courageous & 22.923 & 10343.174 & 22.923 & 20.938 & 1.095 & .296 \\
Forgiving & 33.415 & 11176.577 & 33.415 & 22.625 & 1.477 & .225 \\
Helpful & 109.319 & 10332.932 & 109.319 & 20.917 & 5.226 & .023 \\
Honest & 257.018 & 8053.724 & 257.018 & 16.303 & 15.765 & .000 \\
Imaginative & 84.580 & 11505.451 & 84.580 & 23.290 & 3.632 & .057 \\
Independent & 43.238 & 11430.633 & 43.238 & 23.139 & 1.869 & .172 \\
Intellectual & 2.133 & 12029.222 & 2.133 & 24.351 & 0.088 & .767 \\
Logical & 129.105 & 18577.425 & 129.105 & 37.606 & 3.433 & .064 \\
Loving & 98.261 & 19888.141 & 98.261 & 40.259 & 2.441 & .119 \\
Loyal & 41.815 & 16852.153 & 41.815 & 34.114 & 1.226 & .269 \\
Obedient & 163.428 & 8646.758 & 163.428 & 17.504 & 9.337 & .002 \\
Polite & 119.204 & 7734.893 & 119.204 & 15.658 & 7.613 & .006 \\
Responsible & 336.086 & 8280.938 & 336.086 & 16.763 & 20.049 & .000 \\
Self Controlled & 24.637 & 10814.234 & 24.637 & 21.891 & 1.125 & .289 \\
\hline & & & & & & \\
\hline
\end{tabular}

$\star d f=1,494$ 
TABLE XXXIV

SCALE MEANS ON THE OHIO WORK VALUES INVENTORY FOR THE LEVELS OF JOB ASSIGNMENT

\begin{tabular}{lllllllll}
\hline $\begin{array}{c}\text { OwvI } \\
\text { Scales }\end{array}$ & $\begin{array}{c}\text { Nat. Sci } \\
\text { (Group 1) }\end{array}$ & $\begin{array}{c}\text { Soc. Sci } \\
\text { (Group 2) }\end{array}$ & $\begin{array}{c}\text { Math } \\
\text { (Group 3) }\end{array}$ & $\begin{array}{c}\text { English } \\
\text { (Group 4) }\end{array}$ & $\begin{array}{c}\text { Au/IndMe } \\
\text { (Group 5) }\end{array}$ & $\begin{array}{c}\text { Bus. Ed. } \\
\text { (Group 6) }\end{array}$ & $\begin{array}{c}\text { Sec. Sci } \\
\text { (Group 7) }\end{array}$ & $\begin{array}{c}\text { Health } \\
(\text { Group 8) }\end{array}$ \\
\hline Altruism & 25.776 & 25.629 & 26.180 & 29.267 & 27.420 & 27.277 & 27.086 & 30.092 \\
Object Orient. & 18.612 & 18.694 & 18.721 & 16.867 & 26.420 & 17.575 & 18.452 & 19.132 \\
Security & 23.959 & 25.048 & 23.820 & 25.017 & 25.380 & 24.489 & 23.710 & 26.145 \\
Control & 18.592 & 19.100 & 19.082 & 19.533 & 23.160 & 22.340 & 22.882 & 21.895 \\
Self Realiz. & 30.510 & 30.177 & 29.574 & 31.050 & 30.300 & 30.404 & 30.495 & 32.158 \\
Independence & 26.694 & 27.677 & 26.656 & 27.617 & 26.020 & 26.489 & 27.914 & 27.526 \\
Money & 20.347 & 21.726 & 22.918 & 22.017 & 25.220 & 24.064 & 24.989 & 25.197 \\
Task Satis. & 31.449 & 30.613 & 30.508 & 31.767 & 30.720 & 31.128 & 31.656 & 32.290 \\
Solitude & 19.408 & 20.661 & 19.000 & 18.567 & 19.380 & 16.660 & 18.430 & 17.487 \\
Ideas/Data & 28.592 & 28.887 & 27.312 & 29.250 & 26.850 & 25.447 & 27.484 & 28.329 \\
Prestige & 15.735 & 19.016 & 19.098 & 19.800 & 19.200 & 18.106 & 19.946 & 19.868 \\
\hline
\end{tabular}


TABLE XXXV

SCALE STANDARD DEVIATIONS ON THE OHIO WORK VALUES INVENTORY FOR THE LEVELS OF JOB ASSIGNMENT

\begin{tabular}{|c|c|c|c|c|c|c|c|c|}
\hline $\begin{array}{c}\text { OWVI } \\
\text { Scales }\end{array}$ & $\begin{array}{l}\text { Nat. Sci. } \\
\text { Group } 1\end{array}$ & $\begin{array}{l}\text { Soc. Sci. } \\
\text { Group } 2\end{array}$ & $\begin{array}{l}\text { Math } \\
\text { Group } 3\end{array}$ & $\begin{array}{l}\text { English } \\
\text { Group } 4\end{array}$ & $\begin{array}{l}\text { Au/IndMec } \\
\text { Group } 5\end{array}$ & $\begin{array}{l}\text { Bus. Ed. } \\
\text { Group } 6\end{array}$ & $\begin{array}{l}\text { Sec. Sci. } \\
\text { Group } 7\end{array}$ & $\begin{array}{l}\text { Health } \\
\text { Group } 8\end{array}$ \\
\hline Altruism & 5.878 & 6.239 & 4.165 & 4.704 & 5.099 & 6.053 & 5.073 & 4.007 \\
\hline Object Orien. & 4.830 & 7.517 & 5.672 & 6.371 & 5.897 & 5.763 & 6.902 & 6.830 \\
\hline Security & 6.837 & 6.839 & 6.214 & 5.537 & 6.602 & 5.910 & 7.268 & 6.372 \\
\hline Control & 6.188 & 6.010 & 6.783 & 6.395 & 6.018 & 6.472 & 6.162 & 6.172 \\
\hline Self Real. & 3.884 & 4.489 & 4.039 & 4.280 & 3.980 & 3.866 & 3.930 & 3.213 \\
\hline Independence & 5.249 & 5.134 & 4.175 & 5.123 & 4.636 & 3.923 & 4.781 & 4.209 \\
\hline Money & 6.866 & 8.000 & 6.756 & 6.939 & 5.836 & 4.984 & 7.465 & 6.829 \\
\hline Task Satis. & 3.348 & 5.006 & 4.599 & 3.942 & 4.576 & 4.990 & 4.282 & 3.528 \\
\hline Solitude & 5.597 & 6.035 & 4.539 & 5.640 & 5.484 & 5.176 & 6.172 & 5.544 \\
\hline Ideas/Data & 4.153 & 5.035 & 4.614 & 4.524 & 4.136 & 5.145 & 4.539 & 4.413 \\
\hline Prestige & 5.526 & 7.030 & 5.876 & 6.022 & 5.581 & 5.891 & 6.966 & 6.481 \\
\hline
\end{tabular}


For the Automotive/Industrial Mechanics group the means ranged from 19.20 (Prestige) to 30.72 (Task Satisfaction). For Business Education, the means ranged from 16.66 (Solitude) to 31.13 (Task Satisfaction). For the Secretarial Science group, the means ranged from 18.43 (Solitude) to 31.66 (Task Satisfaction). And, for the Health group, the means ranged from 17.49 (Solitude) to 32.29 (Task Satisfaction).

A multivariate analysis of variance was performed, using job assignment as the independent variable and work values as dependent variables. With 77 and 3348 degrees of freedom, the Wilks' lambda value $(F=3.7953)$ was significant at the .05 level of confidence $(p<.001)$. With the rejection of the statistical hypothesis for the multivariate analysis, univariate analyses of variance were performed on the dependent variables, using a .05 level of confidence for each test. The statistical hypotheses that $\mu_{1}=\mu_{2}=\ldots=\mu_{8}$ was rejected for eight work values (See Table XXXVI).

On each of these eight variables, a modified LSD was performed for each pair-wise mean comparison, using a .05 level of confidence. Group means and standard deviations were presented in Tables XXXIV and XXXV. A summary of significant differences between group means is found in Table XXXVII. As may be seen, English and Health instructors placed greater value on Altruism than did Natural Science, Social Science, and Mathematics instructors. Health instructors also placed greater value on Altruism than did Secretarial Science instructors. Auto/Industrial Mechanics instructors placed greater value on Object Orientation than did any other group. Auto/Industrial and Secretarial Science 
TABLE XXXVI

ANALYSIS OF VARIANCE TABLE FOR THE JOB ASSIGNMENT VARIABLE USING WORK VALUES AS DEPENDENT VARIABLES

\begin{tabular}{|c|c|c|c|c|c|c|}
\hline Variable & Hy SS & Error SS & Hy MS & Error MS & $F^{*}$ & Sig. of $F$ \\
\hline Altruism & 1183.571 & 12910.999 & 169.082 & 26.349 & 6.417 & .000 \\
\hline Object Orient. & 3155.757 & 20005.392 & 450.822 & 40.827 & 11.042 & .000 \\
\hline Security & 362.637 & 20864.867 & 51.805 & 42.581 & 1.217 & .292 \\
\hline Control & 1568.627 & 19266.910 & 224.090 & 39.320 & 5.699 & .000 \\
\hline Self Realization & 278.982 & 7644.233 & 39.855 & 15.600 & 2.255 & .014 \\
\hline Independence & 203.983 & 10716.894 & 29.140 & 21.871 & 1.332 & .233 \\
\hline Money & 1422.906 & 23183.431 & 203.272 & 47.313 & 4.296 & .000 \\
\hline Task Satisfact. & 185.585 & 9044.746 & 26.512 & 18.459 & 1.436 & .188 \\
\hline Sol itude & 606.728 & 15350.573 & 86.675 & 31.328 & 2.767 & .008 \\
\hline Ideas/Data & 609.929 & 10270.178 & 87.133 & 20.960 & 4.157 & .000 \\
\hline Prestige & 740.991 & 19429.428 & 105.856 & 39.652 & 2.670 & .010 \\
\hline \multicolumn{7}{|c|}{$\begin{array}{l}\text { *df }=7,490 \\
\text { instructors placed greater value on Control than did Natural Science, } \\
\text { Social Science, and Mathematics instructors. Secretarial Science } \\
\text { instructors also placed greater value on Control than did Health } \\
\text { instructors. Health instructors placed greater value on Self } \\
\text { Realization than Mathematics instructors. Natural Science instructors } \\
\text { placed less value on Money than did Auto/Industrial Mechanics, } \\
\text { Secretarial Science and Health instructors. Social Science instructors }\end{array}$} \\
\hline
\end{tabular}


TABLE XXXYVII

SIGNIFICANT PAIR-WISE COMPARISONS BETWEEN LEVELS OF JOB ASSIGNMENT ON THE OHIO WORK VALUES INVENTORY

\begin{tabular}{ll}
\hline \multicolumn{1}{c}{ OWvI Scales } & Pair-wise Group Comparisons* \\
\hline Altruism & $1-8,2-4,2-8,3-8,7-8,1-4,3-4$ \\
Object Orientation & $1-5,2-5,3-5,4-5,6-5,7-5,8-5$ \\
Control & $1-5,2-5,3-5,1-7,2-7,3-7,4-7$ \\
Self Realization & $3-8$ \\
Money & $1-5,1-7,1-8$ \\
Solitude & $2-6,2-8$ \\
Ideas/Data & $1-6,2-6,4-6,6-8$ \\
Prestige & $1-4,1-7,1-8$ \\
\hline
\end{tabular}

*Natural Science (1); Social Science (2); Mathemathics (3); English (4); Auto/Industrial Mechanics (5); Business Education (6); Secretarial Science (7); and Health (8)

placed greater yalue on Solitude than did Business Education and Health instructors. Business Education instructors placed less value on Ideas/Data than did Natural Science, Social Science, English and Health instructors. Natural Science instructors placed less value on Prestige than did English, Secretarial Science and Health instructors.

The work values within each job assignment group were ordered by means. The rank orders for the various groups are shown in the Table XXXVIII. For each group, Task Satisfaction ranked first and Self Realization ranked second. 
TABLE XXXVIII

RANK ORDER OF WORK VALUES FOR INSTRUCTORS CLASSIFIED BY JOB ASSIGNMENT

\begin{tabular}{llllllll}
\hline $\begin{array}{l}\text { Nat. Sci. } \\
\text { (Group 1) }\end{array}$ & $\begin{array}{c}\text { Soc. Sci. } \\
\text { (Group 2) }\end{array}$ & $\begin{array}{c}\text { Math } \\
\text { (Group 3) }\end{array}$ & $\begin{array}{c}\text { English } \\
\text { (Group 4) }\end{array}$ & $\begin{array}{l}\text { Au/IndMe } \\
\text { (Group 5) }\end{array}$ & $\begin{array}{l}\text { Bus. Ed. } \\
\text { (Group 6) }\end{array}$ & $\begin{array}{l}\text { Sec. Sci. } \\
\text { (Group 7) }\end{array}$ & $\begin{array}{c}\text { Health } \\
\text { (Group 8) }\end{array}$ \\
\hline Task Sat. & Task Sat. & Task Sat. & Task Sat. & Task Sat. & Task Sat. & Task Sat. & Task Sat. \\
Self Real. & Self Real. & Self Real. & Self Real. & Self Real. & Self Real. & Self Real. & Self Real. \\
Ideas/Data & Ideas/Data & Ideas/Data & Altruism & Altruism & Altruism & Altruism & Altruism \\
Indepen. & Indepen. & Indepen. & Ideas/Data & Ideas/Data & Indepen. & Ideas/Data & Ideas/Data \\
Altruism & Altruism & Altruism & Indepen. & Obj. Orien. Ideas/Data & Altruism & Indepen. \\
Security & Security & Security & Security & Indepen. & Security & Money & Security \\
Money & Money & Money & Money & Security & Money & Security & Money \\
Solitude & Solitude & Prestige & Prestige & Money & Control & Control & Control \\
Obj. Orien. Control & Control & Control & Control & Prestige & Prestige & Prestige \\
Control & Prestige & Solitude & Solitude & Solitude & Obj. Orien. Obj. Orien. Obj. Orien. \\
Prestige & Obj. Orien. & Obj. Orien. & Obj. Orien. & Prestige & Solitude & Solitude & Solitude \\
\hline
\end{tabular}


Rokeach Terminal Values

Each faculty member ranked the 18 Rokeach Terminal Scales. Scale means and standard deviations of the ranks for the various categories of job assignment are presented in tables $X X X I X$ and $X L$. The means for the Natural Science group ranged from 15.04 (National Security) to 4.98 (Health). The means for the Social Science group ranged from 13.77 (National Security) to 5.66 (Freedom). The means for the Mathematics group ranged from 13.69 (National Security) to 5.80 (Self Respect). The means for the English group ranged from 14.45 (National Security) to 6.08 (Self Respect). The means for the Auto/Industrial Mechanics group ranged from 12.84 (Pleasure) to 5.02 (Health). The means for the Business Education group ranged from 13.19 (Social Recognition) to 5.70 (Health). The means for the Secretarial Science group ranged from 13.40 (Social Recognition) to 5.32 (Health). The means for the Health Occupation group ranged from 13.49 (Social Recognition) to 4.38 (Self Respect).

A multivariate analysis of variance was performed, using Job Assignment as the indeperident variable and the Rokeach terminal values as dependent variables. With 126 and 3292 degrees of freedom, the Wilks' lambda $(F=1.8819)$ was significant at the .05 level of confidence $(p<.001)$. With the rejection of the statistical hypothesis for the multivariate analysis, univariate analyses were performed on the dependent variables, using a .05 level of confidence for each test. The statistical hypothesis that $\mu_{1}=\mu_{2}=\ldots .=\mu_{8}$ was rejected for 10 terminal values (See Table XLI). 
TABLE XXXIX

SCALE MEANS ON THE ROKEACH TERMINAL VALUES SURVEY FOR VALUES OF JOB ASSIGNMENT

\begin{tabular}{|c|c|c|c|c|c|c|c|c|}
\hline $\begin{array}{c}\text { RVS } \\
\text { Scales }\end{array}$ & $\begin{array}{l}\text { Nat. Sci. } \\
\text { Group } 1\end{array}$ & $\begin{array}{l}\text { Soc. Sci. } \\
\text { Group } 2\end{array}$ & $\begin{array}{l}\text { Math } \\
\text { Group } 3\end{array}$ & $\begin{array}{l}\text { English } \\
\text { Group } 4\end{array}$ & $\begin{array}{c}\text { Au/IndMec } \\
\text { Group } 5\end{array}$ & $\begin{array}{l}\text { Busi. Ed. } \\
\text { Group } 6\end{array}$ & $\begin{array}{l}\text { Sec. Sci. } \\
\text { Group } 7\end{array}$ & $\begin{array}{l}\text { Health } \\
\text { Group } 8\end{array}$ \\
\hline A Comfort. Life & 12.082 & 12.113 & 10.721 & 12.900 & 10.280 & 11.170 & 10.663 & 12.000 \\
\hline An Exciting Life & 9.755 & 9.597 & 10.918 & 9.750 & 11.220 & 12.192 & 10.761 & 11.461 \\
\hline A Sense of Accomp. & 6.898 & 6.952 & 8.197 & 7.467 & 7.460 & 7.468 & 8.565 & 8.171 \\
\hline A World at Peace & 11.020 & 9.952 & 9.820 & 8.500 & 10.520 & 9.745 & 10.500 & 10.066 \\
\hline A World of Beauty & 11.041 & 9.871 & 11.312 & 9.050 & 12.420 & 11.128 & 12.250 & 12.290 \\
\hline Equality & 11.327 & 10.290 & 10.853 & 9.733 & 12.500 & 11.894 & 11.696 & 10.961 \\
\hline Family Security & 7.061 & 8.226 & 6.049 & 7.883 & 5.420 & 6.149 & 5.576 & 6.316 \\
\hline Freedom & 6.510 & 5.661 & 7.016 & 6.667 & 8.440 & 7.617 & 6.685 & 7.487 \\
\hline Health & 4.980 & 7.323 & 6.066 & 7.033 & 5.020 & 5.702 & 5.315 & 4.566 \\
\hline Inner Harmony & 6.898 & 8.419 & 7.426 & 6.900 & 7.020 & 6.532 & 7.261 & 7.263 \\
\hline Mature Love & 8.265 & 8.758 & 8.049 & 8.750 & 8.840 & 9.085 & 8.750 & 8.224 \\
\hline National Security & 15.041 & 13.774 & 13.689 & 14.450 & 11.020 & 11.085 & 12.500 & 13.303 \\
\hline Pleasure & 12.429 & 12.419 & 12.590 & 12.715 & 12.840 & 12.340 & 12.109 & 13.000 \\
\hline Salvation & 13.245 & 13.387 & 12.115 & 14.233 & 11.120 & 11.021 & 10.924 & 11.645 \\
\hline Self Respect & 5.184 & 5.774 & 5.803 & 6.083 & 6.500 & 6.681 & 6.554 & 4.382 \\
\hline Social Recog. & 14.204 & 12.403 & 13.000 & 12.983 & 12.720 & 13.192 & 13.402 & 13.487 \\
\hline True Friendship & 8.429 & 9.113 & 8.689 & 8.783 & 9.360 & 8.851 & 9.957 & 8.211 \\
\hline Wisdom & 6.776 & 6.968 & 8.295 & 7.117 & 8.480 & 9.234 & 7.554 & 8.079 \\
\hline
\end{tabular}


TABLE XL

SCALE STANDARD DEVIATIONS ON THE ROKEACH TERMINAL VALUES SURVEY FOR LEVELS OF JOB ASSIGNMENT

\begin{tabular}{lcccccccc}
\hline \multicolumn{1}{c}{$\begin{array}{c}\text { RvS } \\
\text { Scales }\end{array}$} & $\begin{array}{c}\text { Nat. Sci. } \\
\text { Group } 1\end{array}$ & $\begin{array}{c}\text { Soc. Sci. } \\
\text { Group 2 }\end{array}$ & $\begin{array}{c}\text { Math } \\
\text { Group } 3\end{array}$ & $\begin{array}{c}\text { English } \\
\text { Group 4 }\end{array}$ & $\begin{array}{c}\text { Au/IndMec } \\
\text { Group 5 }\end{array}$ & $\begin{array}{c}\text { Bus. Ed. } \\
\text { Group 6 }\end{array}$ & $\begin{array}{c}\text { Sec. Sci. } \\
\text { Group } 7\end{array}$ & $\begin{array}{c}\text { Health } \\
\text { Group 8 }\end{array}$ \\
\hline A Comfort. Life & 3.220 & 4.649 & 4.723 & 4.580 & 5.399 & 4.918 & 4.461 & 4.339 \\
An Exciting Life & 4.304 & 4.411 & 4.755 & 4.417 & 5.433 & 4.282 & 4.846 & 4.303 \\
A Sense of Accomp. & 4.570 & 3.461 & 5.138 & 4.436 & 4.409 & 4.653 & 4.752 & 4.527 \\
A World at Peace & 4.571 & 5.488 & 4.965 & 4.717 & 5.219 & 5.499 & 5.240 & 4.922 \\
A World of Beauty & 4.495 & 4.643 & 3.956 & 4.135 & 3.737 & 4.456 & 3.977 & 3.498 \\
Equality & 4.049 & 5.052 & 4.191 & 4.414 & 4.062 & 4.145 & 4.831 & 4.133 \\
Family Security & 4.922 & 4.890 & 4.559 & 4.694 & 4.190 & 5.000 & 3.995 & 4.237 \\
Freedom & 3.606 & 3.979 & 3.905 & 3.852 & 3.929 & 4.712 & 4.134 & 4.222 \\
Health & 3.218 & 3.639 & 4.320 & 3.764 & 4.103 & 3.923 & 3.536 & 3.961 \\
Inner Harmony & 4.478 & 4.758 & 4.573 & 4.761 & 4.073 & 4.026 & 4.164 & 4.787 \\
Mature Love & 4.712 & 4.326 & 4.787 & 4.459 & 4.609 & 4.708 & 4.464 & 4.423 \\
National Security & 3.041 & 4.550 & 3.998 & 4.485 & 4.474 & 5.064 & 4.611 & 4.403 \\
Pleasure & 4.253 & 4.260 & 4.080 & 3.928 & 3.722 & 4.395 & 4.616 & 3.997 \\
Salvation & 6.966 & 6.421 & 6.674 & 5.302 & 6.552 & 6.703 & 7.011 & 7.125 \\
Self Respect & 3.296 & 3.404 & 4.258 & 4.473 & 4.523 & 4.644 & 4.346 & 2.668 \\
Social Recog. & 2.858 & 4.163 & 3.795 & 4.575 & 4.747 & 3.379 & 3.400 & 3.668 \\
True Friendship & 3.851 & 4.451 & 4.350 & 4.251 & 3.821 & 4.709 & 4.161 & 3.834 \\
Wisdom & 4.278 & 5.423 & 4.910 & 5.218 & 4.917 & 4.415 & 4.944 & 4.289 \\
\hline & & & & & & & \\
\hline
\end{tabular}


On each of these ten variables a Modified LSD was performed for each pair-wise mean comparison, using a .05 level of confidence. Group means and standard deviations were presented in Tables XXXIX and XL. A summary of significant differences between group means is found in Table XLII. As may be seen, Social Science and English instructors placed more value on A World of Beauty than did Auto/Industrial Mechanics, Secretarial Science, and Health instructors. Auto/Industrial Mechanics instructors placed less value on Equality than did English instructors. Social Science instructors placed less value on Family Security than did Auto/Industrial Mechanics and Secretarial Science instructors. Auto/Industrial Mechanics instructors placed less value on Freedom than did Social Science instructors. Social Science instructors placed less value on Health than did Natural Science, Auto/Industrial Mechanics, Secretarial Science, and Health instructors, while English instructors placed less value on Health than did Health instructors. Auto/Industrial Mechanics instructors placed more value on National Security than did Natural Science, Social Science, Mathematics, and English instructors. Business Education instructors placed more value on National Security than did Natural Science, Social Science, and English instructors; Secretarial Science placed greater value on National Security than did Natural Science Instructors. Health instructors placed more value on Self Respect than did Secretarial Science instructors. Significant pair-wise means differences were not found on A Comfortable Life, An Exciting Life, and Salvation. 
TABLE XLI

ANALYSIS OF VARIANCE TABLE FOR THE JOB ASSIGNMENT VARIABLE USING TERMINAL VALUES AS DEPENDENT VARIABLES

\begin{tabular}{lrrrrrr}
\hline \multicolumn{1}{c}{ Variable } & Hy SS & Error SS & Hy MS & Error MS & $F^{*}$ & Sig. of F \\
\hline A Comfortable Life & 357.118 & 10154.818 & 51.017 & 20.767 & 2.457 & .017 \\
An Exciting Life & 338.630 & 10399.298 & 48.376 & 21.266 & 2.275 & .028 \\
A Sense of Accomplish. & 174.632 & 10017.424 & 24.947 & 20.486 & 1.218 & .291 \\
A World at Peace & 227.818 & 12672.938 & 32.546 & 25.916 & 1.256 & .271 \\
A World of Beauty & 653.949 & 8187.114 & 93.421 & 16.743 & 5.580 & .000 \\
Equality & 320.216 & 9550.283 & 45.745 & 19.530 & 2.342 & .023 \\
Family Security & 471.688 & 9977.717 & 67.384 & 20.404 & 3.302 & .002 \\
Freedom & 277.698 & 8056.721 & 39.671 & 16.476 & 2.408 & .020 \\
Health & 437.697 & 7107.539 & 62.526 & 14.535 & 4.302 & .000 \\
Inner Harmony & 126.994 & 9791.063 & 18.142 & 20.023 & 0.906 & .501 \\
Mature Love & 53.416 & 10095.851 & 7.631 & 20.646 & 0.370 & .920 \\
National Security & 786.131 & 9402.368 & 112.304 & 19.228 & 5.841 & .000 \\
Pleasure & 43.099 & 8588.220 & 6.157 & 17.563 & 0.351 & .930 \\
Salvation & 684.734 & 2164.835 & 97.819 & 44.223 & 2.212 & .032 \\
Self Respect & 288.595 & 7743.784 & 41.228 & 15.836 & 2.603 & .012 \\
Social Recognition & 115.377 & 7238.325 & 16.482 & 14.802 & 1.114 & .353 \\
True Friendship & 164.196 & 8535.410 & 23.457 & 17.455 & 1.344 & .227 \\
Wisdom & 268.263 & 11410.498 & 38.323 & 23.334 & 1.642 & .121 \\
\hline
\end{tabular}


TABLE XLII

SIGNIFICANT PAIR-WISE MEAN COMPARISONS BETWEEN LEVELS OF JOB ASSIGNMENT ON THE ROKEACH TERMINAL VALUES

\begin{tabular}{ll}
\hline RVS Terminal Scale & Pair-Wise Group Comparisons* \\
\hline A World of Beauty & $2-5,2-7,2-8,4-5,4-7,4-8$ \\
Equality & $4-5$ \\
Family Security & $2-5,2-7$ \\
Freedom & $2-5$ \\
Health & $1-2,2-5,2-7,2-8,4-8$ \\
National Security & $5-1,5-2,5-3,5-4,6-1,6-2$, \\
& $6-4,7-1$ \\
Self Respect & $7-8$ \\
\hline
\end{tabular}

* Natural Science (1); Social Science (2); Mathematics (3); English (4); Auto/Industrial Mechanics (5); Business Education (6); Secretarial Science (7); and Health (8)

Rokeach Instrumental Values

Scale means and standard deviations of the ranks of the Rokeach Instrumental Values are presented for categories of job assignment in Tables XLIII and XLIV. The means for the National Science group ranged from 15.20 (Obedient) to 4.25 (Honest). The means for the Social Science group ranged from 15.50 (Obedient) to 5.94 (Honest). The means for the Mathematics group ranged from 15.10 (Obedient) to 5.47 (Honest). The means for the English group ranged from 15.88 (Obedient) to 5.33 (Honest). The means for the Auto/Industrial Mechanics group ranged from 13.04 (Obedient) to 4.58 (Honest). The means for the Business Education 
TABLE XLIII

SCALE MEANS ON THE ROKEACH INSTRUMENTAL VALUE SURVEY FOR LEVELS OF JOB ASSIGNMENT

\begin{tabular}{|c|c|c|c|c|c|c|c|c|}
\hline $\begin{array}{c}\text { RVS } \\
\text { Scales }\end{array}$ & $\begin{array}{l}\text { Nat. Sci. } \\
\text { Group } 1\end{array}$ & $\begin{array}{l}\text { Soc. Sci. } \\
\text { Group } 2\end{array}$ & $\begin{array}{l}\text { Math } \\
\text { Group } 3\end{array}$ & $\begin{array}{l}\text { English } \\
\text { Group } 4\end{array}$ & $\begin{array}{l}\text { Au/IndMe } \\
\text { Group } 5\end{array}$ & $\begin{array}{l}\text { Bus. Ed. } \\
\text { Group } 6\end{array}$ & $\begin{array}{l}\text { Sec. Sci. } \\
\text { Group } 7\end{array}$ & $\begin{array}{l}\text { Health } \\
\text { Group } 8\end{array}$ \\
\hline Ambitious & 10.531 & 11.516 & 10.733 & 11.217 & 8.160 & 9.596 & 10.467 & 10.158 \\
\hline Broadminded & 9.184 & 7.436 & 8.700 & 8.267 & 10.060 & 10.532 & 9.380 & 9.342 \\
\hline Capable & 7.245 & 7.742 & 7.817 & 8.367 & 7.300 & 8.638 & 6.837 & 6.921 \\
\hline Clean & 13.939 & 13.726 & 13.117 & 15.300 & 10.240 & 11.957 & 13.401 & 12.974 \\
\hline Courageous & 9.347 & 7.581 & 8.583 & 7.500 & 9.500 & 10.000 & 9.685 & 10.250 \\
\hline Forgiving & 9.959 & 9.936 & 9.550 & 9.400 & 8.780 & 9.319 & 8.989 & 10.066 \\
\hline Helpful & 8.918 & 8.484 & 9.333 & 8.250 & 8.980 & 7.468 & 8.772 & 8.592 \\
\hline Honest & 4.245 & 5.936 & 5.467 & 5.333 & 4.580 & 5.638 & 4.380 & 3.934 \\
\hline Imaginative & 10.347 & 9.032 & 10.233 & 8.117 & 11.320 & 10.957 & 11.044 & 10.421 \\
\hline Independent & 7.286 & 8.371 & 6.883 & 7.133 & 9.940 & 7.770 & 8.848 & 7.526 \\
\hline Intellectual & 8.612 & 6.807 & 8.317 & 6.750 & 11.420 & 8.936 & 9.391 & 8.697 \\
\hline Logical & 9.082 & 9.452 & 9.900 & 10.700 & 10.380 & 11.553 & 9.815 & 10.040 \\
\hline Loving & 8.367 & 6.919 & 9.217 & 6.033 & 9.300 & 6.213 & 8.294 & 6.776 \\
\hline Loya 1 & 9.674 & 10.097 & 11.767 & 9.083 & 9.780 & 7.064 & 8.511 & 10.013 \\
\hline Obedient & 15.204 & 15.500 & 15.100 & 15.883 & 13.040 & 14.085 & 14.826 & 16.145 \\
\hline Polite & 12.796 & 13.226 & 12.833 & 12.883 & 11.440 & 12.830 & 12.044 & 12.776 \\
\hline Responsible & 5.878 & 7.677 & 6.900 & 8.117 & 6.560 & 6.404 & 5.522 & 5.263 \\
\hline Self Controlled & 10.306 & 11.565 & 10.967 & 12.417 & 10.480 & 12.277 & 10.891 & 11.105 \\
\hline
\end{tabular}


TABLE XLIV

SCALE STANDARD DEVIATIONS ON THE ROKEACH INSTRUMENTAL VALUE SURVEY FOR LEVELS OF JOB ASSIGNMENT

\begin{tabular}{|c|c|c|c|c|c|c|c|c|}
\hline $\begin{array}{c}\text { RVS } \\
\text { Scales }\end{array}$ & $\begin{array}{l}\text { Nat. Sci. } \\
\text { (Group } 1 \text { ) }\end{array}$ & $\begin{array}{l}\text { Soc. Sci } \\
\text { (Group } 2 \text { ) }\end{array}$ & $\begin{array}{l}\text { Math } \\
\text { (Group 3) }\end{array}$ & $\begin{array}{l}\text { English } \\
\text { (Group 4) }\end{array}$ & $\begin{array}{l}\text { Au/IndMe } \\
\text { (Group 5) }\end{array}$ & $\begin{array}{l}\text { Bus. Ed. } \\
\text { (Group } 6 \text { ) }\end{array}$ & $\begin{array}{l}\text { Sec. Sci. } \\
\text { (Group } 7 \text { ) }\end{array}$ & $\begin{array}{l}\text { Health } \\
\text { (Group 8) }\end{array}$ \\
\hline Ambitious & 5.516 & 5.137 & 5.722 & 4.563 & 5.471 & 5.144 & 5.143 & 5.216 \\
\hline Broadminded & 4.773 & 4.844 & 4.935 & 4.325 & 5.301 & 4.457 & 4.605 & 4.450 \\
\hline Capable & 4.101 & 3.768 & 3.981 & 4.162 & 4.325 & 4.852 & 4.368 & 3.832 \\
\hline Clean & 4.313 & 4.090 & 4.400 & 3.562 & 4.736 & 5.026 & 4.827 & 4.836 \\
\hline Courageous & 4.304 & 4.337 & 4.720 & 4.027 & 5.124 & 4.649 & 4.457 & 4.437 \\
\hline Forgiving & 4.903 & 4.835 & 4.907 & 5.013 & 4.731 & 4.952 & 4.542 & 4.512 \\
\hline Helpful & 4.536 & 4.371 & 4.657 & 4.359 & 5.012 & 4.615 & 4.625 & 4.642 \\
\hline Honest & 3.059 & 4.024 & 4.775 & 4.352 & 4.146 & 4.692 & 3.837 & 3.601 \\
\hline Imaginative & 4.935 & 4.862 & 4.386 & 5.474 & 4.618 & 4.304 & 4.688 & 4.725 \\
\hline Independent & 4.695 & 4.754 & 4.651 & 4.579 & 4.748 & 5.049 & 4.858 & 4.717 \\
\hline Intellectual & 4.729 & 4.898 & 4.485 & 4.905 & 4.887 & 4.494 & 4.876 & 4.836 \\
\hline Logical & 4.271 & 5.168 & 4.387 & 4.717 & 4.936 & 4.169 & 4.718 & 4.626 \\
\hline Loving & 5.203 & 5.196 & 4.187 & 3.551 & 5.028 & 4.899 & 5.512 & 4.810 \\
\hline Loyal & 4.832 & 4.318 & 4.420 & 4.118 & 5.096 & 4.688 & 4.421 & 3.900 \\
\hline Obedient & 3.470 & 4.307 & 4.181 & 3.425 & 5.099 & 4.704 & 4.255 & 3.726 \\
\hline Polite & 4.178 & 3.973 & 3.538 & 3.827 & 4.287 & 4.234 & 3.989 & 3.904 \\
\hline Responsible & 4.241 & 3.966 & 4.587 & 4.076 & 4.639 & 4.266 & 3.708 & 3.568 \\
\hline Self Controlled & 5.124 & 4.412 & 4.650 & 4.102 & 5.250 & 4.466 & 4.887 & $4.40 ?$ \\
\hline
\end{tabular}


group ranged from 14.09 (Obedient) to 5.64 (Honest). The means for the Secretariai science group ranged from 14.83 (Obedient) to 4.38 (Honest). The means for the Health Occupations group ranged from 16.15 (Obedient) to 3.93 (Honest).

A multivariate analysis of variance was performed, using Job Assignment as the independent variable and Rokeach Instrumental Values as dependent variables. With 126 and 3285 degrees of freedom, the Wilks' lambda $(F=2.0494)$ was significant at the .05 level of confidence $(p=.001)$. With the rejection of the statistical hypothesis for the multivariate analysis, univariate analyses of variance were performed on the dependent variables using a .05 level of confidence for each test. The statistical hypothesis that $\mu_{1}=\mu_{2}=\ldots=\mu_{8}$ was rejected for 12 instrumental values (See Table XLV). On each of these 12 variables, a Modified LSD test was performed for each pair-wise mean comparison using a .05 level of confidence. Group means and standard deviations were presented in Tables XLIII and XLIV. A surmary of significant differences between group means is found in Table XLVI. As may be seen, Social Science instructors placed less value on Ambitious than did Auto/Industrial Mechanics instructors. Business Education instructors placed less value on Broadminded than did Social Science instructors. Natural Science, Social Science, Mathematics, English, Secretarial Science, and Health instructors placed less value on Clean than did Auto/Industrial Mechanics instructors, and English instructors placed less value on Clean than did Business Education instructors. Health instructors placed less value on Courageous than did Social Science and English instructors. Auto/Industrial Mechanics and Secretarial Science 
TABLE XLV

ANALYSIS OF VARIANCE TABLE FOR THE JOB ASSIGNMENT VARIABLE USING INSTRUMENTAL VALUES AS DEPENDENT VARIABLES

\begin{tabular}{lrrrrrr}
\hline \multicolumn{1}{c}{ Variable } & Hy SS & Error SS & Hy MS & Error MS & $F^{*}$ & Sig. of F \\
\hline Ambitious & 410.298 & 13360.651 & 58.614 & 27.378 & 2.141 & .038 \\
Broadminded & 377.153 & 10770.234 & 53.879 & 22.070 & 2.441 & .018 \\
Capable & 186.429 & 8467.281 & 26.633 & 17.351 & 1.535 & .153 \\
Clean & 826.734 & 9939.040 & 118.105 & 20.367 & 5.799 & .000 \\
Courageous & 493.706 & 9872.391 & 70.391 & 20.0230 & 3.486 & .001 \\
Forgiving & 98.629 & 11111.363 & 14.090 & 22.769 & 0.619 & .741 \\
Helpful & 115.265 & 10326.985 & 16.466 & 21.162 & 0.778 & .606 \\
Honest & 244.285 & 8066.457 & 34.898 & 16.530 & 2.111 & .041 \\
Imaginative & 504.929 & 11085.101 & 72.133 & 22.715 & 3.176 & .003 \\
Independent & 430.096 & 11043.774 & 61.442 & 22.631 & 2.715 & .009 \\
Intellectual & 870.870 & 11160.484 & 124.410 & 22.870 & 5.440 & .000 \\
Logical & 211.365 & 18495.166 & 30.195 & 37.900 & 0.797 & .590 \\
Loving & 691.654 & 19294.747 & 98.808 & 39.538 & 2.499 & .016 \\
Loyal & 735.092 & 16158.876 & 105.013 & 33.112 & 3.171 & .003 \\
Obedient & 396.938 & 8413.247 & 56.705 & 17.240 & 3.289 & .002 \\
Polite & 134.800 & 7719.296 & 19.257 & 15.818 & 1.217 & .291 \\
Responsible & 475.295 & 8141.730 & 67.899 & 16.684 & 4.070 & .000 \\
Self Control. & 228.749 & 10610.122 & 32.678 & 21.742 & 1.503 & .164 \\
\hline & & & & & & \\
\hline
\end{tabular}


TABLE XLVI

SIGNIFICANT PAIR-WISE MEAN COMPARISONS BETWEEN LEVELS OF JOB ASSIGNMENT* ON THE ROKEACH INSTRUMENTAL VALUES

\begin{tabular}{ll}
\hline RVS Instrumental Scales & Pair-Wise Group Comparisons \\
\hline Ambitious & $2-5$ \\
Broadminded & $2-6$ \\
Clean & $5-1,5-2,5-3,5-4,5-7,5-8$, \\
& $4-6$ \\
Courageous & $2-8,4-8$ \\
Imaginative & $4-5,4-7$ \\
Independent & $3-5$, \\
Intellectual & $2-5,2-7,3-5,4-5,4-7$ \\
Loyal & $3-6,3-7$ \\
Obedient & $5-4,5-8$ \\
Responsible & $2-7,4-7,2-8,4-8$ \\
\hline
\end{tabular}

*Natural Science (1); Social Science (2); Mathematics (3); English (4); Auto/Industrial Mechanics (5); Business Education (6); Secretarial Science (7); and Health (8)

instructors placed less value on being Imaginative than did English instructors. Auto/Industrial Mechanics instructors placed less value on Independent than did Mathematics instructors. Auto/Industrial Mechanics instructors placed less value on the Intellectual scale than did Social Science, Mathematics and English instructors, while Secretarial Science instructors placed less value on Intellectual than did Social Science and English instructors. Mathematics instructors placed less value on 
Loyal than did Business Education and Secretarial Science instructors. Auto/Industrial Mechanics instructors placed greater value on being Obedient than did English and Health instructors. Secretarial Science instructors placed more value on Responsible than did Social Science and English instructors and Health instructors placed more value on Responsible than did Social Science and English instructors. Significant pair-wise mean differences were not found on Honest and Loving.

\section{Values by Sex of Instructor}

Work values, terminal values, and instrumental values were examined by sex of instructor. The results are presented in this section.

Work Values

Scale means and standard deviations for 11 constructs of the OWVI are listed for males and females in Table XLVII. The means for male instructors ranged from 19.36 (Prestige) to 31.31 (Task Satisfaction). For female instructors, the means ranged from 17.64 (Solitude) to 31.32 (Task Satisfaction). A multivariate analysis of variance was performed with sex as the independent variable and the 11 constructs of the OWVI as dependent variables. The $F$ value for Wilks' lambda test was 3.162 ; with 11 and 480 degrees of freedom. This was significant at the .05 level of confidence $(p=.000)$.

With the rejection of the multivariate statistical hypothesis, univariate analyses of variance were performed on the 11 dependent variables (See Table XLVIII). Three statistical hypotheses were rejected at the .05 level of confidence. Significant differences were 
TABLE XLVII

MEANS AND STANDARD DEVIATION FOR THE SCALES OF THE OWVI FOR MALE AND FEMALE INSTRUCTORS

\begin{tabular}{|c|c|c|c|c|c|c|}
\hline \multirow[t]{2}{*}{ Value } & \multicolumn{2}{|c|}{ Male } & \multicolumn{2}{|c|}{ Female } & \multicolumn{2}{|c|}{ Total } \\
\hline & Mean & S.D. & Mean & S.D. & Mean & S.D. \\
\hline Altruism & 27.73 & 5.52 & 27.38 & 5.06 & 27.44 & 5.33 \\
\hline Object Orientation & 20.06 & 6.99 & 18.02 & 6.46 & 19.16 & 6.83 \\
\hline Security & 24.43 & 6.77 & 24.99 & 6.21 & 24.68 & 6.54 \\
\hline Control & 20.86 & 6.67 & 21.00 & 6.21 & 20.95 & 6.47 \\
\hline Self Realization & 30.50 & 3.75 & 30.73 & 4.29 & 30.64 & 3.99 \\
\hline Independence & 27.45 & 4.79 & 26.86 & 4.57 & 27.19 & 4.69 \\
\hline Money & 23.46 & 6.16 & 23.62 & 6.80 & 23.48 & 7.04 \\
\hline Task Satisfaction & 31.31 & 4.08 & 31.32 & 4.62 & 31.33 & 4.31 \\
\hline Solitude & 19.49 & 5.57 & 17.64 & 5.65 & 18.67 & 5.67 \\
\hline Ideas/Data. & 28.37 & 4.27 & 27.06 & 5.02 & 27.81 & 4.68 \\
\hline Prestige & 19.36 & 6.43 & 18.76 & 6.28 & 19.03 & 6.37 \\
\hline
\end{tabular}

found on Object Orientation, Solitude, and Ideas/Data with male instructors placing more value on all three variables than did female instructors.

\section{RVS Terminal Values}

Male and female scale means and standard deviations of the ranks of the 18 terminal values are listed in Table IL. For the males, the means ranged from a low of 13.35 (National Security) to a high of 5.57 
TABLE XLVIII

ANALYSIS OF VARIANCE TABLE FOR SEX USING WORK VALUES AS DEPENDENT VARIABLES

\begin{tabular}{|c|c|c|c|c|c|c|}
\hline Variable & Hy SS & Error SS & Hy MS & Error MS & $F^{\star}$ & Sig. of $F$ \\
\hline Altruism & 31.650 & 13848.537 & 31.650 & 28.262 & 1.180 & .290 \\
\hline Object Orient. & 509.716 & 22340.967 & 509.716 & 45.594 & 11.189 & .001 \\
\hline Security & 38.672 & 20831.125 & 38.672 & 42.813 & 0.910 & .341 \\
\hline Control & 2.494 & 204576.571 & 2.494 & 41.789 & 0.060 & .807 \\
\hline Self Realiz. & 6.469 & 7855.035 & 6.469 & 16.031 & 0.404 & .526 \\
\hline Independence & 42.926 & 10769.334 & 42.926 & 21.978 & 1.953 & .163 \\
\hline Money & 3.310 & 23977.233 & 3.310 & 48.933 & 0.068 & .795 \\
\hline Task Satis. & 0.042 & 9203.755 & 0.042 & 18.783 & 0.002 & .962 \\
\hline Solitude & 418.587 & 15388.454 & 418.587 & 31.405 & 13.329 & .000 \\
\hline Ideas/Data & 207.359 & 10508.761 & 207.259 & 21.446 & 9.669 & .002 \\
\hline Prestige & 44.061 & 19824.686 & 44.061 & 40.458 & 1.089 & .297 \\
\hline \multicolumn{7}{|c|}{$\begin{array}{l}\text { (Health). The means for females ranged from } 13.29 \text { (Social Recognition) } \\
\text { to } 5.39 \text { (Self Respect). A multivariate analysis of variance was per- } \\
\text { formed with sex as the independent variable and the terminal scales of } \\
\text { the RVS as the dependent variables. The } F \text { value for Wilks' lambda test } \\
\text { was } 2.393 \text { with } 18 \text { and } 472 \text { degrees of freedom; this was significant at } \\
\text { the } .05 \text { level of confidence }(p=.001) \text {. }\end{array}$} \\
\hline
\end{tabular}


TABLE IL

MEANS AND STANDARD DEVIATIONS FOR THE TERMINAL VALUES OF THE RVS FOR MALE AND FEMALE FACULTY

\begin{tabular}{|c|c|c|c|c|c|c|}
\hline \multirow[t]{2}{*}{ Variable } & \multicolumn{2}{|c|}{ Male } & \multicolumn{2}{|c|}{ Fema le } & \multicolumn{2}{|c|}{ Total } \\
\hline & Means & S.D. & Means & S.D. & Means & S.D. \\
\hline A Comfortable Life & 11.06 & 4.66 & 12.04 & 4.46 & 11.47 & 4.60 \\
\hline An Exciting Life & 10.20 & 4.87 & 11.31 & 4.30 & 10.68 & 4.66 \\
\hline A Sense of Accomp. & 7.61 & 4.46 & 7.94 & 4.64 & 7.74 & 4.53 \\
\hline A World at Peace & 10.28 & 5.10 & 9.66 & 5.10 & 10.02 & 5.10 \\
\hline A World of Beauty & 11.30 & 4.60 & 11.17 & 4.08 & 11.25 & 4.22 \\
\hline Equality & 11.33 & 4.60 & 10.86 & 4.31 & 11.13 & 4.46 \\
\hline Family Security & 6.19 & 4.53 & 6.94 & 4.66 & 6.54 & 4.59 \\
\hline Freedom & 7.08 & 4.14 & 6.86 & 4.07 & 6.95 & 4.10 \\
\hline Health & 5.57 & 3.82 & 5.95 & 3.99 & 5.73 & 3.90 \\
\hline Inner Harmony & 7.20 & 4.41 & 7.28 & 4.57 & 7.24 & 4.48 \\
\hline Mature Love & 8.76 & 4.44 & 8.27 & 4.60 & 8.57 & 4.52 \\
\hline National Security & 13.35 & 4.36 & 12.87 & 4.72 & 13.13 & 4.53 \\
\hline Pleasure & 12.48 & 4.06 & 12.58 & 4.34 & 12.54 & 4.17 \\
\hline Salvation & 12.05 & 6.77 & 12.13 & 6.67 & 12.14 & 6.70 \\
\hline Self Respect & 6.18 & 4.14 & 5.39 & 3.81 & 5.85 & 4.02 \\
\hline Social Recognition & 13.08 & 3.79 & 13.29 & 3.90 & 13.18 & 3.85 \\
\hline True Friendship & 9.61 & 4.13 & 8.24 & 4.17 & 8.97 & 4.18 \\
\hline Wisdom & 7.54 & 4.79 & 8.17 & 4.91 & 7.78 & 4.85 \\
\hline
\end{tabular}


With the rejection of the statistical hypothesis for the multivariate analysis, univariate analyses of variance were performed on the 18 dependent variables (See Table L). Four statistical hypotheses that $\mu_{1}=\mu_{2}$ were rejected at the .05 level of confidence. Significant differences were found on the values of A Comfortable Life, An Exciting Life, Self Respect and True Friendship, with female instructors placing more value on Self Respect and True Friendship while male instructors placed more value on A Comfortable Life and An Exciting Life. 
TABLE L

ANALYSIS OF VARIANCE TABLE FOR SEX USING RVS

TERMINAL VALUES AS DEPENDENT VARIABLES

\begin{tabular}{lrrrrrrr}
\hline \multicolumn{1}{c}{ Variable } & Hy SS & Error SS & Hy MS & Error MS & F* & Sig. of F \\
\hline A Comfort. Life & 117.013 & 10199.676 & 117.013 & 20.858 & 5.610 & .018 \\
An Exciting Life & 134.480 & 10434.204 & 134.480 & 21.338 & 6.302 & .012 \\
A Sense of Accom. & 12.184 & 10102.267 & 12.184 & 20.659 & 0.590 & .443 \\
A World at Peace & 46.979 & 12707.970 & 46.979 & 25.988 & 1.808 & .179 \\
A World of Beauty & 1.923 & 8767.719 & 1.923 & 17.930 & 0.107 & .743 \\
Equality & 26.932 & 9767.907 & 26.932 & 19.975 & 1.348 & .246 \\
Family Security & 70.004 & 10316.192 & 70.004 & 21.097 & 2.218 & .069 \\
Freedom & 6.574 & 8257.295 & 6.574 & 16.886 & 0.389 & .533 \\
Health & 18.463 & 7431.687 & 18.463 & 15.198 & 1.215 & .271 \\
Inner Harmony & 0.393 & 9798.291 & 0.393 & 20.037 & 0.020 & .889 \\
Mature Love & 30.402 & 9983.406 & 30.402 & 20.416 & 1.489 & .223 \\
National Security & 27.577 & 10027.339 & 27.577 & 20.506 & 1.345 & .246 \\
Pleasure & 1.439 & 8584.993 & 1.439 & 17.556 & 0.082 & .775 \\
Salvation & 0.707 & 22172.169 & 0.707 & 45.342 & 0.016 & .901 \\
Self Respect & 77.928 & 7786.301 & 77.928 & 15.923 & 4.894 & .027 \\
Social Recogn. & 5.329 & 7216.899 & 5.329 & 14.758 & 0.361 & .548 \\
True Friendship & 232.267 & 8415.603 & 232.267 & 17.210 & 13.496 & .000 \\
Wisdom & 49.349 & 11495.588 & 49.349 & 23.508 & 2.099 & .148 \\
\hline & & & & & & \\
\hline
\end{tabular}

$\star_{\mathrm{df}}=1$ and 489 
RVS Instrumental Values

Scale means and standard deviations of the ranks of the 18 instrumental values are listed for males and females in Table LI. For Males, the values ranged from a low of 14.90 (Obedient) to a high of 4.62

(Honest). The values ranged, for female, from a low of 15.19 (Obedient) to a high of 5.20 (Honest).

A multivariate analysis of variance was performed with sex as the independent variable and the instrumental scales of the RVS aS dependent variables. The $F$ value for Wilks' lambda test was 2.092 ; with 18 and 471 degrees of freedom; this was significant at the .05 level $(p=.005)$.

With the rejection of the statistical hypothesis for the multivariate analysis, univariate analyses of variance were performed on the 18 dependent variables (See Table LII). Three statistical hypotheses were rejected at the .05 level. Significant differences were found on the values of Loving, Loyal, and Self Control with female instructors placing greater value on Loving and Loyal and less value on Self Control than did male instructors. 
TABLE LI

MEANS AND STANDARD DEVIATIONS FOR THE INSTRUMENTAL VALUES OF THE RVS FOR MALE AND FEMALE FACULTY

\begin{tabular}{|c|c|c|c|c|c|c|}
\hline \multirow[t]{2}{*}{ Variable } & \multicolumn{2}{|c|}{ Male } & \multicolumn{2}{|c|}{ Fema le } & \multicolumn{2}{|c|}{ Total } \\
\hline & Means & S.D. & Means & S.D. & Means & Total \\
\hline Ambitious & 10.24 & 5.47 & 10.50 & 5.06 & 10.36 & 5.27 \\
\hline Broadminded & 8.82 & 4.91 & 9.33 & 4.51 & 9.07 & 4.74 \\
\hline Capable & 7.53 & 4.16 & 7.53 & 4.23. & 7.52 & 4.18 \\
\hline Clean & 13.07 & 4.59 & 13.36 & 4.71 & 13.17 & 4.66 \\
\hline Courageous & 9.14 & 4.64 & 8.99 & 4.54 & 9.10 & 4.58 \\
\hline Forgiving & 9.58 & 4.86 & 9.35 & 4.63 & 9.50 & 4.76 \\
\hline Helpful & 8.54 & 4.59 & 8.69 & 4.60 & 8.62 & 4.60 \\
\hline Honest & 4.62 & 3.74 & 5.20 & 4.50 & 4.87 & 4.10 \\
\hline Imaginative & 9.93 & 4.78 & 10.58 & 4.86 & 10.19 & 4.84 \\
\hline Independent & 8.02 & 4.82 & 7.97 & 4.84 & 7.99 & 4.83 \\
\hline Intellectual & 8.66 & 5.16 & 8.48 & 4.66 & 8.58 & 4.93 \\
\hline Logical & 9.64 & 4.70 & 10.19 & 4.79 & 10.06 & 4.75 \\
\hline Loving & 8.29 & 5.08 & 6.40 & 4.81 & 7.65 & 4.95 \\
\hline Loyal & 9.81 & 4.52 & 8.76 & 4.57 & 9.50 & 4.54 \\
\hline Obedient & 14.90 & 4.19 & 15.19 & 4.29 & 15.05 & 4.22 \\
\hline Polite & 12.62 & 3.92 & 12.55 & 4.00 & 12.59 & 3.98 \\
\hline Responsible & 6.60 & 4.27 & 6.19 & 3.99 & 6.45 & 4.17 \\
\hline Self Control & 10.85 & 4.85 & 11.75 & 4.36 & 11.22 & 4.68 \\
\hline
\end{tabular}


TABLE LII

ANALYSIS OF VARIANCE TABLE FOR MALE AND FEMALE INSTRUCTORS USING INSTRUMENTAL VALUES AS DEPENDENT VARIABLES

\begin{tabular}{|c|c|c|c|c|c|c|}
\hline Variable & Hy SS & Error SS & Hy MS & Error MS & $F^{\star}$ & Sig. of $F$ \\
\hline Ambitious & 7.610 & 13644.000 & 7.610 & 27.959 & 0.272 & .602 \\
\hline Broadminded & 31.736 & 10920.427 & 31.736 & 22.378 & 1.418 & .234 \\
\hline Capable & 0.026 & 8607.738 & 0.026 & 17.639 & 0.001 & .970 \\
\hline Clean & 9.990 & 10547.602 & 9.990 & 21.614 & 0.462 & .497 \\
\hline Courageous & 2.202 & 1307.081 & 2.202 & 21.121 & 0.140 & .747 \\
\hline Forgiving & 6.909 & 11025.246 & 6.909 & 22.593 & 0.306 & .581 \\
\hline Helpful & 2.553 & 10245.773 & 2.553 & 20.995 & 0.122 & .727 \\
\hline Honest & 37.957 & 8246.525 & 37.957 & 16.899 & 2.246 & .135 \\
\hline Imaginative & 50.506 & 11338.972 & 50.506 & 23.236 & 2.174 & .141 \\
\hline Independent & 0.796 & 11393.171 & 0.796 & 23.347 & 0.034 & .854 \\
\hline Intellectual & 5.033 & 11855.335 & 5.033 & 24.294 & 0.207 & .649 \\
\hline Logical & 5.329 & 18581.724 & 5.329 & 38.077 & 0.140 & .708 \\
\hline Loving & 609.595 & 19257.173 & 609.595 & 39.461 & 15.448 & .000 \\
\hline Loyal & 231.580 & 16592.912 & 231.580 & 34.002 & 6.811 & .009 \\
\hline Obedient & 8.822 & 8764.361 & 8.822 & 17.960 & 0.491 & .484 \\
\hline Polite & 0.630 & 7653.738 & 0.630 & 15.684 & 0.040 & .841 \\
\hline Responsible & 22.613 & 8410.940 & 22.613 & 17.236 & 1.312 & .253 \\
\hline Self Control & 92.754 & 10471.499 & 92.754 & 21.458 & 4.323 & .038 \\
\hline
\end{tabular}

${ } \mathrm{df}=1$ and 488 
Values by Number of Years Teaching

Work values, terminal values, and instrumental values were examined by number of years of teaching $(0-4,5-9,10-14,15-19,20$ \& over). The following factors were considered in the decision to use these categories of teaching experience: (1) to obtain a limited number of categories for the statistical analysis; (2) to somewhat balance the number of people in each category; (3) to use the same interval size (in so far as possible) for each category; and (4) to have categories that reflect considerable experience and limited experience. The results are presented in this section.

Work Values

Scale means and standard deviations of the OWVI are presented in Tables LIII \& LIV for the five categories of teaching experience. For instructors with less than five years experience, the means ranged from 19.74 (Solitude) to 30.73 (Task Satisfaction). For those with 5-9 years of experience, the means ranged from 18.57 (Solitude) to 30.68 (Task Satisfaction). For the 10-14 years of experience group, the means ranged from 18.80 (Solitude) to 31.60 (Task Satisfaction). For the 1519 years group, the means ranged from 18.23 (Prestige) to 31.96 (Task Satisfaction). For the 20 years and more group, the means ranged from 16.23 (Object Orientation) to 32.25 (Task Satisfaction). 
TABLE LIII

SCALE MEANS ON THE OHIO WORK VALUES INVENTORY FOR THE LEVELS OF TEACHING EXPERIENCE

\begin{tabular}{lccccc}
\hline \multicolumn{1}{c}{ Value } & $\begin{array}{c}0-4 \\
\text { (Group 1) }\end{array}$ & $\begin{array}{c}5-9 \\
\text { (Group 2) }\end{array}$ & $\begin{array}{c}10-14 \\
\text { (Group 3) }\end{array}$ & $\begin{array}{c}15-19 \\
\text { (Group 4) }\end{array}$ & $\begin{array}{c}20 \text { \& Over } \\
\text { (Group 5) }\end{array}$ \\
\hline Altruism & 27.23 & 26.89 & 27.27 & 28.03 & 28.31 \\
Object Orientation & 20.40 & 19.72 & 19.33 & 18.58 & 16.23 \\
Security & 24.84 & 24.18 & 25.89 & 23.89 & 24.64 \\
Control & 22.38 & 20.91 & 21.18 & 20.96 & 18.98 \\
Self Realization & 30.20 & 30.01 & 30.56 & 31.77 & 31.25 \\
Independence & 26.64 & 26.91 & 27.70 & 27.66 & 27.00 \\
Money & 24.50 & 23.28 & 24.25 & 22.63 & 22.25 \\
Task Satisfaction & 30.73 & 30.68 & 31.60 & 31.96 & 32.25 \\
Solitude & 19.74 & 18.57 & 18.80 & 18.52 & 17.48 \\
Ideas/Data & 26.95 & 27.28 & 28.04 & 28.66 & 28.63 \\
Prestige & 19.75 & 19.19 & 19.93 & 18.23 & 17.28 \\
\hline
\end{tabular}


TABLE LIV

SCALE STANDARD DEVIATIONS ON THE OHIO WORK VALUES INVENTORY FOR LEVELS OF TEACHING EXPERIENCE

\begin{tabular}{lccccc}
\hline \multicolumn{1}{c}{ Value } & $\begin{array}{c}0-4 \\
\text { (Group 1) }\end{array}$ & $\begin{array}{c}5-9 \\
\text { (Group 2) }\end{array}$ & $\begin{array}{c}10-14 \\
\text { (Group 3) }\end{array}$ & $\begin{array}{c}15-19 \\
\text { (Group 4) }\end{array}$ & $\begin{array}{c}\text { 20 \& Over } \\
\text { (Group 5) }\end{array}$ \\
\hline Altruism & 4.42 & 5.32 & 5.87 & 5.55 & 5.26 \\
Object Orientation & 7.39 & 6.47 & 6.57 & 7.01 & 6.27 \\
Security & 6.29 & 6.16 & 6.20 & 6.99 & 7.14 \\
Control & 5.98 & 6.37 & 6.38 & 6.35 & 7.43 \\
Self Realization & 4.28 & 4.21 & 4.09 & 3.27 & 3.36 \\
Independence & 4.48 & 4.49 & 4.76 & 4.79 & 5.27 \\
Money & 6.33 & 6.56 & 7.15 & 7.53 & 8.30 \\
Task Satisfaction & 4.37 & 4.77 & 4.34 & 3.68 & 3.56 \\
Solitude & 5.81 & 5.28 & 5.74 & 5.94 & 5.75 \\
Ideas/Data & 4.21 & 4.62 & 4.62 & 4.66 & 5.36 \\
Prestige & 6.52 & 6.09 & 6.57 & 5.43 & 7.23 \\
\hline
\end{tabular}

A multivariate analysis of variance was performed, using Number of Years Teaching as the independent variable and work values as dependent variables. With 44 and 1898 degrees of freedom, the Wilks' lambda value $(F=1.5064)$ was significant at the .05 level of confidence $(p=.019)$. With the rejection of the statistical hypothesis for the multivariate analysis, univariate analyses of variance were performed on the dependent variables, using a .05 level of confidence for each test. The 
statistical hypothesis that $\mu_{1}=\mu_{2}=\ldots .=\mu_{5}$ was rejected for six work values (See Table LV). On each of these six variables, a modified LSD was performed for each pair-wise mean comparison using an .05 leve 1 of confidence. Group means and standard deviations were presented in Tables LIII and LIV. A summary of significant differences between group means is found in Table LVI. As may be seen, instructors in Group 5 (teaching over 20 years) placed less emphasis on Object Orientation than did instructors in Groups 1 (0-4 years teaching), 2 (5-9 years teaching) and $3(10-14$ years teaching). Group 5 instructors also placed less emphasis on Control than did instructors in Group 1, and instructors in Group 2 placed less emphasis on Self Realization than did instructors in Group 4 (15-19 years teaching). Significant pair-wise differences were not found on Task Satisfaction, Ideas/Data, and Prestige. 
TABLE LV

ANALYSIS OF VARIANCE TABLE FOR THE LEVELS OF TEACHING EXPERIENCE USING WORK VALUES AS DEPENDENT VARIABLES

\begin{tabular}{lrrrrrrr}
\hline \multicolumn{1}{c}{ Variable } & Hy SS & Error SS & Hy MS & Error MS & $F^{*}$ & Sig. of F \\
\hline Altruism & 124.814 & 13790.742 & 31.203 & 28.276 & 1.100 & .356 \\
Object Orient. & 764.174 & 22024.415 & 191.178 & 45.318 & 4.219 & .002 \\
Security & 249.646 & 20504.004 & 62.411 & 42.189 & 1.479 & .207 \\
Control & 440.446 & 20188.536 & 110.112 & 41.540 & 2.651 & .033 \\
Self Realization & 192.592 & 7637.563 & 48.148 & 15.715 & 3.064 & .016 \\
Independence & 86.986 & 10759.319 & 21.747 & 22.139 & 0.982 & .417 \\
Money & 319.467 & 24149.278 & 79.867 & 49.690 & 1.607 & .171 \\
Task Satisfaction & 187.255 & 8988.954 & 46.806 & 18.496 & 2.531 & .040 \\
Solitude & 199.690 & 15516.485 & 49.923 & 31.927 & 1.564 & .183 \\
Ideas/Data & 211.317 & 10528.589 & 52.829 & 21.664 & 2.439 & .046 \\
Prestige & 384.842 & 19611.370 & 96.210 & 40.353 & 2.384 & .050 \\
\hline
\end{tabular}

$\star_{\mathrm{d} f}=4$ and 486 
TABLE LVI

SIGNIFICANT PAIR-WISE MEAN COMPARISONS BETWEEN LEVELS OF

TEACHING EXPERIENCE ON THE OHIO WORK VALUES INVENTORY

\begin{tabular}{ll}
\hline \multicolumn{1}{c}{ OWVI Scales } & Pair-Wise Group Comparisons* \\
\hline Object Orientation & $5-1,5-2,5-3$ \\
Control & $5-1$ \\
Self Realization & $2-4$ \\
\hline
\end{tabular}

*Number of years teaching : $0-4$ (1); 5-9 (2); 10-14 (3); 15-19 (4); 20 and over (5)

\section{Rokeach Terminal Values}

Each faculty member ranked the 18 Rokeach Terminal Scales. Scales means and standard deviations of the ranks are presented in Tables LVII and LVIII for the various categories of teaching experience. The means of $0-4$ years of teaching experience group ranged from a low of 13.40 (Social Recognition) to a high of 5.83 (Health). For the 5-9 years of experience group, the means ranged from a low of 13.03 (Salvation and National Security) to a high of 6.05 (Health). For the 10-14 years of experience group, the means ranged from 13.28 (Social Recognition) to 5.85 (Health). For the 15-19 years groups, the range was 13.86 (National Security) to 4.66 (Self Respect). For the most experienced group (20 \& over), the range was 13.48 (National Security) to 5.06 (Self Respect). 
TABLE LVII

SCALE MEANS ON THE ROKEACH TERMINAL VALUES SURVEY FOR THE LEVELS OF TEACHING EXPERIENCE

\begin{tabular}{lrrrrr}
\hline \multicolumn{1}{c}{ RVS Scales } & $\begin{array}{c}0-4 \\
\text { (Group 1) }\end{array}$ & $\begin{array}{c}5-9 \\
\text { (Group 2) }\end{array}$ & $\begin{array}{c}10-14 \\
\text { (Group 3) }\end{array}$ & $\begin{array}{c}15-19 \\
\text { (Group 4) }\end{array}$ & $\begin{array}{c}\text { 20 \& Over } \\
\text { (Group 5) }\end{array}$ \\
\hline A Comfortable Life & 10.95 & 11.39 & 11.92 & 11.34 & 11.44 \\
An Exciting Life & 10.22 & 10.62 & 10.57 & 11.90 & 10.50 \\
A Sense of Accomp. & 8.07 & 8.15 & 7.53 & 7.62 & 6.88 \\
A World at Peace & 10.38 & 9.56 & 10.25 & 10.12 & 10.14 \\
A World of Beauty & 11.49 & 11.06 & 11.13 & 11.71 & 11.25 \\
Equality & 11.64 & 10.76 & 11.01 & 11.81 & 10.83 \\
Family Security & 6.32 & 7.25 & 6.02 & 6.64 & 5.95 \\
Freedom & 7.05 & 7.45 & 7.07 & 5.92 & 6.89 \\
Health & 5.83 & 6.05 & 5.85 & 4.73 & 5.83 \\
Inner Harmony & 7.25 & 6.81 & 7.42 & 6.58 & 8.63 \\
Mature Love & 7.94 & 8.05 & 8.48 & 10.11 & 9.00 \\
National Security & 12.77 & 13.03 & 12.95 & 13.86 & 13.48 \\
Pleasure & 11.32 & 12.23 & 12.87 & 13.63 & 13.02 \\
Salvation & 10.99 & 13.03 & 12.19 & 11.18 & 12.50 \\
Self Respect & 6.74 & 6.15 & 5.98 & 4.66 & 5.06 \\
Social Recognition & 13.40 & 12.52 & 13.28 & 13.27 & 12.92 \\
True Friendship & 9.75 & 8.62 & 9.01 & 8.95 & 8.94 \\
Wisdom & 8.85 & 8.21 & 7.47 & 7.00 & 6.86 \\
\hline & & & & & \\
\hline
\end{tabular}


TABLE LVIII

SCALE STANDARD DEVIATIONS ON THE ROKEACH TERMINAL VALUES SCALE FOR THE LEVELS OF TEACHING EXPERIENCE

\begin{tabular}{lccccc}
\hline \multicolumn{1}{c}{ RVS Scales } & $\begin{array}{c}0-4 \\
\text { (Group } 1)\end{array}$ & $\begin{array}{c}5-9 \\
\text { (Group } 2)\end{array}$ & $\begin{array}{c}10-14 \\
\text { (Group } 3)\end{array}$ & $\begin{array}{c}15-19 \\
\text { (Group } 4)\end{array}$ & $\begin{array}{c}\text { 20 \& Over } \\
\text { (Group 5) }\end{array}$ \\
\hline A Comfortable Life & 4.71 & 4.71 & 4.75 & 4.35 & 4.32 \\
An Exciting Life & 4.56 & 4.63 & 4.83 & 4.21 & 4.94 \\
A Sense of Accomp. & 4.83 & 4.54 & 4.55 & 4.23 & 4.39 \\
A World at Peace & 4.71 & 5.13 & 5.23 & 5.03 & 5.58 \\
A World of Beauty & 4.23 & 4.05 & 4.24 & 4.42 & 4.42 \\
Equality & 4.90 & 4.42 & 4.28 & 4.40 & 4.26 \\
Family Security & 4.85 & 4.89 & 4.21 & 4.72 & 3.84 \\
Freedom & 4.04 & 4.33 & 3.83 & 3.70 & 4.49 \\
Health & 4.47 & 4.26 & 3.59 & 2.81 & 3.75 \\
Inner Harmony & 4.68 & 4.37 & 4.66 & 4.29 & 4.14 \\
Mature Love & 4.28 & 4.65 & 4.25 & 4.51 & 4.55 \\
National Security & 4.80 & 4.66 & 4.79 & 3.61 & 4.45 \\
Pleasure & 4.16 & 4.74 & 3.92 & 3.41 & 3.71 \\
Salvation & 6.46 & 6.38 & 6.82 & 7.78 & 6.78 \\
Self Respect & 4.24 & 4.43 & 3.93 & 2.82 & 3.67 \\
Social Recognition & 4.18 & 4.05 & 3.95 & 3.37 & 3.21 \\
True Friendship & 4.29 & 4.27 & 4.38 & 3.47 & 4.28 \\
Wisdom & 5.44 & 4.83 & 4.84 & 4.43 & 4.18 \\
\hline & & & & & \\
\hline
\end{tabular}


A multivariate analysis of variance was performed, using Number of Years Teaching as the independent variable and the terminal values as dependent variables. With 72 and 1866 degrees of freedom, the Wilks' lambda value $(F=1.4418)$ was significant at the .05 level of confidence $(p=.012)$. With the rejection of the statistical hypothesis for the multivariate analysis, univariate analyses of variance were performed on the dependent variables using a .05 level of confidence for each test. The statistical hypothesis that $\mu_{1}=\mu_{2}=\ldots .=\mu_{5}$ was rejected for four terminal values (See Table LIX). On each of these four values, a Modified LSD was performed for each pair-wise mean comparison using a .05 level of confidence. Group means and standard deviations were presented in Tables LVII and LVIII. As may be seen in Table LX, instructors in Group 4 (15-19 years teaching) valued Mature Love less than did Group 1 (0-4 years teaching) and 2 (5-9 years teaching). Group 4 (15-19 yrs.) valued Pleasure less than did Group 1 (0-4 yrs.) and Group 1 (0-4 yrs.) valued Self Respect less than did Group 4 (15-19 yrs.). Significant pair-wise mean differences were not found on Wisdom. 
TABLE LIX

ANALYSIS OF VARIANCE TABLE FOR THE NUMBER OF YEARS TEACHING VARIABLE USING TERMINAL VALUES AS DEPENDENT VARIABLES

\begin{tabular}{lrrrrrr} 
Variable & Hy SS & Error SS & Hy MS & Error MS & F* & Sig. of F \\
\hline A Comfort. Life & 49.896 & 10350.104 & 12.747 & 21.340 & 0.585 & .674 \\
An Exciting Life & 132.681 & 10466.586 & 33.170 & 21.581 & 1.537 & .190 \\
A Sense of Accomp. & 88.602 & 9972.998 & 22.151 & 20.563 & 1.077 & .367 \\
A World at Peace & 51.219 & 12721.191 & 12.805 & 26.229 & 0.488 & .744 \\
A World of Beauty & 27.273 & 8685.423 & 6.818 & 17.908 & 0.381 & .822 \\
Equality & 84.879 & 9634.245 & 21.220 & 19.883 & 0.167 & .372 \\
Family Security & 132.990 & 10163.110 & 33.248 & 20.955 & 1.587 & .177 \\
Freedom & 116.625 & 8138.275 & 29.156 & 16.780 & 1.738 & .140 \\
Health & 91.531 & 7381.979 & 22.883 & 15.221 & 1.503 & .200 \\
Inner Harmony & 185.997 & 9638.542 & 46.499 & 19.873 & 2.340 & .054 \\
Mature Love & 262.920 & 9637.864 & 65.730 & 19.872 & 3.308 & .011 \\
National Security & 64.316 & 10040.396 & 16.079 & 20.702 & 0.777 & .541 \\
Pleasure & 265.894 & 8290.475 & 66.474 & 17.094 & 3.889 & .004 \\
Salvation & 313.162 & 21707.320 & 78.291 & 44.757 & 1.749 & .138 \\
Self Respect & 231.400 & 7672.600 & 57.850 & 15.820 & 3.657 & .006 \\
Social Recog. & 104.650 & 7214.934 & 26.162 & 14.876 & 1.759 & .136 \\
True Friendship & 73.488 & 8496.439 & 18.372 & 17.519 & 1.049 & .381 \\
Wisdom & 241.974 & 11258.426 & 60.493 & 23.213 & 2.606 & .035 \\
\hline & & & & & & \\
\hline
\end{tabular}

$\star_{\mathrm{df}}=4$ and 485 
TABLE LX

SIGNIFICANT PAIR-WISE MEAN COMPARISONS BETWEEN LEVELS OF TEACHING EXPERIENCE ON THE ROKEACH TERMINAL VALUES

\begin{tabular}{ll}
\hline \multicolumn{1}{l}{ RVS Terminal Scales } & Pair-wise Group Comparisons* \\
\hline Mature Love & $1-4,2-4$ \\
Pleasure & $1-4$ \\
Self Respect & $1-4$ \\
\hline
\end{tabular}

*Number of years teaching: $0-4$ (1); 5-9 (2); 10-14 (3); 15-19 (4); 20 and over (5)

\section{Rokeach Instrumental Values}

Scale means and standard deviations of the ranks of the Rokeach Instrumental Values for various categories of teaching experience are presented in Tables LXI and LXII. The means of the $0-4$ years of experience group ranged from a low of 14.13 (Obedient) to 5.25 (Honest). For the 5-9 years group, the means ranged from 15.01 (Obedient) to 5.46 (Honest). The means for the 10-14 years group ranged from a low of 15.39 (Obedient) to a high of 4.80 (Honest). For the 15-19 years group the means ranged from 15.44 (Obedient) to 4.08 (Honest). For the over 19 years of experience, the means ranged from 15.21 (Obedient) to 4.24 (Honest). 
TABLE LXI

SCALE MEANS ON THE ROKEACH INSTRUMENTAL VALUES SURVEY FOR THE LEVELS OF TEACHING EXPERIENCE

\begin{tabular}{|c|c|c|c|c|c|}
\hline RVS Scales & $\begin{array}{c}0-4 \\
\text { (Group 1) }\end{array}$ & $\begin{array}{c}5-9 \\
\text { (Group 2) }\end{array}$ & $\begin{array}{c}10-14 \\
\text { (Group 3) }\end{array}$ & $\begin{array}{c}15-19 \\
(\text { Group 4) }\end{array}$ & $\begin{array}{l}20 \text { \& Over } \\
\text { (Group 5) }\end{array}$ \\
\hline Ambitious & 10.29 & 10.37 & 10.29 & 10.21 & 10.67 \\
\hline Broadminded & 9.01 & 8.91 & 8.97 & 9.56 & 9.27 \\
\hline Capable & 7.42 & 7.73 & 7.04 & 6.78 & 8.10 \\
\hline Clean & 11.29 & 13.25 & 13.65 & 13.41 & 14.37 \\
\hline Courageous & 8.83 & 8.85 & 8.23 & 8.84 & 8.89 \\
\hline Forgiving & 9.49 & 8.78 & 9.90 & 10.62 & 9.21 \\
\hline Helpful & 8.75 & 8.85 & 8.23 & 8.84 & 8.49 \\
\hline Honest & 5.25 & 5.46 & 4.80 & 4.08 & 4.24 \\
\hline Imaginative & 10.99 & 9.68 & 10.46 & 10.36 & 10.06 \\
\hline Independent & 8.62 & 8.27 & 8.10 & 6.60 & 7.79 \\
\hline Intel lectual & 9.00 & 8.71 & 8.74 & 8.59 & 7.67 \\
\hline Logical & 10.48 & 10.86 & 9.40 & 9.55 & 9.68 \\
\hline Loving & 7.84 & 7.20 & 7.29 & 8.55 & 8.11 \\
\hline Loyal & 10.11 & 9.54 & 9.27 & 9.49 & 8.97 \\
\hline Obedient & 14.13 & 15.01 & 15.39 & 15.44 & 15.21 \\
\hline Polite & 11.97 & 12.25 & 12.63 & 12.82 & 13.64 \\
\hline Responsible & 6.39 & 6.82 & 6.46 & 5.86 & 6.33 \\
\hline Self Controlled & 11.08 & 11.68 & 11.14 & 11.44 & 10.33 \\
\hline
\end{tabular}


TABLE LXII

SCALE STANDARD DEVIATIONS ON THE ROKEACH INSTRUMENTAL

VALUES SURVEY FOR THE LEVELS OF TEACHING EXPERIENCE

\begin{tabular}{|c|c|c|c|c|c|}
\hline RVS Scales & $\begin{array}{c}0-4 \\
\text { (Group 1) }\end{array}$ & $\begin{array}{c}5-9 \\
\text { (Group 2) }\end{array}$ & $\begin{array}{c}10-14 \\
\text { (Group 3) }\end{array}$ & $\begin{array}{c}15-19 \\
\text { (Group 4) }\end{array}$ & $\begin{array}{l}20 \text { \& Over } \\
\text { (Group 5) }\end{array}$ \\
\hline Ambitious & 5.29 & 5.41 & 4.97 & 5.46 & 5.46 \\
\hline Broadminded & 4.81 & 4.70 & 4.72 & 4.92 & 4.69 \\
\hline Capable & 4.41 & 4.41 & 3.66 & 4.34 & 3.87 \\
\hline Clean & 5.14 & 4.34 & 4.65 & 4.62 & 4.24 \\
\hline Courageous & 4.25 & 4.68 & 4.64 & 4.39 & 4.83 \\
\hline Forgiving & 4.75 & 4.82 & 4.55 & 4.57 & 5.12 \\
\hline Helpful & 4.77 & 4.76 & 4.73 & 4.39 & 4.12 \\
\hline Honest & 4.27 & 4.60 & 4.19 & 3.40 & 3.03 \\
\hline Imaginative & 4.52 & 5.09 & 4.69 & 4.81 & 4.92 \\
\hline Independent & 5.33 & 4.80 & 4.38 & 4.40 & 5.19 \\
\hline Intellectual & 5.14 & 4.66 & 5.25 & 4.91 & 4.68 \\
\hline Logical & 4.87 & 4.52 & 4.99 & 4.74 & 4.39 \\
\hline Loving & 4.93 & 4.85 & 5.06 & 4.53 & 5.37 \\
\hline Loyal & 4.78 & 4.01 & 4.60 & 4.54 & 4.80 \\
\hline Obedient & 4.78 & 4.45 & 3.81 & 4.03 & 3.76 \\
\hline Polite & 4.21 & 4.07 & 4.01 & 3.90 & 3.35 \\
\hline Responsible & 4.59 & 4.31 & 4.10 & 3.81 & 3.35 \\
\hline Self Controlled & 5.24 & 4.29 & 4.90 & 4.43 & 4.50 \\
\hline
\end{tabular}


A multivariate analysis of variance was performed, using Number of Years Teaching as the independent variable and the instrumental values of the RVS as the dependent variables. With 72 and 1862 degrees of freedom, the Wilks' lambda test $(F=1.2875)$ was not significant at the .05 level of confidence $(p=.058)$.

\section{Values by Age of Instructor}

Work values, terminal values, and instrumental values were examined by age of instructor (under $30,30-39,40-49,50$ \& over). The following factors were considered in the decision to use these categories of age: (1) to obtain a limited number of categories for the statistical analysis; (2) to somewhat balance the number of people in each category; (3) to use the same interval size (in so far as possible) for each category; and (4) to have categories that reflect life states which might be related to value changes (young adult; establishing careers, families, and status in the community; established in careers, changing family responsibilities with older children; and changing faimly constellations - adult children, etc.; approaching retirement).

\section{Work Values}

Scale means and standard deviations of the OWVI for various age groups are presented in Tables LXIII and LXIV. For the under 30 group, the means ranged from 19.56 (Solitude) to 28.13 (Task Satisfaction). The means for the 30-39 age group ranged from 18.71 (Solitude) to 31.43 (Task Satisfaction). For the 40-49 age group, the means ranged from 18.11 (Object Orientation) to 31.79 (Task Satisfaction). For the 50 and over group, the means ranged from 18.20 (Solitude) to 31.88 (Task Satisfaction). 
TABLE LXIII

SCALE MEANS ON THE OHIO WORK VALUES INVENTORY FOR THE LEVELS OF AGE

\begin{tabular}{lcccc}
\hline \multicolumn{1}{c}{ Value } & $\begin{array}{c}\text { Under 30 } \\
\text { (Group 1) }\end{array}$ & $\begin{array}{c}\text { 30-39 } \\
\text { (Group 2) }\end{array}$ & $\begin{array}{c}40-49 \\
\text { (Group 3) }\end{array}$ & $\begin{array}{c}50 \text { \& over } \\
\text { (Group 4) }\end{array}$ \\
\hline Altruism & 25.90 & 27.19 & 27.77 & 28.32 \\
Object Orientation & 21.33 & 19.52 & 18.11 & 19.32 \\
Security & 24.59 & 25.36 & 24.26 & 24.26 \\
Control & 23.39 & 21.26 & 20.33 & 20.42 \\
Self Realization & 27.87 & 30.47 & 31.04 & 31.38 \\
Independence & 25.59 & 27.44 & 27.28 & 27.43 \\
Money & 23.67 & 24.29 & 23.25 & 22.61 \\
Task Satisfaction & 28.13 & 31.43 & 31.79 & 31.88 \\
Solitude & 19.56 & 18.71 & 18.75 & 18.20 \\
Ideas/Data & 25.00 & 27.57 & 28.02 & 28.84 \\
Prestige & 22.18 & 18.96 & 18.77 & 18.67 \\
\hline
\end{tabular}


TABLE LXIV

SCALE STANDARD DEVIATIONS ON THE OHIO WORK VALUES INVENTORY

FOR THE LEVELS OF AGE

\begin{tabular}{lcccc}
\hline \multicolumn{1}{c}{ Value } & $\begin{array}{c}\text { Under 30 } \\
\text { (Group 1) }\end{array}$ & $\begin{array}{c}30-39 \\
\text { (Group 2) }\end{array}$ & $\begin{array}{c}40-49 \\
\text { (Group 3) }\end{array}$ & $\begin{array}{c}50 \text { \& Over } \\
\text { (Group 4) }\end{array}$ \\
\hline Altruism & 4.75 & 4.99 & 5.19 & 6.10 \\
Object Orientation & 6.18 & 6.64 & 6.71 & 7.26 \\
Security & 4.02 & 6.06 & 6.70 & 7.73 \\
Control & 4.93 & 6.45 & 6.55 & 6.55 \\
Self Realization & 4.73 & 3.99 & 3.83 & 3.50 \\
Independence & 3.04 & 4.59 & 4.50 & 5.33 \\
Money & 4.61 & 6.76 & 7.37 & 7.55 \\
Task Satisfaction & 5.63 & 4.24 & 3.90 & 3.86 \\
Solitude & 5.11 & 5.73 & 5.45 & 6.11 \\
Ideas/Data & 4.03 & 4.66 & 4.41 & 4.84 \\
Prestige & 5.75 & 6.21 & 6.30 & 6.63 \\
\hline
\end{tabular}

A multivariate analysis of variance was performed, using Age as the independent variable and work values as dependent variables. With 54 and 1382 degrees of freedom, the Wilks' lambda value $(F=2.5227)$ was significant at the .05 level of confidence $(p<.001)$. With the rejection of the statistical hypothesis for the multivariate analysis, univariate analyses of variance were performed on the dependent variables, using .05 level of confidence for each test. The statistical hypothesis that $\mu_{1}=\mu_{2}=\mu_{3}=\mu_{4}$ was rejected for six work values 
TABLE LXV

ANALYSIS OF VARIANCE TABLE FOR AGE USING WORK VALUES AS DEPENDENT VARIABLES

\begin{tabular}{lrrrrrrr}
\hline \multicolumn{1}{c}{ Variable } & Hy SS & Error SS & Hy MS & Error MS & F* & Sig. of F \\
\hline Altruism & 202.144 & 13504.724 & 67.381 & 28.135 & 2.395 & .068 \\
Object Orient. & 370.548 & 22028.411 & 123.516 & 45.893 & 2.691 & .046 \\
Security & 130.504 & 20562.149 & 43.501 & 42.838 & 1.015 & .386 \\
Control & 335.518 & 19642.737 & 111.839 & 40.922 & 2.733 & .043 \\
Self Realiz. & 387.679 & 7298.321 & 129.226 & 15.205 & 8.499 & .000 \\
Independence & 118.081 & 10342.636 & 39.360 & 21.547 & 1.827 & .141 \\
Money & 215.023 & 23489.066 & 71.674 & 48.936 & 1.465 & .223 \\
Task Satis. & 464.930 & 8406.632 & 154.977 & 17.514 & 8.849 & .000 \\
Solitude & 57.062 & 15557.359 & 19.021 & 32.411 & 0.587 & .624 \\
Ideas/Data & 442.638 & 100084.442 & 147.546 & 21.009 & 7.023 & .000 \\
Prestige & 410.717 & 19070.099 & 136.906 & 39.729 & 3.446 & .017 \\
\hline
\end{tabular}

$\star d f=3$ and 480

(See Table LXV). On each of these six variables, a Modified LSD was performed for each pair-wise mean comparison, using a .05 level of confidence. Group means and standard deviations were presented in Tables LXIII and LXIV. A summary of significant differences between group means is found in Table LXVI. As may be seen, instructors in Group 1 (ages 18 thru 29) placed less value on Self Realization, Task Satisfaction and Ideas/Data than any other age group; they placed more 
TABLE LXVI

SIGNIFICANT PAIR-WISE MEAN COMPARISONS BETWEEN LEVELS OF AGE ON THE OHIO WORK VALUES INVENTORY

\begin{tabular}{ll}
\hline \multicolumn{1}{c}{ OWVI Scales } & Pair-Wise Group Comparisons* \\
\hline Self Realization & $1-2,1-3,1-4$ \\
Task Satisfaction & $1-2,1-3,1-4$ \\
Ideas/Data & $1-2,1-3,1-4$ \\
Prestige & $1-2,1-3,1,4$ \\
\hline
\end{tabular}

*Age: Under $30(1) ; 30-39(2) ; 40-49(3)$; and 50 and over (4)

emphasis on Prestige than did any other age group. No significant pair-wise mean differences were found on Object Orientation and Control.

Rokeach Terminal Values

Each faculty member ranked the 18 Rokeach Terminal Scales. Scale means and standard deviations of the ranks are presented for various age groups in Tables LXVII and LXVIII. For the under 30 group, the means of the ranks ranged from a low of 11.80 (Salvation) to a high of 6.85 (Family Security). The means of the ranks for the 30-39 age group ranged from 13.27 (Social Recognition) to 5.78 (Health). The means of the ranks for the 40-49 age group ranged from 13.82 (National Security) to 5.26 (Health). For the 50 and over group, the means ranged from 13.48 (Social Recognition) to 5.37 (Self Respect). 
TABLE LXVII

SCALE MEANS ON THE ROKEACH TERMINAL VALUES SURVEY FOR THE LEVELS OF AGE

\begin{tabular}{|c|c|c|c|c|}
\hline RVS Scales & $\begin{array}{l}\text { Under } 30 \\
\text { (Group 1) }\end{array}$ & $\begin{array}{c}30-39 \\
\text { (Group 2) }\end{array}$ & $\begin{array}{c}40-49 \\
\text { (Group 3) }\end{array}$ & $\begin{array}{l}50 \text { \& Over } \\
\text { (Group 5) }\end{array}$ \\
\hline A Comfortable Life & 11.21 & 11.44 & 12.06 & 10.96 \\
\hline An Exciting Life & 10.33 & 11.01 & 10.88 & 10.17 \\
\hline A Sense of Accomplishment & 8.36 & 8.28 & 7.60 & 6.96 \\
\hline A World at Peace & 9.51 & 9.95 & 9.92 & 10.14 \\
\hline A World of Beauty & 9.23 & 11.59 & 11.23 & 11.38 \\
\hline Equality & 9.69 & 11.29 & 11.22 & 11.09 \\
\hline Family Security & 6.85 & 6.83 & 6.54 & 5.91 \\
\hline Freedom & 8.97 & 6.75 & 6.95 & 6.67 \\
\hline Health & 8.03 & 5.78 & 5.26 & 5.41 \\
\hline Inner Harmony & 7.80 & 6.86 & 7.22 & 7.82 \\
\hline Mature Love & 8.23 & 7.76 & 8.93 & 9.77 \\
\hline National Security & 10.67 & 13.27 & 13.82 & 13.00 \\
\hline Pleasure & 10.77 & 12.02 & 13.06 & 13.40 \\
\hline Salvation & 11.80 & 12.56 & 11.66 & 12.11 \\
\hline Self Respect & 7.46 & 6.13 & 5.35 & 5.37 \\
\hline Social Recognition & 11.46 & 13.37 & 13.13 & 13.48 \\
\hline True Friendship & 9.64 & 8.61 & 8.67 & 9.77 \\
\hline Wisdom & 11.05 & 7.53 & 7.48 & 7.52 \\
\hline
\end{tabular}


TABLE LXVIII

SCALE STANDARD DEVIATIONS ON THE ROKEACH TERMINAL VALUES SURVEY FOR THE LEVELS OF AGE

\begin{tabular}{|c|c|c|c|c|}
\hline RVS Scales & $\begin{array}{l}\text { Under } 30 \\
\text { (Group 1) }\end{array}$ & $\begin{array}{c}30-39 \\
\text { (Group 2) }\end{array}$ & $\begin{array}{c}40-49 \\
\text { (Group 3) }\end{array}$ & $\begin{array}{l}50 \text { \& Over } \\
\text { (Group 4) }\end{array}$ \\
\hline A Comfortable Life & 4.96 & 4.78 & 4.28 & 4.54 \\
\hline An Exciting Life & 4.56 & 4.52 & 4.39 & 5.25 \\
\hline A Sense of Accomplishment & 4.84 & 4.46 & 4.65 & 4.43 \\
\hline A World at Peace & 4.55 & 5.26 & 5.16 & 5.05 \\
\hline A World of Beauty & 4.61 & 3.87 & 4.41 & 4.30 \\
\hline Equality & 5.35 & 4.34 & 4.19 & 4.71 \\
\hline Family Security & 4.99 & 4.75 & 4.69 & 4.07 \\
\hline Freedom & 4.39 & 4.16 & 3.78 & 4.17 \\
\hline Health & 5.48 & 3.71 & 3.69 & 3.49 \\
\hline Inner Harmony & 4.67 & 4.41 & 4.67 & 4.12 \\
\hline Mature Love & 5.37 & 4.17 & 4.42 & 4.65 \\
\hline National Security & 4.80 & 4.80 & 4.05 & 4.25 \\
\hline Pleasure & 5.55 & 4.12 & 3.85 & 3.80 \\
\hline Salvation & 5.13 & 6.73 & 6.90 & 6.96 \\
\hline Self Respect & 5.09 & 3.91 & 3.77 & 3.86 \\
\hline Social Recognition & 4.86 & 3.91 & 3.72 & 3.42 \\
\hline True Friendship & 5.31 & 4.15 & 4.08 & 3.90 \\
\hline Wisdom & 5.80 & 4.85 & 4.65 & 4.26 \\
\hline
\end{tabular}


A multivariate analysis of variance was performed using Age as the independent variable and terminal values of the RVS as dependent variables. With 54 and 1382 degrees of freedom, the Wilks' lambda value $(F=2.5227)$ was significant at the .05 level of confidence $(p<.001)$. With the rejection of the statistical hypothesis for the multivariate analysis, univariate analyses of variance were performed on the independent variable, using a .05 level of confidence for each test. The statistical hypothesis that $\mu_{1}=\mu_{2}=\mu_{3}=\mu_{4}$ was rejected for nine terminal values (See Table LXIX). On each of these nine variables a Modified LSD was performed for each pair-wise mean comparison using a .05 level of confidence. Group means and standard deviations were presented in Tables LXVII and LXVIII. A summary of significant differences between group means is found in Table LXX. As may be seen, instructors in Group 1 (age 18 thru 29) placed more value on A World of Beauty than did Groups 2 (age 30-39) and 4 (age 50 and over). Groups 2, 3 (age 40-49) and 4 placed greater value on Freedom than did Group 1. Groups 2, 3 and 4 placed greater value on Health than did Group 1. Group 2 placed greater value on Mature Love than did Group 4. National Security had greater value placed on it by Group 1 than any other group. Pleasure was valued more by Group 1 than by Groups 3 and 4; but Group 2 also placed more value on it than did Group 4. Groups 3 and 4 placed greater value on Self Respect than did Group 1. Social Recognition was accorded more value by Group 1 than by Groups 2 and 4 . Finally, Wisdom had greater value placed on it by Groups 2, 3 and 4 than by Group 1 (Under 30). 
TABLE LXIX

ANALYSIS OF VARIANCE TABLE FOR AGE USING TERMINAL VALUES AS DEPENDENT VARIABLES

\begin{tabular}{lrrrrrrr}
\hline \multicolumn{1}{c}{ Variable } & Hy SS & Error SS & Hy MS & Error MS & F* & Sig. of F \\
\hline A Comfort. Life & 82.616 & 10120.122 & 27.539 & 21.128 & 1.303 & .273 \\
An Excit. Life & 58.422 & 10410.402 & 19.474 & 21.734 & 0.896 & .443 \\
A Sense of Acc. & 138.134 & 9877.162 & 46.045 & 20.620 & 2.233 & .084 \\
A World at Peace & 11.799 & 12587.009 & 3.933 & 26.278 & 0.150 & .930 \\
A World of Beau. & 182.380 & 8434.278 & 60.793 & 17.608 & 3.453 & .016 \\
Equality & 86.329 & 9577.290 & 28.776 & 19.994 & 1.439 & .231 \\
Family Security & 63.074 & 10167.241 & 21.025 & 21.226 & 0.991 & .397 \\
Freedom & 175.981 & 9733.613 & 58.660 & 15.563 & 3.542 & .015 \\
Health & 249.015 & 7009.809 & 83.005 & 14.634 & 5.672 & .001 \\
Inner Harmony & 76.102 & 9473.505 & 25.367 & 19.778 & 1.283 & .280 \\
Mature Love & 306.316 & 9542.943 & 102.105 & 19.923 & 5.125 & .002 \\
National Sec. & 309.980 & 9624.745 & 103.327 & 20.093 & 5.142 & .002 \\
Pleasure & 292.840 & 8058.953 & 97.613 & 16.825 & 5.802 & .001 \\
Salvation & 71.358 & 21633.938 & 23.786 & 45.165 & 0.527 & .664 \\
Self Respect & 177.598 & 7535.139 & 59.199 & 15.731 & 3.763 & .011 \\
Social Recog. & 132.055 & 7028.682 & 44.018 & 14.674 & 3.000 & .030 \\
True Friend. & 125.179 & 8363.570 & 41.726 & 17.460 & 2.390 & .068 \\
Wisdom & 449.497 & 10786.619 & 149.832 & 22.519 & 6.654 & .000 \\
\hline & & & & & & & \\
\hline
\end{tabular}

*df $=3$ and 479 
TABLE LXX

SIGNIFICANT PAIR-WISE MEAN COMPARISONS FOR THE LEVELS OF AGE

ON THE ROKEACH TERMINAL VALUES

\begin{tabular}{ll} 
RVS Terminal Values & Pair-Wise Group Comparisons* \\
\hline A World of Beauty & $1-2,1-4$ \\
Freedom & $1-2,1-3,1-4$ \\
Health & $1-2,1-3,1-4$ \\
Mature Love & $2-4$ \\
National Security & $1-2,1-3,1-4$ \\
Pleasure & $1-3,1-4,2-4$ \\
Self Respect & $1-3,1-4$ \\
Social Recognition & $1-2,1-4$ \\
Wisdom & $1-21-3,1-4$ \\
\hline
\end{tabular}

*Age: Under $30(1) ; 30-39$ (2); 40-49 (3); and 50 and over (4)

Rokeach Instrumental Values

Scale means and standard deviations of the ranks of the Rokeach Instrumental Values are presented, for various age groups, in Tables LXXI and LXXII. For the under 30 age group, the means of the ranks ranged from 12.39 (Obedient) to 6.64 (Responsible). For the 30-39 age group, the means ranged from 15.34 (Obedient) to 5.10 (Honest). The means of the ranks for the 40-49 age group ranged from 15.01 (Obedient) to 4.26 (Honest). For the 50 and over age group, the means ranged from 15.42 (Obedient) to 4.08 (Honest). 
TABLE LXXI

SCALE MEANS ON THE ROKEACH INSTRUMENTAL VALUES SURVEY FOR THE LEVELS OF AGE

\begin{tabular}{|c|c|c|c|c|}
\hline RVS Scales & $\begin{array}{l}\text { Under } 30 \\
\text { (Group 1) }\end{array}$ & $\begin{array}{c}30-39 \\
\text { (Group 2) }\end{array}$ & $\begin{array}{c}40-49 \\
\text { (Group 3) }\end{array}$ & $\begin{array}{l}50 \text { \& Over } \\
\text { (Group } 4 \text { ) }\end{array}$ \\
\hline Ambitious & 9.41 & 10.67 & 10.37 & 10.24 \\
\hline Broadminded & 8.49 & 9.04 & 9.17 & 9.23 \\
\hline Capable & 8.72 & 7.48 & 6.99 & 7.76 \\
\hline Clean & 11.33 & 13.42 & 13.65 & 13.02 \\
\hline Courageous & 7.82 & 9.28 & 9.12 & 9.06 \\
\hline Forgiving & 8.44 & 9.57 & 8.94 & 10.36 \\
\hline Helpful & 8.64 & 8.89 & 7.97 & 8.71 \\
\hline Honest & 7.95 & 5.10 & 4.26 & 4.08 \\
\hline Imaginative & 10.31 & 10.11 & 10.95 & 9.60 \\
\hline Independent & 9.23 & 8.07 & 8.22 & 7.35 \\
\hline Intellectual & 9.18 & 8.21 & 8.85 & 8.75 \\
\hline Logical & 10.36 & 10.11 & 10.10 & 9.89 \\
\hline Loving & 8.39 & 6.95 & 7.42 & 8.96 \\
\hline Loya & 8.56 & 9.67 & 9.59 & 9.56 \\
\hline Obedient & 12.39 & 15.34 & 15.01 & 15.42 \\
\hline Polite & 10.82 & 12.60 & 12.63 & 13.16 \\
\hline Responsible & 6.64 & 6.30 & 6.26 & 5.66 \\
\hline Self Controlled & 11.90 & 11.50 & 11.45 & 10.33 \\
\hline
\end{tabular}


TABLE LXXII

SCALE STANDARD DEVIATIONS ON THE ROKEACH INSTRUMENTAL VALUES SURVEY FOR THE LEVELS OF AGE

\begin{tabular}{|c|c|c|c|c|}
\hline RVS Scales & $\begin{array}{l}\text { Under } 30 \\
\text { (Group 1) }\end{array}$ & $\begin{array}{c}30-39 \\
\text { (Group 2) }\end{array}$ & $\begin{array}{c}40-49 \\
\text { (Group 3) }\end{array}$ & $\begin{array}{l}50 \text { \& Over } \\
\text { (Group 4) }\end{array}$ \\
\hline Ambitious & 5.54 & 4.48 & 5.42 & 5.63 \\
\hline Broadminded & 4.98 & 4.83 & 4.58 & 4.76 \\
\hline Capable & 4.86 & 4.14 & 3.91 & 4.36 \\
\hline Clean & 4.60 & 4.45 & 4.47 & 5.09 \\
\hline Courageous & 4.12 & 4.48 & 4.56 & 4.99 \\
\hline Forgiving & 5.19 & 4.67 & 4.63 & 4.82 \\
\hline Helpful & 5.25 & 4.52 & 4.75 & 4.17 \\
\hline Honest & 5.33 & 4.11 & 3.72 & 3.33 \\
\hline Imaginative & 4.37 & 4.97 & 4.88 & 4.54 \\
\hline Independent & 4.02 & 4.61 & 4.70 & 4.89 \\
\hline Intel lectual & 5.16 & 4.89 & 4.80 & 5.15 \\
\hline Logical & 4.96 & 4.09 & 4.48 & 4.63 \\
\hline Loving & 5.95 & 5.96 & 4.82 & 4.95 \\
\hline Loyal & 5.25 & 5.43 & 4.59 & 4.42 \\
\hline Obedient & 5.52 & 4.01 & 4.28 & 3.83 \\
\hline Polite & 4.76 & 3.95 & 3.81 & 3.68 \\
\hline Responsible & 5.16 & 3.97 & 4.11 & 3.67 \\
\hline Self Controlled & 4.25 & 4.89 & 4.74 & 4.18 \\
\hline
\end{tabular}


A multivariate analysis of variance was performed, using Age as the independent variable and Instrumental values as dependent variables. With 54 and 1379 degrees of freedom, the Wilks' lambda value $(F=2.210)$ was significant at the .05 ievel of confidence $(p<.001)$. With the rejection of the statistical hypothesis for the multivariate analysis, univariate analyses of variance were performed on the dependent variables using the .05 level of confidence for each test. The statistical hypothesis that $\mu_{1}=\mu_{2}=\mu_{3}=\mu_{4}$ was rejected for six instrumental values (See Table LXXIII). On each of these six variables, a Modified LSD was performed for each pair-wise mean comparison using a .05 level of confidence. Group means and standard deviations were presented in Tables LXXI and LXXII. A summary of significant differences between group means are found in Table LXXIV. As may be seen, Group 1 (under 30) placed greater value on Clean than did Group 3 (age 40-49). Groups $2(30-39), 3$ and 4 (50 and over) placed greater value on Honest than did Group 1. The youngest group (Group 1) placed more value on Obedient than did the older groups (Groups 2, 3 and 4). Group 1 placed more value on Polite than did Group 4. The younger group (Group 1) placed less value on Responsible than did the older groups (Groups 2, 3, and 4). 
TABLE LXXIII

ANALYSIS OF VARIANCE TABLE FOR AGE USING INSTRUMENTAL VALUES AS DEPENDENT VARIABLES

\begin{tabular}{|c|c|c|c|c|c|c|}
\hline Variable & Hy SS & Error SS & Hy MS & Error MS & $F^{\star}$ & Sig. of $F$ \\
\hline Ambitious & 55.664 & 13244.095 & 18.555 & 27.707 & 0.670 & .571 \\
\hline Broadminded & 17.261 & 10797.383 & 5.874 & 22.589 & 0.260 & .854 \\
\hline Capable & 103.625 & 8364.867 & 34.542 & 17.500 & 1.974 & .117 \\
\hline Clean & 177.191 & 10203.705 & 59.604 & 21.347 & 2.767 & .041 \\
\hline Courageous & 69.586 & 10102.547 & 23.195 & 21.135 & 1.097 & .350 \\
\hline Forgiving & 169.292 & 10712.741 & 56.431 & 22.412 & 2.518 & .057 \\
\hline Helpful & 74.045 & 10001.158 & 24.682 & 20.923 & 1.180 & .317 \\
\hline Honest & 500.220 & 7424.419 & 166.740 & 15.553 & 10.721 & .000 \\
\hline Imaginative & 121.028 & 11022.034 & 40.343 & 23.059 & 1.750 & .156 \\
\hline Independent & 112.942 & 11128.228 & 37.647 & 23.281 & 1.617 & .185 \\
\hline Intellectual & 54.012 & 11683.506 & 18.004 & 24.442 & 0.737 & .531 \\
\hline Logical & 7.235 & 18443.769 & 2.412 & 38.585 & 0.053 & .980 \\
\hline Loving & 310.565 & 19260.657 & 103.522 & 40.294 & 2.569 & .054 \\
\hline Loyal & 40.783 & 16563.250 & 13.594 & 34.651 & 0.392 & .759 \\
\hline Obedient & 308.160 & 8401.633 & 102.720 & 17.577 & 5.844 & .001 \\
\hline Polite & 157.358 & 7341.305 & 52.453 & 15.358 & 3.415 & .017 \\
\hline Responsible & 473.702 & 7853.311 & 157.901 & 16.430 & 9.611 & .000 \\
\hline Self Control. & 127.408 & 10310.716 & 42.469 & 21.571 & 1.969 & .018 \\
\hline
\end{tabular}


TABLE LXXIV

SIGNIFICANT PAIR-WISE MEAN COMPARISONS BETWEEN LEVELS OF AGE ON THE ROKEACH INSTRUMENTAL VALUES

RVS Instrumental Scales

Pair-wise Group Comparisons*

Clean

$1-3$

Honest

$1-2 \quad 1-3,1-4$

Obedient

$1-2,1-3,1-4$

Polite

$1-4$

Responsible

$1-2,1-3,1-4$

*Age: Under 30 (1); 30-39 (2); 40-49 (3); and 50 and over (4)

Values by Degrees Held

Work values, terminal values, and instrumental values were examined by highest degree held: Doctorate (Group 1); Master's (Group 2); Bachelor's (Group 3); Associate (Group 4); and 0ther (Group 5).

Work Values

OWVI Scale means and standard deviations for categories of degrees heid are presented in Tables LXXV and LXXVI. For those with Doctorates, the means ranged from 18.50 (Prestige) to 32.26 (Task Satisfaction). For the Master's degree group, the means ranged from 18.30 (Solitude) to 31.44 (Task Satisfaction). For the Bachelor's degree group, the means ranged from 19.06 (Solitude) to 31.24 (Task Satisfaction). The means ranged from 18.84 (Solitude) to 30.40 (Self Realization) for the 
TABLE LXXV

SCALE MEANS ON THE OHIO WORK VALUES INVENTORY FOR LEVELS OF HIGHEST DEGREE HELD

\begin{tabular}{lccccc}
\hline \multicolumn{1}{c}{ OwVI Value } & $\begin{array}{r}\text { Doctorate } \\
\text { (Group 1) }\end{array}$ & $\begin{array}{c}\text { Master's } \\
\text { (Group 2) }\end{array}$ & $\begin{array}{r}\text { Bachelor's } \\
\text { (Group 3) }\end{array}$ & $\begin{array}{c}\text { Associate } \\
\text { (Group 4) }\end{array}$ & $\begin{array}{c}\text { Other } \\
\text { (Group 5) }\end{array}$ \\
\hline Altruism & 26.90 & 27.42 & 28.13 & 25.50 & 24.33 \\
Object Orientation & 18.55 & 18.36 & 19.87 & 23.79 & 24.00 \\
Security & 24.47 & 24.72 & 24.66 & 26.29 & 19.00 \\
Control & 18.95 & 20.40 & 22.71 & 24.26 & 20.17 \\
Self Realization & 31.13 & 30.64 & 30.74 & 30.40 & 28.17 \\
Independence & 29.84 & 26.95 & 27.45 & 26.29 & 28.67 \\
Money & 24.03 & 22.89 & 25.21 & 25.32 & 22.33 \\
Task Satisfaction & 32.26 & 31.44 & 31.24 & 29.95 & 31.00 \\
Solitude & 19.55 & 18.30 & 19.06 & 18.84 & 26.33 \\
Ideas/Data & 29.87 & 27.80 & 27.07 & 26.97 & 29.17 \\
Prestige & 18.50 & 18.77 & 19.45 & 21.53 & 18.33 \\
\hline
\end{tabular}


TABLE LXXVI

SCALE STANDARD DEVIATIONS ON THE OHIO WORK VALUES INVENTORY FOR LEVELS OF HIGHEST DEGREE HELD

\begin{tabular}{lccccc}
\hline \multicolumn{1}{c}{ OWVI Scale } & $\begin{array}{r}\text { Doctorate } \\
\text { (Group 1) }\end{array}$ & $\begin{array}{r}\text { Master's } \\
\text { (Group 2) }\end{array}$ & $\begin{array}{r}\text { Bachelor's } \\
\text { (Group 3) }\end{array}$ & $\begin{array}{c}\text { Associate } \\
\text { (Group 4) }\end{array}$ & $\begin{array}{c}\text { Other } \\
\text { (Group 5) }\end{array}$ \\
\hline Altruism & 6.00 & 5.34 & 4.93 & 5.14 & 6.19 \\
Object Orient. & 6.65 & 6.57 & 7.18 & 6.23 & 7.24 \\
Security & 7.72 & 6.42 & 6.36 & 5.77 & 7.04 \\
Control & 6.31 & 6.47 & 6.12 & 5.64 & 7.14 \\
Self Realization & 4.13 & 3.98 & 3.53 & 4.75 & 4.26 \\
Independence & 4.72 & 4.69 & 4.30 & 4.67 & 3.50 \\
Money & 8.27 & 7.11 & 6.16 & 5.64 & 8.60 \\
Task Satisfaction & 3.67 & 4.19 & 4.01 & 4.07 & 3.03 \\
Solitude & 5.64 & 5.56 & 5.88 & 5.43 & 4.55 \\
Ideas/Data & 3.46 & 4.85 & 4.26 & 4.80 & 4.40 \\
Prestige & 7.25 & 6.38 & 5.69 & 6.51 & 6.35 \\
\hline
\end{tabular}

Associate degree groups. For the nondegree group, the means ranged from 18.33 (Prestige) to 31.00 (Task Satisfaction).

A multivariate analysis of variance was performed, using Highest Degree Held as the independent variable and work values as dependent variables. With 44 and 1898 degrees of freedom, the Wilks' lambda value $(F=2.5174)$ was significant at the .05 level of confidence $(p<.001)$. The statistical hypothesis was rejected. With the rejection of the statistical hypothesis for the multivariate analysis, univariate analyses of variance were performed on the dependent variables, using a 
.05 level of confidence for each test. The statistical hypothesis that $\mu_{1}=\mu_{2}=. . .=\mu_{5}$ was rejected for six work values (See Table LXXVII). These values are Object Orientation, Control, Independence, Money, Solitude, and Ideas/Data.

On each of these six variables, a Modified LSD was performed for each pair-wise mean comparison, using a .05 level of confidence. Group means and standard deviations were presented in Tables LXXV and LXXVI. A summary of significant differences between group means is found in Table LXXVIII. As may be seen, instructors with Associate Degrees placed greater value on Object Orientation than did instructors with Doctorates, Master's, and Bachelor's degrees. Instructors with Associate and Bachelor's degrees placed greater value on Control than did instructors with Doctor's and Master's degrees. Instructors with Doctor's degrees placed greater value on Independence than did those who held Master's and Associate degrees. Those instructors with Other (no degree, generally) placed greater value on Solitude than did instructors with Master's, Bachelor's, and Associate degrees. Finally, those instructors with Doctorates placed greater value on Ideas/Data than did instructors who held Bachelor's degrees. 
TABLE LXXVII

ANALYSIS OF VARIANCE TABLE FOR HIGHEST DEGREE HELD USING WORK VALUES AS DEPENDENT VARIABLES

\begin{tabular}{lrrrrrrr}
\hline \multicolumn{1}{c}{ Variable } & Hy SS & Error SS & Hy MS & Error MS & $F^{*}$ & Sig. of F \\
\hline Altruism & 108.656 & 13753.539 & 27.164 & 28.299 & 0.960 & .429 \\
Object Orient. & 1219.241 & 21588.373 & 304.810 & 44.421 & 6.862 & .000 \\
Security & 292.352 & 20378.279 & 73.088 & 41.931 & 1.743 & .139 \\
Control & 926.088 & 19589.390 & 231.522 & 40.307 & 5.744 & .000 \\
Self Realization & 49.057 & 7719.571 & 12.264 & 15.884 & 0.772 & .544 \\
Independence & 334.728 & 10367.724 & 83.682 & 21.333 & 3.923 & .004 \\
Money & 505.002 & 23628.807 & 126.250 & 48.619 & 2.597 & .036 \\
Task Satis. & 110.775 & 8938.972 & 27.694 & 18.393 & 1.506 & .199 \\
Solitude & 439.719 & 15243.503 & 109.930 & 31.365 & 3.505 & .008 \\
Idea/Data & 242.989 & 10534.982 & 60.747 & 21.677 & 2.802 & .025 \\
Prestige & 286.095 & 19622.410 & 71.524 & 40.375 & 1.771 & .133 \\
\hline
\end{tabular}

$\star d f=4$ and 486 
TABLE LXXVIII

SIGNIFICANT PAIR-WISE MEAN COMPARISONS BETWEEN LEVELS OF HIGHEST DEGREE HELD ON THE OHIO WORK VALUES INVENTORY

\begin{tabular}{ll}
\hline \multicolumn{1}{c}{ OWVI Scales } & Pair-wise Group Comparisons* \\
\hline Object Orientation & $4-1,4-2,4-3$ \\
Control & $4-1,4-2,3-1,3-2$ \\
Independence & $1-2,1-4$ \\
Solitude & $5-2,5-3,5-4$ \\
Ideas/Data & $1-3$ \\
\hline
\end{tabular}

*Degree: Doctorate (1); Master's (2); Bachelor's (3); Associate (4); other (5)

Rokeach Terminal Values

Each faculty member ranked the Rokeach Terminal Values. Scale means and standard deviations of the values are presented for categories of degrees held in Tables LXXIX and LXXX. For instructors with Doctorates, the mean ranks ranged from 15.18 (National Security) to 4.84 (Self Respect). For the Masters' degree groups the mean ranks ranged from 13.28 (National Security) to 5.77 (Self Respect). The mean ranks, for the Bachelor's degree group, ranged from 13.23 (Social Recognition) to 5.42 (Family Security). For the Associate degree group, the means ranged from 12.66 (Social Recognition) to 5.00 (Health). For the 0ther group, the mean ranks ranged from 15.83 (Salvation) to 3.33 (Health). 
TABLE LXXIX

SCALE MEANS ON THE ROKEACH TERMINAL VALUES SURVEY FOR THE LEVELS OF HIGHEST DEGREE HELD

\begin{tabular}{lccccc}
\hline RVS Scales & $\begin{array}{c}\text { Doctorate } \\
\text { (Group 1) }\end{array}$ & $\begin{array}{c}\text { Master's } \\
\text { (Group 2) }\end{array}$ & $\begin{array}{c}\text { Bachelor's } \\
\text { (Group 3) }\end{array}$ & $\begin{array}{c}\text { Associate } \\
\text { (Group 4) }\end{array}$ & $\begin{array}{c}\text { Other } \\
\text { (Group 5) }\end{array}$ \\
\hline A Comfort. Life & 11.76 & 11.77 & 10.55 & 9.84 & 14.33 \\
An Excit. Life & 9.11 & 10.83 & 11.34 & 10.61 & 8.50 \\
A Sense of Acc. & 8.50 & 7.64 & 7.90 & 8.11 & 5.67 \\
A World at Peace & 10.63 & 9.85 & 10.04 & 10.40 & 13.50 \\
A World of Beau. & 11.40 & 11.04 & 11.90 & 12.03 & 9.33 \\
Equality & 10.84 & 11.09 & 11.67 & 10.42 & 12.00 \\
Family Security & 7.61 & 6.67 & 5.42 & 6.53 & 8.67 \\
Freedom & 6.47 & 6.60 & 7.78 & 8.66 & 8.33 \\
Health & 5.79 & 5.90 & 5.48 & 5.00 & 3.33 \\
Inner Harmony & 7.45 & 6.99 & 7.76 & 8.08 & 6.17 \\
Mature Love & 7.26 & 8.79 & 8.34 & 8.97 & 6.00 \\
Nat. Security & 15.18 & 13.28 & 12.34 & 11.82 & 14.17 \\
Pleasure & 12.63 & 12.51 & 12.52 & 12.32 & 12.17 \\
Salvation & 14.76 & 11.97 & 11.67 & 11.50 & 15.83 \\
Self Respect & 4.84 & 5.77 & 5.94 & 7.00 & 5.00 \\
Social Recog. & 13.87 & 13.12 & 13.23 & 12.66 & 13.17 \\
True Friend. & 7.16 & 9.27 & 9.44 & 9.42 & 8.67 \\
Wisdom & 5.71 & 7.87 & 8.70 & 7.63 & 6.17 \\
\hline & & & & & \\
\hline
\end{tabular}


TABLE LXXX

SCALE STANDARD DEVIATIONS ON THE ROKEACH TERMINAL VALUES SURVEY FOR THE LEVELS OF HIGHEST DEGREE HELD

\begin{tabular}{|c|c|c|c|c|c|}
\hline RVS Scales & $\begin{array}{l}\text { Doctorate } \\
\text { (Group 1) }\end{array}$ & $\begin{array}{l}\text { Master's } \\
\text { (Group 2) }\end{array}$ & $\begin{array}{l}\text { Bachelor's } \\
\text { (Group 3) }\end{array}$ & $\begin{array}{l}\text { Associate } \\
\text { (Group } 4 \text { ) }\end{array}$ & $\begin{array}{c}\text { Other } \\
\text { (Group 5) }\end{array}$ \\
\hline A Comfortable Life & 5.33 & 4.31 & 4.95 & 5.32 & 2.42 \\
\hline An Exciting Life & 4.38 & 4.57 & 4.70 & 4.65 & 6.32 \\
\hline A Sense of Accomp. & 3.88 & 4.47 & 5.10 & 4.31 & 4.84 \\
\hline A World of Peace & 5.17 & 5.18 & 5.13 & 4.58 & 3.08 \\
\hline A World of Beauty & 4.02 & 4.28 & 4.00 & 4.38 & 4.13 \\
\hline Equality & 4.54 & 4.37 & 4.51 & 5.27 & 3.80 \\
\hline Family Security & 4.79 & 4.65 & 4.11 & 4.67 & 3.93 \\
\hline Freedom & 3.80 & 3.91 & 4.37 & 4.78 & 4.80 \\
\hline Hea lth & 3.47 & 3.91 & 4.09 & 4.20 & 2.50 \\
\hline Inner Harmony & 4.81 & 4.45 & 4.34 & 4.82 & 2.48 \\
\hline Mature Love & 4.37 & 4.52 & 4.59 & 4.52 & 4.00 \\
\hline National Security & 2.95 & 4.65 & 4.25 & 4.72 & 3.82 \\
\hline Pleasure & 3.22 & 4.31 & 4.38 & 3.77 & 3.06 \\
\hline Salvation & 5.24 & 6.85 & 6.64 & 6.67 & 3.71 \\
\hline Self Respect & 3.03 & 3.90 & 4.24 & 4.51 & 5.33 \\
\hline Social Recognition & 3.52 & 3.75 & 4.03 & 4.74 & 5.12 \\
\hline True Friendship & 4.00 & 4.18 & 4.20 & 4.30 & 2.88 \\
\hline Wisdom & 3.78 & 4.98 & 4.42 & 5.25 & 4.07 \\
\hline
\end{tabular}


A multivariate analysis of variance was performed, using Highest Degree Held as the independent variable and the Terminal values of Rokeach as dependent variables. With 72 and 1866 degrees of freedom, the Wilks' lambda value $(F=1.5287)$ was significant at the .05 level of confidence $(p=.003)$. The statistical hypothesis was rejected for the multivariate analysis. With the rejection of the multivariate statistical hypothesis, univariate analyses of variance were performed on the dependent variables, using a .05 level of confidence for each test. The statistical hypothesis that $\mu_{1}=\mu_{2}=. .=\mu_{5}$ was rejected for five terminal values: A Comfortable Life, Freedom, National Security, True Friendship, and Wisdom. (See Table LXXXI).

On each of these five variables, a Modified LSD was performed for each pair-wise mean comparison, using a .05 level of confidence. Group means and standard deviations were presented in Tables LXXIX and LXXX. As may be seen, instructors with Master's degrees placed greater value on Freedom than did instructors with Associate degrees. Instructors with Bachelor's and Associate degrees placed greater value on National Security than did instructors with Doctor's degrees. Instructors with Doctorates placed greater value on True friendship than did instructors with Master's, while instructors with Doctorates placed greater value on Wisdom than did instructors with Bachelor's degrees. No significant pair-wise mean comparison was found on A Comfortable Life. (See Table LXXXII.) 
TABLE LXXXI

ANALYSIS OF VARIANCE TABLE FOR HIGHEST DEGREE HELD USING TERMINAL VALUES AS DEPENDEN'T VARIABLE

\begin{tabular}{lrrrrrrr}
\hline Variable & Hy SS & Error SS & Hy MS & Error MS & F* Sig. of F \\
\hline A Comfort. Life & 251.816 & 10159.305 & 62.954 & 20.947 & 3.005 & .018 \\
An Exciting Life & 164.347 & 10283.631 & 41.087 & 21.203 & 1.938 & .103 \\
A Sense of Acc. & 58.391 & 9953.193 & 14.598 & 20.522 & 0.711 & .584 \\
A World at Peace & 102.013 & 12678.643 & 25.503 & 26.142 & 0.976 & .420 \\
A World of Beauty & 94.437 & 8648.004 & 23.609 & 17.831 & 1.324 & .260 \\
Equality & 51.309 & 9712.846 & 12.827 & 20.026 & 0.641 & .634 \\
Family Security & 179.503 & 10118.009 & 44.876 & 20.862 & 2.151 & .073 \\
Freedom & 228.450 & 8015.961 & 57.112 & 16.528 & 3.456 & .008 \\
Health & 69.737 & 7440.959 & 17.434 & 15.342 & 1.136 & .339 \\
Inner Harmony & 76.840 & 9718.101 & 19.210 & 20.037 & 0.959 & .430 \\
Mature Love & 130.956 & 9896.597 & 32.739 & 20.405 & 1.604 & .172 \\
National Security & 289.763 & 9711.847 & 72.441 & 20.024 & 3.518 & .006 \\
Pleasure & 2.688 & 8547.810 & 0.672 & 17.924 & 0.038 & .997 \\
Salvation & 386.772 & 21547.940 & 96.693 & 44.429 & 2.176 & .071 \\
Self Respect & 95.150 & 7628.950 & 23.787 & 15.730 & 1.512 & .197 \\
Social Recog. & 29.521 & 7291.418 & 7.380 & 15.034 & 0.491 & .742 \\
True Friendship & 185.510 & 8426.090 & 46.378 & 17.373 & 2.669 & .032 \\
Wisdom & 250.203 & 11282.198 & 62.551 & 23.262 & 2.689 & .031 \\
\hline & & & & & & \\
\hline
\end{tabular}

$\star d f=4$ and 485 
TABIE LXXXXI!

SIGNIFICANT PAIR-WISE MEAN COMPARISONS BETWEEN LEVELS OF HIGHEST DEGREE HELD ON THE ROKEACH TERMINAL VALUES

RVS Terminal Values

Pair-wise Group Comparisons*

\begin{tabular}{ll}
\hline Freedom & $2-4$ \\
National Security & $1-3,1-4$ \\
True Friendship & $1-2$ \\
Wisdom & $1-3$ \\
\hline
\end{tabular}

*Degree: Doctorate (1); Master's (2); Bachelor's (3); Associate (4); other (5)

Rokeach Instrumental Values

Scale means and standard deviations of the ranks of the Rokeach Instrumental Values are presented in Tables LXXXIII and LXXXIV for categories of highest degree held. For those with Doctorates, the mean ranks ranged from 15.90 (Obedient) to 4.24 (Honest). For those with Master's degrees, the mean ranks ranged from 15.21 (Obedient) to 4.87 (Honest). For those with Bachelor's degrees, the mean ranks ranged from 14.77 (Obedient) to 5.22 (Honest). For the Associate degree group, the mean ranks ranged from 13.53 (Obedient) to 4.47 (Honest). For the Other category, the mean ranks ranged from 15.18 (Obedient) to 5.50 (Independent). 
TABLE LXXXIII

SCALE MEANS ON THE ROKEACH INSTRUMENTAL VALUES SURVEY

FOR THE LEVELS OF HIGHEST DEGREE HELD

\begin{tabular}{|c|c|c|c|c|c|}
\hline RVS Scales & $\begin{array}{l}\text { Doctorate } \\
\text { (Group 1) }\end{array}$ & $\begin{array}{l}\text { Master's } \\
\text { (Group 2) }\end{array}$ & $\begin{array}{r}\text { Bachelor's } \\
\text { (Group 3) }\end{array}$ & $\begin{array}{l}\text { Associate } \\
\text { (Group 4) }\end{array}$ & $\begin{array}{c}\text { Other } \\
\text { (Group 5) }\end{array}$ \\
\hline Ambitious & 10.86 & 10.67 & 9.77 & 9.16 & 10.67 \\
\hline Broadminded & 8.13 & 9.04 & 9.12 & 9.61 & 11.50 \\
\hline Capable & 8.40 & 7.33 & 7.76 & 7.18 & 6.67 \\
\hline Clean & 14.50 & 13.54 & 12.40 & 10.37 & 12.50 \\
\hline Courageous & 7.71 & 9.12 & 9.48 & 9.95 & 9.17 \\
\hline Forgiving & 9.74 & 9.67 & 9.10 & 8.61 & 11.33 \\
\hline Helpful & 8.92 & 8.36 & 8.95 & 9.95 & 11.50 \\
\hline Honest & 4.24 & 4.87 & 5.22 & 4.47 & 6.67 \\
\hline Imaginative & 8.61 & 10.37 & 10.63 & 10.00 & 9.67 \\
\hline Independent & 8.47 & 7.77 & 8.02 & 9.24 & 5.50 \\
\hline Intellectual & 6.03 & 8.19 & 10.32 & 10.21 & 9.17 \\
\hline Logical & 9.47 & 9.75 & 10.21 & 10.53 & 10.50 \\
\hline Loving & 7.00 & 7.42 & 8.49 & 8.21 & 6.33 \\
\hline Loyal & 10.24 & 9.42 & 9.38 & 10.08 & 9.50 \\
\hline Obedient & 15.90 & 15.21 & 14.77 & 13.53 & 15.18 \\
\hline Polite & 13.24 & 12.63 & 12.37 & 12.37 & 9.50 \\
\hline Responsible & 7.23 & 6.27 & 6.65 & 6.42 & 5.83 \\
\hline Self Controlled & 12.03 & 11.33 & 10.51 & 11.45 & 9.83 \\
\hline
\end{tabular}


TABLE LXXXIV

SCALE STANDARD DEVIATIONS ON THE ROKEACH INSTRUMENTAL VALUES SURVEY FOR THE LEVELS OF HIGHEST DEGREE HELD

\begin{tabular}{|c|c|c|c|c|c|}
\hline RVS Scales & $\begin{array}{l}\text { Doctorate } \\
\text { (Group 1) }\end{array}$ & $\begin{array}{l}\text { Master's } \\
\text { (Group 2) }\end{array}$ & $\begin{array}{l}\text { Bachelor's } \\
\text { (Group 3) }\end{array}$ & $\begin{array}{l}\text { Associate } \\
\text { (Group 4) }\end{array}$ & $\begin{array}{l}\text { Other } \\
\text { (Group 5) }\end{array}$ \\
\hline Ambitious & 5.80 & 5.08 & 5.59 & 4.93 & 6.86 \\
\hline Broadminded & 4.90 & 4.62 & 4.88 & 5.20 & 5.75 \\
\hline Capable & 3.98 & 4.08 & 4.60 & 4.01 & 5.43 \\
\hline Clean & 4.07 & 4.59 & 4.82 & 4.72 & 3.78 \\
\hline Courageous & 4.37 & 4.59 & 4.48 & 4.79 & 4.36 \\
\hline Forgiving & 5.11 & 4.75 & 4.62 & 4.94 & 5.24 \\
\hline Helpful & 4.35 & 4.59 & 4.66 & 4.37 & 4.50 \\
\hline Honest & 3.11 & 4.00 & 4.65 & 4.37 & 4.50 \\
\hline Imaginative & 4.90 & 4.93 & 4.52 & 4.34 & 4.80 \\
\hline Independent & 4.66 & 4.82 & 4.74 & 5.22 & 3.62 \\
\hline Intellectual & 3.95 & 4.84 & 4.86 & 5.26 & 4.83 \\
\hline Logical & 5.35 & 4.68 & 4.18 & 5.05 & 5.54 \\
\hline Loving & 4.84 & 5.07 & 5.78 & 5.26 & 4.41 \\
\hline Loya 1 & 4.14 & 4.51 & 4.25 & 4.62 & 5.09 \\
\hline Obedient & 3.46 & 4.07 & 4.41 & 4.89 & 6.01 \\
\hline Polite & 3.58 & 3.97 & 4.24 & 4.14 & 3.73 \\
\hline Responsible & 3.86 & 3.99 & 4.54 & 5.18 & 4.71 \\
\hline Self Controlled & 3.53 & 4.61 & 4.99 & 5.34 & 5.81 \\
\hline
\end{tabular}


A multivariate analysis of variance was performed, using Highest Degree Held as the independent variable and Rokeach Instrumental Values as the dependent variables. With 72 and 1862 degrees of freedom, the Wilks' lambda value $(F=1.4399)$ was significant at the .05 level of confidence $(p=.012)$. With the rejection of the statistical hypothesis for the multivariate analysis, univariate analyses of variance were performed on the dependent variables, using a .05 level of confidence for each test. The statistical hypothesis that $\mu_{1}=\mu_{2}=. .=\mu_{5}$ was rejected for two instrumental values: Clean and Intellectual (See Table LXXXV.) On each of these two variables, a Modified LSD was performed for each pair-wise mean comparison using a .05 level of confidence (See Table $L X X X V I$ ). Group means and standard deviations were presented in Tables LXXXIII and LXXXIV. As may be seen, instructors with Associate degrees placed more value on the value Clean than did instructors with Doctorates and Master's degrees. Instructors with Doctorates placed greater value on Intellectual than did instructors with Bachelor's and Associate degrees, while instructors with Master's degrees placed greater value on Intellectual than did instructors with Bachelor's degrees. 
TABLE LXXXV

ANALYSIS OF VARIANCE TABLE FOR HIGHEST DEGREE HELD USING INSTRUMENTAL VALUES AS DEPENDENT VARIABLES

\begin{tabular}{lrrrrrr}
\hline \multicolumn{1}{c}{ Variable } & Hy SS & Error SS & Hy MS & Error MS & F* & Sig. of F \\
\hline Ambitious & 123.798 & 13277.098 & 30.949 & 27.432 & 1.128 & .342 \\
Broadminded & 80.182 & 10911.098 & 20.045 & 22.544 & 0.889 & .470 \\
Capable & 64.464 & 8440.785 & 16.366 & 17.440 & 0.938 & .441 \\
Clean & 459.833 & 10204.405 & 114.958 & 21.083 & 5.453 & .000 \\
Courageous & 111.808 & 10110.552 & 27.592 & 20.890 & 1.338 & .255 \\
Forgiving & 75.330 & 11044.773 & 18.832 & 22.820 & 0.825 & .509 \\
Helpful & 149.547 & 10155.120 & 37.387 & 20.982 & 1.782 & .131 \\
Honest & 50.593 & 8099.767 & 12.648 & 16.735 & 0.756 & .554 \\
Imaginative & 123.877 & 11219.129 & 30.969 & 23.180 & 1.336 & .255 \\
Independent & 120.433 & 11215.486 & 30.108 & 23.172 & 1.299 & .269 \\
Intellectual & 647.785 & 11211.430 & 161.946 & 23.164 & 6.991 & .000 \\
Logical & 161.948 & 18413.234 & 40.487 & 38.044 & 1.064 & .374 \\
Loving & 112.336 & 19273.386 & 28.084 & 40.751 & 0.689 & .600 \\
Loyal & 36.159 & 16663.661 & 9.040 & 34.429 & 0.263 & .902 \\
Obedient & 130.141 & 8440.256 & 32.535 & 17.439 & 1.866 & .115 \\
Polite & 79.487 & 7728.186 & 19.872 & 15.967 & 1.245 & .291 \\
Responsible & 59.861 & 8478.486 & 14.965 & 17.518 & 0.854 & .491 \\
Self Control. & 83.206 & 10595.800 & 20.801 & 21.892 & 0.950 & .435 \\
\hline & & & & & & \\
\hline
\end{tabular}

${ }^{2} \mathrm{df}=4$ and 484 
TABLE LXXXVI

SIGNIFICANT PAIR-WISE MEAN COMPARISONS BETWEEN LEVELS OF HIGHEST DEGREE HELD ON THE ROKEACH INSTRUMENTAL VALUES

RVS Instrumental Values

Pair-wise Group Comparisons*

Clean

$1-4, \quad 2-4$

Intellectual

$1-3, \quad 1-4,2-3$

*Degree: Doctorate (1); Master's (2); Bachelor's (3); Associate (4); Other (5)

Values by Other Employment

Work values, terminal values, and instrumental values were examined by faculty classified as having/not having other employment.

Work Values

OWVI scale means and standard deviations for faculty classified as having other employment or no other employment are presented in Table LXXXVII. For those with other jobs, the means ranged from 19.51 (Solitude) to 29.77 (Task Satisfaction). For those without other employment, the means ranged from 18.13 (Solitude) to 32.31 (Task Satisfaction). (See Table LXXXVII.)

A multivariate analysis of variance was performed with 0 ther Job/No Other Job as the independent variable and the scales of the OWVI as dependent variables. The $F$ value for Wilks' lambda test was 6.694 ; this was significant at the .05 level of confidence $(p=.000)$. 
TABLE LXXXVII

SCALE MEANS AND STANDARD DEVIATIONS ON THE OHIO WORK VALUES INVENTORY FOR THE OTHER/NO OTHER JOB VARIABLE

\begin{tabular}{|c|c|c|c|c|c|c|}
\hline \multirow[t]{2}{*}{ OWVI Scale } & \multicolumn{2}{|c|}{ Other Job } & \multicolumn{2}{|c|}{ No Other Job } & \multicolumn{2}{|c|}{ Total } \\
\hline & Mean & S.D. & Mean & S.D. & Mean & S.D. \\
\hline Altruism & 26.90 & 5.02 & 27.78 & 5.47 & 27.44 & 5.33 \\
\hline Object Orientation & 20.36 & 6.56 & 18.43 & 6.92 & 19.16 & 6.83 \\
\hline Security & 24.44 & 6.43 & 24.85 & 6.61 & 24.98 & 6.54 \\
\hline Control & 21.87 & 6.58 & 20.37 & 6.37 & 20.95 & 6.47 \\
\hline Self Realization & 29.44 & 4.44 & 31.38 & 3.46 & 30.64 & 3.99 \\
\hline Independence & 26.93 & 4.51 & 27.33 & 4.80 & 27.19 & 4.69 \\
\hline Money & 24.52 & 6.75 & 22.80 & 7.12 & 23.48 & 7.04 \\
\hline Task Satisfaction & 29.77 & 5.11 & 32.31 & 3.35 & 31.33 & 4.31 \\
\hline Solitude & 19.51 & 5.63 & 18.13 & 5.59 & 18.67 & 5.67 \\
\hline Ideas/Data & 26.66 & 4.51 & 28.48 & 4.66 & 27.81 & 4.68 \\
\hline Prestige & 20.35 & 6.51 & 18.20 & 6.17 & 19.03 & 6.37 \\
\hline
\end{tabular}

With the rejection of the statistical hypothesis for the multivariate analysis, univariate analyses of variance were performed on the 11 variables. Eight statistical hypotheses were rejected at the .05 level of confidence. Significant differences were found on Object Orientation, Control, Self Realization, Money, Task Satisfaction, Solitude, Ideas/Data and Prestige with those instructors who hold Other 
Jobs placing less value on Self Realization, Task Satisfaction and Ideas/Data, while those with No 0ther Job placed less value on Object Orientation, Control, Money, Solitude and Prestige. These are shown in Table LXXXVIII.

TABLE LXXXVIII

ANALYSIS OF VARIANCE TABLE FOR OTHER JOB/NO OTHER JOB USING WORK VALUES AS DEPENDENT VARIABLES

\begin{tabular}{lrrrrrr}
\hline \multicolumn{1}{c}{ Variable } & Hy SS & Error SS & Hy MS & Error MS & F* & Sig. of F \\
\hline Altruism & 90.038 & 13902,702 & 90.038 & 28.143 & 3.199 & .074 \\
Object Orient. & 435.329 & 22722.405 & 435.329 & 45.997 & 9.464 & .002 \\
Security & 19.742 & 21152.062 & 19.742 & 42.818 & 0.461 & .497 \\
Control & 263.444 & 20554.741 & 263.444 & 14.609 & 6.331 & .012 \\
Self Real. & 440.107 & 7371.149 & 440.107 & 14.921 & 29.495 & .000 \\
Independence & 19.209 & 10867.178 & 19.209 & 21.998 & 0.873 & .351 \\
Money & 345.571 & 24097.066 & 345.571 & 48.779 & 7.084 & .008 \\
Task Satis. & 756.575 & 8331.780 & 756.575 & 16.866 & 44.858 & .000 \\
Solitude & 223.619 & 15521.040 & 223.619 & 31.419 & 7.117 & .008 \\
Ideas/Data & 387.098 & 10461.096 & 387.098 & 21.176 & 18.280 & .000 \\
Prestige & 536.855 & 19582.046 & 536.855 & 39.640 & 13.543 & .000 \\
\hline *df = 1, 494 & & & & & & \\
\hline
\end{tabular}

Rokeach Terminal Values

Scale means and standard deviations of the ranks of the 18 terminal values for faculty classified by Other Job/No Other Job are 
shown in Table $L X X X I X$. For those with other jobs, the mean ranks ranged from 12.65 (Social Recognition) to 6.17 (Health). For those with no other employment, the mean ranks ranged from 13.60 (National Security) to 5.23 (Self Respect). (See Table LXXXIX.) 
TABLE LXXXIX

SCALE MEANS AND STANDARD DEVIATIONS ON THE ROKEACH TERMINAL VALUES SURVEY FOR THE OTHER JOE/NO OTHER JOB VARIABLE

\begin{tabular}{|c|c|c|c|c|c|c|}
\hline \multirow[t]{2}{*}{ RVS Value } & \multicolumn{2}{|c|}{ other Job } & \multicolumn{2}{|c|}{ No Other Job } & \multicolumn{2}{|c|}{ Total } \\
\hline & Mean & S.D. & Mean & S.D. & Mean & S.D. \\
\hline A Comfortable Life & 11.14 & 4.60 & 11.69 & 4.61 & 11.47 & 4.60 \\
\hline An Exciting Life & 10.23 & 4.91 & 11.02 & 4.44 & 10.68 & 4.66 \\
\hline A Sense of Accomp. & 8.46 & 4.83 & 7.31 & 4.29 & 7.74 & 4.53 \\
\hline A World at Peace & 9.97 & 5.05 & 10.06 & 5.15 & 10.02 & 5.10 \\
\hline A World of Beauty & 10.80 & 4.47 & 11.54 & 4.05 & 11.25 & 4.22 \\
\hline Equality & 10.92 & 4.89 & 11.26 & 4.16 & 11.13 & 4.46 \\
\hline Family Security & 7.07 & 5.05 & 6.23 & 4.27 & 6.54 & 4.59 \\
\hline Freedom & 7.10 & 4.10 & 6.90 & 4.10 & 6.96 & 4.10 \\
\hline Health & 6.17 & 4.54 & 5.43 & 3.38 & 5.73 & 3.90 \\
\hline Inner Harmony & 7.47 & 4.65 & 7.12 & 4.37 & 7.24 & 4.48 \\
\hline Mature Love & 8.47 & 4.82 & 8.62 & 4.33 & 8.57 & 4.52 \\
\hline National Security & 12.47 & 4.72 & 13.60 & 4.31 & 13.13 & 4.53 \\
\hline Pleasure & 11.61 & 4.69 & 13.10 & 3.73 & 12.54 & 4.17 \\
\hline Salvation & 11.55 & 6.42 & 12.47 & 6.86 & 12.14 & 6.70 \\
\hline Self Respect & 6.81 & 4.41 & 5.23 & 3.64 & 5.85 & 4.02 \\
\hline Social Recognition & 12.65 & 4.22 & 13.51 & 3.58 & 13.18 & 3.85 \\
\hline True Friendship & 9.31 & 4.31 & 8.72 & 4.09 & 8.97 & 4.18 \\
\hline Wisdom & 8.82 & 5.22 & 7.09 & 4.46 & 7.78 & 4.85 \\
\hline
\end{tabular}


A multivariate analysis of variance was performed, with Other Job/No Other Job as the independent variable and the terminal values of the RVS as dependent variables. The F value for the Wilks' lambda test was 3.704 ; this was significant at the .05 level of confidence $(p=.000)$.

The statistical hypothesis for the multivariate analysis was rejected; univariate analyses of variance were performed on the RVS 18 dependent variables (See Table XC). Nine statistical hypotheses were rejected at the .05 level of confidence. Significant differences were found on the variables of An Exciting Life, A Sense of Accomplishment, Family Security, Health, National Security, Pleasure, Self Respect, Social Recognition and Wisdom, with those instructors holding No Other Job placing less value on the variables of An Exciting Life, National Security, Pleasure, and Social Recognition, while those instructors who held Other Job placing less value on A Sense of Accomplishment, Family Security, Health, Self Respect, and Wisdom. 
TABLE XC

ANALYSIS OF VARIANCE TABLE FOR OTHER JOB/NO OTHER JOB USING ROKEACH TERMINAL VALUES AS DEPENDENT VARIABLES

\begin{tabular}{lrrrrrrr}
\hline RVS Variable & Hy SS & Error SS & Hy MS & Error MS & $F^{*}$ & Sig. of F \\
\hline A Comfort. Life & 34.645 & 10471.103 & 34.645 & 21.240 & 1.663 & .203 \\
An Excit. Life & 89.350 & 10535.915 & 89.350 & 21.371 & 4.181 & .041 \\
A Sense of Acc. & 153.345 & 9995.091 & 153.345 & 20.274 & 7.764 & .006 \\
A World at Peace & 0.913 & 12894.691 & 0.913 & 26.156 & 0.035 & .852 \\
A World of Beaut. & 64.906 & 8756.476 & 64.906 & 17.762 & 3.654 & .057 \\
Equality & 13.768 & 9771.432 & 13.768 & 19.820 & 0.695 & .405 \\
Family Sec. & 81.857 & 10358.681 & 81.857 & 21.012 & 3.896 & .049 \\
Freedom & 3.934 & 8298.902 & 3.934 & 16.833 & 0.234 & .629 \\
Health & 66.160 & 7351.185 & 66.160 & 14.911 & 4.437 & .036 \\
Inner Harmony & 12.796 & 9877.063 & 12.796 & 20.035 & 0.639 & .425 \\
Mature Love & 2.811 & 10098.535 & 2.811 & 20.484 & 0.137 & .711 \\
National Sec. & 149.217 & 9840.538 & 149.217 & 19.961 & 7.476 & .006 \\
Pleasure & 258.607 & 8360.524 & 258.607 & 16.958 & 15.249 & .000 \\
Salvation & 101.053 & 22159.182 & 101.053 & 44.948 & 2.248 & .134 \\
Self Respect & 292.019 & 7701.064 & 292.019 & 15.621 & 18.694 & .000 \\
Social Recog. & 88.707 & 7253.442 & 88.707 & 14.713 & 6.029 & .014 \\
True Friend. & 39.792 & 8609.044 & 39.792 & 17.463 & 2.279 & .132 \\
Wisdom & 354.245 & 11192.172 & 354.245 & 22.702 & 15.604 & .000 \\
\hline & & & & & & \\
\hline
\end{tabular}

$\star d f=1$ and 493 
Rokeach Instrumental Values

Means and standard deviations of the ranks of the Rokeach Instrumental Values are presented separately in Table XCI for those who hold no other employment except community college teaching and those who have other employment. The mean ranks ranged from 14.22 (Obedient) to 5.80 (Honest) for those with other jobs and from 15.54 (Obedient) to 4.30 (Honest) for those without jobs other than community college teaching. A multivariate analysis of variance was performed, with other Job/No Other Job as the independent variable and the instrumental values of the RVS as dependent variables. The F value for the Wilks' lambda test was 3.704 ; this was significant at the .05 level of confidence $(p=.000)$.

With the rejection of the multivariate statistical hypothesis, univariate analyses of variance were performed on the 18 dependent variables. (See Table XCII.) Eight statistical hypotheses were rejected at the .05 level of confidence. Significant differences were found on the values of Ambitious, Clean, Honest, Logical, Loving, Obedient, Polite and Responsible, with an even split of those instructors holding Other Jobs placing less value on the variables of Honest, Logical, Loving and Responsible, and those instructors holding No Other Job placing less value on Ambitious, Clean, Obedient, and Polite. 
TAB!E XCI

SCALE MEANS AND STANDARD DEVIATIONS ON THE ROKEACH INSTRUMENTAL VALUES SURVEY FOR THE OTHER/NO OTHER JOB VARIABLE

\begin{tabular}{|c|c|c|c|c|c|c|}
\hline \multirow[t]{2}{*}{ RVS Values } & \multicolumn{2}{|c|}{ other Job } & \multicolumn{2}{|c|}{ No Other Job } & \multicolumn{2}{|c|}{ Total } \\
\hline & Mean & S.D. & Mean & S.D. & Mean & S.D. \\
\hline Ambitious & 9.75 & 5.50 & 10.76 & 5.10 & 10.36 & 5.27 \\
\hline Broadminded & 8.90 & 5.04 & 9.19 & 4.56 & 9.06 & 4.74 \\
\hline Capable & 7.72 & 4.30 & 7.41 & 4.11 & 7.71 & 4.18 \\
\hline Clean & 12.13 & 4.70 & 13.81 & 4.52 & 13.17 & 4.66 \\
\hline Courageous & 9.36 & 4.47 & 8.92 & 4.64 & 9.10 & 4.58 \\
\hline Forgiving & 9.06 & 4.78 & 9.77 & 4.76 & 9.50 & 4.76 \\
\hline Helpful & 9.05 & 4.86 & 8.35 & 4.44 & 8.62 & 4.60 \\
\hline Honest & 5.80 & 4.65 & 4.30 & 3.61 & 4.87 & 4.10 \\
\hline Imaginative & 9.84 & 5.12 & 10.43 & 4.63 & 10.19 & 4.83 \\
\hline Independent & 8.37 & 5.14 & 7.75 & 4.60 & 7.97 & 4.81 \\
\hline Intel lectual & 8.82 & 5.01 & 8.43 & 4.88 & 8.58 & 4.93 \\
\hline Logical & 10.30 & 4.94 & 9.61 & 4.61 & 10.06 & 6.14 \\
\hline Loving & 8.01 & 5.40 & 7.10 & 4.78 & 7.65 & 6.35 \\
\hline Loyal & 9.01 & 4.75 & 9.50 & 4.43 & 9.50 & 5.84 \\
\hline Obedient & 14.22 & 4.86 & 15.54 & 3.71 & 15.05 & 4.22 \\
\hline Polite & 11.93 & 4.26 & 12.99 & 3.76 & 12.59 & 3.98 \\
\hline Responsible & 7.43 & 4.56 & 5.84 & 3.79 & 6.45 & 4.17 \\
\hline Self Controlled & 11.44 & 4.44 & 11.07 & 4.82 & 11.22 & 4.68 \\
\hline
\end{tabular}


TABLE XCII

ANALYSIS OF VARIANCE TABLE FOR OTHER JOB/NO OTHER JOB USING ROKEACH INSTRUMENTAL VALUES AS DEPENDENT VARIABLES

\begin{tabular}{lrrrrrrr}
\hline RVS Variable & Hy SS & Error SS & Hy MS & Error MS & F* & Sig. of F \\
\hline Ambitious & 122.232 & 13596.691 & 122.232 & 27.636 & 4.423 & .036 \\
Broadminded & 10.141 & 11111.116 & 10.141 & 22.584 & 0.449 & .503 \\
Capable & 11.074 & 8633.908 & 11.074 & 17.549 & 0.631 & .427 \\
Clean & 327.792 & 10376.682 & 327.692 & 21.091 & 15.537 & .000 \\
Courageous & 23.703 & 10293.374 & 23.703 & 20.921 & 1.133 & .288 \\
Forgiving & 57.740 & 11140.760 & 57.740 & 22.662 & 2.548 & .111 \\
Helpful & 56.571 & 10383.641 & 56.571 & 21.105 & 2.680 & .102 \\
Honest & 257.642 & 8011.826 & 257.642 & 16.284 & 15.822 & .000 \\
Imaginative & 42.028 & 11462.654 & 42.028 & 23.298 & 1.804 & .180 \\
Independent & 42.077 & 11391.923 & 42.077 & 23.154 & 1.812 & .178 \\
Intellectual & 16.244 & 11928.972 & 16.244 & 24.246 & 0.670 & .413 \\
Logical & 150.403 & 18528.010 & 150.403 & 37.659 & 3.994 & .046 \\
Loving & 243.814 & 19700.599 & 243.814 & 40.042 & 6.089 & .014 \\
Loyal & 0.711 & 16852.739 & 0.711 & 34.254 & 0.021 & .886 \\
Obedient & 210.356 & 8587.379 & 210.356 & 17.454 & 12.052 & .001 \\
Polite & 132.813 & 7712.944 & 132.813 & 15.677 & 8.472 & .004 \\
Responsible & 289.192 & 8273.042 & 289.192 & 16.815 & 17.198 & .000 \\
Self Control. & 14.098 & 10790.852 & 14.098 & 21.933 & 0.643 & .423 \\
\hline & & & & & & & \\
\hline
\end{tabular}

$\star \mathrm{df}=1$ and 492 
Values by Location of College

Work values, terminal values, and instrumental values were examined by location of college (metropolitan, other urban, small city/rural).

Work Values

OW'VI scale means and standard deviations for three categories of location of college where teaching are presented in Table XCIII. For metropolitan community colleges, the means ranged from 18.32 (Solitude) to 30.86 (Task Satisfaction). For Other Urban community colleges, the means ranged from 19.74 (Solitude) to 31.02 (Task Satisfaction). For community colleges located in small city and rural settings, the means ranged from 17.96 (Solitude) to 32.16 (Task Satisfaction).

A multivariate analys is of variance was performed, using College Teaching Location as the independent variable and work values as dependent variables. With 22 and 968 degrees of freedom, the Wilks' lambda value $(F=2.0313)$ was significant at the .05 level of confidence $(p=.003)$. The statistical hypothesis for the multivariate analysis was rejected; univariate analyses of variance were performed on the dependent variables, using a .05 level of confidence for each test. The statistical hypothesis that $\mu_{1}=\mu_{2}=\mu_{3}$ was rejected for six work values: Object Orientation, Self Realization, Money, Task Satisfaction, Solitude, and Prestige. (See Table XCIV.) 
TABLE XCIII

SCALE MEANS AND STANDARD DEVIATIONS ON THE OHIO WORK VALUES INVENTORY FOR LEVELS OF COLLEGE LOCATION

\begin{tabular}{|c|c|c|c|c|c|c|}
\hline \multirow[t]{2}{*}{ OWVI Value } & \multicolumn{2}{|c|}{$\begin{array}{l}\text { Mietro } \\
\text { (Group 1) }\end{array}$} & \multicolumn{2}{|c|}{$\begin{array}{l}\text { Other Urban } \\
\text { (Group 2) }\end{array}$} & \multicolumn{2}{|c|}{$\begin{array}{c}\text { Small City/Rura) } \\
\text { (Group 3) }\end{array}$} \\
\hline & Mean & S.D. & Mean & S.D. & Mean & S.D. \\
\hline Altruism & 27.37 & 5.49 & 27.07 & 5.17 & 27.89 & 5.30 \\
\hline Object Orientation & 19.13 & 6.98 & 20.22 & 6.50 & 18.11 & 6.86 \\
\hline Security & 24.37 & 6.80 & 24.97 & 6.20 & 24.74 & 6.61 \\
\hline Control & 20.56 & 6.13 & 24.97 & 7.08 & 24.74 & 6.21 \\
\hline Self Realization & 30.01 & 4.17 & 30.24 & 4.36 & 31.63 & 3.15 \\
\hline Independence & 26.82 & 4.76 & 27.52 & 4.59 & 27.26 & 4.71 \\
\hline Money & 23.13 & 6.95 & 24.67 & 6.76 & 22.65 & 7.30 \\
\hline Task Satisfaction & 30.86 & 4.58 & 31.02 & 4.73 & 32.16 & 3.35 \\
\hline Sol itude & 18.32 & 5.37 & 19.74 & 6.09 & 17.96 & 5.40 \\
\hline Ideas/Data & 27.54 & 4.93 & 28.06 & 4.54 & 27.84 & 4.55 \\
\hline Prestige & 18.71 & 6.39 & 20.06 & 6.63 & 18.33 & 5.97 \\
\hline
\end{tabular}


TABLE XCIV

ANALYSIS OF VARIANCE TABLE FOR COLLEGE LOCATION USING WORK VALUES AS DEPENDENT VARIABLES

\begin{tabular}{|c|c|c|c|c|c|c|}
\hline Variable & Hy SS & Error SS & Hy MS & Error MS & $F^{*}$ & Sig. of $F$ \\
\hline Altruism & 56.655 & 14037.916 & 28.327 & 28.359 & 0.999 & .369 \\
\hline Object Orient. & 359.858 & 22801.291 & 179.929 & 46.063 & 3.906 & .021 \\
\hline Security & 31.222 & 21196.282 & 15.611 & 42.821 & 0.365 & .695 \\
\hline Control & 48.686 & 20786.850 & 24.343 & 41.994 & 0.580 & .560 \\
\hline Self Realiz. & 232.132 & 7691.083 & 116.066 & 15.538 & 7.470 & .001 \\
\hline Independence & 41.962 & 10878.916 & 20.981 & 21.978 & 0.955 & .386 \\
\hline Money & 361.423 & 24244.915 & 180.711 & 48.980 & 3.690 & .026 \\
\hline Task Satis. & 162.645 & 9067.686 & 81.323 & 18.319 & 4.439 & .012 \\
\hline Sol itude & 290.305 & 15666.996 & 145.153 & 31.651 & 4.586 & .011 \\
\hline Ideas/Data & 22.607 & 10857.499 & 11.303 & 21.934 & 0.515 & .598 \\
\hline Prestige & 269.954 & 19900.466 & 134.977 & 40.203 & 3.357 & .036 \\
\hline \multicolumn{7}{|l|}{$\star d f=2$ and 495} \\
\hline \multicolumn{7}{|c|}{$\begin{array}{l}\text { On each of these six variables, a Modified LSD was performed for } \\
\text { each pair-wise mean comparison, using a } .05 \text { level of confidence. Group }\end{array}$} \\
\hline \multirow{2}{*}{\multicolumn{7}{|c|}{$\begin{array}{l}\text { means and standard deviations were presented in Table XCIII. A } \\
\text { summary of significant differences between group means is found in Table }\end{array}$}} \\
\hline & & & & & & \\
\hline \multicolumn{7}{|c|}{ XCV. As may be seen, Other Urban instructors placed greater value on } \\
\hline \multicolumn{7}{|c|}{$\begin{array}{l}\text { Object Orientation than did Small City/Rural instructors. Both Metro } \\
\text { area and Other Urban area instructors placed less value on Self }\end{array}$} \\
\hline
\end{tabular}


Realization than did Small City/Rural instructors. Small City/Rural instructors placed less value on Money than did Other Urban instructors. Metro Area instructors placed less value on Task Satisfaction than did Small City/Rural instructors. Small City/Rural instructors placed less value on Solitude than did Other Urban instructors, while Small City/Rural instructors placed less value on Prestige than did Other Urban instructors.

TABLE XCV

SIGNIFICANT PAIR-WISE MEAN COMPARISONS BETWEEN LEVELS OF COLLEGE TEACHING LOCATION ON THE OHIO WORK VALUES INVENTORY

\begin{tabular}{ll}
\hline \multicolumn{1}{c}{ OWVI Scales } & Pair-wise Group Comparisons* \\
\hline Object Orientation & $2-3$ \\
Self Realization & $1-3,2-3$ \\
Money & $1-3$ \\
Task Satisfaction & $1-3$ \\
Solitude & $2-3$ \\
Prestige & $2-3$ \\
\hline
\end{tabular}

*College Location: Metro (1); Other Urban (2); and Small City/Rural (3)

Rokeach Terminal Values

In Table XCVI are the scale means and standard deviations of the ranks of the 18 terminal values for faculty at community colleges classified as Metropolitan, Other Urban, and Small City/Rural. For 
TABLE XCVI

SCALE MEANS AND STANDARD DEVIATIONS ON THE ROKEACH TERMINAL VALUE SURVEY FOR LEVELS OF COLLEGE TEACHING LOCATION

\begin{tabular}{|c|c|c|c|c|c|c|}
\hline \multirow[t]{2}{*}{ RVS Scale } & \multicolumn{2}{|c|}{$\begin{array}{l}\text { Metro } \\
\text { (Group 1) }\end{array}$} & \multicolumn{2}{|c|}{$\begin{array}{l}\text { Other Urban } \\
\text { (Group 2) }\end{array}$} & \multicolumn{2}{|c|}{$\begin{array}{c}\text { Sma l } \text { City/Rural } \\
\text { (Group 3) }\end{array}$} \\
\hline & Mean & S.D. & Mean & S.D. & Mean & S.D. \\
\hline A Comfortable Life & 11.87 & 4.66 & 10.98 & 4.51 & 11.55 & 4.63 \\
\hline An Exciting Life & 10.86 & 4.72 & 10.31 & 4.59 & 10.93 & 4.65 \\
\hline A Sense of Accomp. & 7.56 & 4.51 & 7.91 & 4.87 & 7.78 & 4.21 \\
\hline A World at Peace & 9.76 & 5.17 & 9.87 & 5.12 & 10.46 & 5.01 \\
\hline A World of Beauty & 11.17 & 4.35 & 11.26 & 4.25 & 11.33 & 4.08 \\
\hline Equality & 11.17 & 4.36 & 10.79 & 4.54 & 11.44 & 4.48 \\
\hline Family Security & 7.21 & 4.85 & 6.39 & 4.64 & 5.97 & 4.17 \\
\hline Freedom & 7.16 & 4.05 & 6.91 & 4.15 & 6.81 & 4.13 \\
\hline Health & 5.94 & 4.11 & 5.74 & 3.88 & 5.48 & 3.70 \\
\hline Inner Harmony & 7.30 & 4.66 & 7.19 & 4.26 & 7.27 & 4.50 \\
\hline Mature Love & 8.69 & 4.75 & 8.39 & 4.33 & 8.64 & 4.49 \\
\hline National Security & 12.73 & 4.70 & 13.09 & 4.63 & 13.61 & 4.22 \\
\hline Pleasure & 12.53 & 4.33 & 12.33 & 4.24 & 12.78 & 3.93 \\
\hline Salvation & 12.13 & 6.90 & 12.60 & 6.34 & 11.69 & 6.87 \\
\hline Self Respect & 5.75 & 3.81 & 6.15 & 4.44 & 5.64 & 3.80 \\
\hline Social Recognition & 12.83 & 4.03 & 13.20 & 4.02 & 13.54 & 3.44 \\
\hline True Friendship & 9.04 & 3.87 & 9.44 & 4.53 & 8.42 & 4.12 \\
\hline Wisdom & 7.35 & 4.54 & 8.34 & 5.07 & 7.66 & 4.93 \\
\hline
\end{tabular}


faculty at Metropolitan colleges, the mean ranks ranged from 12.83 (Social Recognition) to 5.75 (Self Respect). For Other Urban faculty, the mean ranks ranged from 13.20 (Social Recognition) to 5.74 (Health). For Small City/Rural faculty, the mean ranks ranged from 13.61 (National Security) to 5.48 (Health).

A multivariate analysis of variance was performed, using College Teaching Location as the independent variable and Rokeach Terminal Values as the dependent variables. With 36 and 952 degrees of freedom, the Wilks' values $(F=0.9281)$ was not significant at the .05 level of confidence. The statistical hypothesis was not rejected.

\section{Rokeach Instrumental Values}

In Table XCVII are the means and standard deviations of the ranks of the Rokeach Instrumental Values for faculty at community colleges classified as Metropolitan, Other Urban, and Small City/Rural. The mean ranks for Metropolitan faculty ranged from 14.86 (Obedient) to 5.52 (Honest). For Other Urban faculty, the mean ranks ranged from 15.28 (Obedient) to 4.96 (Honest). For Small City/Rural community college faculty, the mean ranks ranged from 15.06 (Obedient) to 4.10 (Honest). A multivariate analysis of variance was performed, using College Teaching Location as the independent variable and Rokeach Instrumental Values as dependent variables. With 36 and 950 degrees of freedom, the Wilks' lambda value $(F=1.2252)$ was not significant at the .05 level of confidence $(p=.173)$. The statistical hypothesis was not rejected. 
TABLE XCVII

SCALE MEANS AND STANDARD DEVIATIONS ON THE ROKEACH INSTRUMENTAL VALUES SURVEY FOR THE LEVELS OF COLLEGE TEACHING LOCATION

\begin{tabular}{|c|c|c|c|c|c|c|}
\hline \multirow[t]{2}{*}{ RVS Scales } & \multicolumn{2}{|c|}{$\begin{array}{l}\text { Metro } \\
\text { (Group 1) }\end{array}$} & \multicolumn{2}{|c|}{$\begin{array}{l}\text { Other Urban } \\
\text { (Group 2) }\end{array}$} & \multicolumn{2}{|c|}{$\begin{array}{c}\text { Small City/Rural } \\
\text { (Group 3) }\end{array}$} \\
\hline & Mean & S.D. & Mean & S.D. & Mean & S.D. \\
\hline Ambitious & 10.99 & 5.07 & 9.98 & 5.38 & 10.08 & 5.36 \\
\hline Broadminded & 9.02 & 4.80 & 8.93 & 4.71 & 9.28 & 4.74 \\
\hline Capable & 7.37 & 4.02 & 7.66 & 4.43 & 7.55 & 4.11 \\
\hline Clean & 13.59 & 4.42 & 12.77 & 4.78 & 13.12 & 4.79 \\
\hline Courageous & 9.17 & 4.34 & 8.88 & 4.83 & 9.21 & 4.59 \\
\hline Forgiving & 9.23 & 4.61 & 9.72 & 4.64 & 9.56 & 5.04 \\
\hline Helpful & 8.88 & 4.74 & 8.82 & 4.59 & 8.16 & 4.42 \\
\hline Honest & 5.52 & 4.33 & 4.96 & 4.06 & 4.10 & 3.76 \\
\hline Imaginative & 10.06 & 5.02 & 9.82 & 4.69 & 10.73 & 4.78 \\
\hline Independent & 7.70 & 4.83 & 7.92 & 4.81 & 8.36 & 4.81 \\
\hline Intellectual & 7.96 & 4.84 & 8.40 & 5.01 & 9.49 & 4.84 \\
\hline Logical & 9.92 & 4.15 & 9.93 & 4.67 & 10.38 & 4.82 \\
\hline Loving & 7.69 & 5.23 & 8.15 & 5.48 & 7.07 & 4.59 \\
\hline Loyal & 9.56 & 4.93 & 9.73 & 4.22 & 9.23 & 4.45 \\
\hline Obedient & 14.86 & 4.51 & 15.28 & 4.05 & 15.06 & 4.07 \\
\hline Polite & 12.79 & 3.94 & 12.25 & 4.26 & 12.71 & 3.74 \\
\hline Responsible & 6.60 & 4.01 & 6.85 & 4.35 & 5.89 & 4.13 \\
\hline Self Controlled & 11.56 & 4.55 & 11.12 & 5.03 & 10.99 & 4.45 \\
\hline
\end{tabular}


Relationships Between OWVI and RVS Values

A coefficient of correlation was calculated between each OWVI

scale and each RVS sub-scale. The correlations between work values and terminal values are presented in Table XCVIII. 
TABLE XCVIII

CORRELATIONS BETWEEN OWVI AND RVS TERMINAL SCALES

\begin{tabular}{|c|c|c|c|c|c|c|c|c|c|c|c|}
\hline \multirow[b]{2}{*}{ RVS Value } & \multicolumn{11}{|c|}{ OWVI SCALE } \\
\hline & Alt & Obo & Sec & Con & SeR & Ind & Mon & TaS & Sol & $\mathrm{I} / \mathrm{D}$ & Pre \\
\hline $\begin{array}{l}\text { A Comfort. Life } \\
\text { An Excit. Life } \\
\text { A Sense of Accom. } \\
\text { A World at Peace } \\
\text { A World of Beauty } \\
\text { Equality } \\
\text { Family Security } \\
\text { Freedom } \\
\text { Health } \\
\text { Inner Harmony } \\
\text { Mature Love } \\
\text { National Security } \\
\text { Pleasure } \\
\text { Salvation } \\
\text { Self Respect } \\
\text { Social Recog. } \\
\text { True Friendship } \\
\text { Wisdom }\end{array}$ & $\begin{array}{l}-.20 \\
-.06 \\
-.01 \\
+.10 \\
-.04 \\
+.11 \\
+.09 \\
-.07 \\
-.01 \\
+.08 \\
-.04 \\
-.08 \\
-.15 \\
+.09 \\
+.02 \\
-.13 \\
+.10 \\
+.09\end{array}$ & $\begin{array}{l}+.07 \\
+.06 \\
-.03 \\
+.03 \\
-.00 \\
+.01 \\
+.03 \\
-.03 \\
-.00 \\
-.07 \\
-.04 \\
+.26 \\
+.03 \\
+.01 \\
-.11 \\
+.02 \\
-.12 \\
-.15\end{array}$ & $\begin{array}{l}+.10 \\
-.14 \\
-.13 \\
+.03 \\
-.13 \\
-.02 \\
+.10 \\
-.05 \\
-.02 \\
+.04 \\
-.05 \\
+.12 \\
+.02 \\
+.16 \\
-.03 \\
-.02 \\
-.02 \\
-.08\end{array}$ & $\begin{array}{l}+.16 \\
+.05 \\
+.00 \\
-.13 \\
-.07 \\
-.10 \\
+.10 \\
-.02 \\
-.09 \\
-.07 \\
-.10 \\
+.18 \\
+.06 \\
+.14 \\
-.09 \\
+.19 \\
-.13 \\
-.11\end{array}$ & $\begin{array}{l}-.06 \\
-.01 \\
+.09 \\
+.03 \\
-.14 \\
-.03 \\
+.02 \\
+.07 \\
+.15 \\
-.02 \\
+.00 \\
-.18 \\
-.21 \\
+.06 \\
+.18 \\
-.21 \\
+.19 \\
+.21\end{array}$ & $\begin{array}{l}+.08 \\
+.11 \\
+.05 \\
+.00 \\
-.13 \\
-.08 \\
-.04 \\
+.22 \\
+.05 \\
-.02 \\
-.06 \\
-.02 \\
-.02 \\
-.12 \\
+.06 \\
-.06 \\
-.00 \\
+.08\end{array}$ & $\begin{array}{l}+.25 \\
-.03 \\
-.08 \\
+.02 \\
-.19 \\
-.10 \\
+.10 \\
+.04 \\
-.00 \\
-.04 \\
-.03 \\
+.16 \\
+.06 \\
+.01 \\
-.04 \\
-.01 \\
-.02 \\
-.12\end{array}$ & $\begin{array}{l}-.03 \\
+.02 \\
+.05 \\
+.04 \\
-.17 \\
-.11 \\
+.05 \\
+.10 \\
+.16 \\
+.08 \\
+.01 \\
-.22 \\
-.19 \\
-.14 \\
+.18 \\
-. .22 \\
+.22 \\
+.23\end{array}$ & $\begin{array}{l}+.16 \\
+.13 \\
+.04 \\
-.00 \\
+.08 \\
-.08 \\
-.04 \\
+.14 \\
-.05 \\
-.05 \\
-.09 \\
+.16 \\
+.17 \\
-.09 \\
-.13 \\
+.08 \\
-.22 \\
-.13\end{array}$ & $\begin{array}{l}-.14 \\
+.10 \\
+.10 \\
+.14 \\
+.03 \\
+.06 \\
-.04 \\
+.15 \\
+.02 \\
-.02 \\
+.02 \\
-.13 \\
-.16 \\
-.22 \\
+.01 \\
-.12 \\
+.01 \\
+.26\end{array}$ & $\begin{array}{l}+.03 \\
+.12 \\
+.10 \\
-.03 \\
-.03 \\
-.07 \\
-.01 \\
-.03 \\
-.16 \\
-.03 \\
-.05 \\
+.08 \\
+.03 \\
+.06 \\
-.11 \\
+.34 \\
-.08 \\
-.14\end{array}$ \\
\hline
\end{tabular}

Note: Terminal value ranks were reversed to achieve a positive relation between ranks and importance of the value. 
The following is a summary of the statistically significant correlations between scales of the OWVI and RVS terminal values, with a level of significance at .05 or less. (See Table IC.) Altruism was negatively correlated with A Comfortable Life, Pleasure, and Social Recognition, while positively correlated with A World at Peace, Equality, Family Security, Salvation, True Friendship, and Wisdom. Thus, those who place greater value on Altruism tended to place lesser value (rank) on A Comfortable Life, Pleasure, and Social Recognition and greater value on A World at Peace, Equality, Family Security, Salvation, True Friendship, and Wisdom. The value of Object Orientation was negatively correlated with Self Respect, True Friendship and Wisdom, while positively correlated with National Security. Thus, those who place greater value on Object Orientation tended to place lesser value on Self Respect, True Friendship, and Wisdom and greater value on National Security. Job Security was negatively correlated with An Exciting Life, A Sense of Accomplishment, and A World of Beauty, while positively correlated with A Comfortable Life, Family Security, National Security, and Salvation. Control was negatively correlated with A World at Peace, Equality, Mature Love, Self Respect, True Friendship, and Wisdom, while positively correlated with A Comfortable Life, Family Security, National Security, Salvation, and Social Recognition. Self Realization was negatively correlated with A World of Beauty, National Security, Pleasure, and Social Recognition while positively correlated with A Sense of Accomplishment, Health, Self Respect, True Friendship, and Wisdom. Independence was negatively correlated with A World of Beauty and Salvation and positively correlated with An Exciting Life and 
TABLE IC

PROBABILITIES ASSOCIATED WITH THE STATISTICALLY SIGNIFICANT CORRELATIONS BETWEEN THE OWVI SCALES AND THE RVS TERMINAL VALUES

\begin{tabular}{|c|c|c|c|c|c|c|c|c|c|c|c|}
\hline \multirow[b]{2}{*}{ RVS Value } & \multicolumn{11}{|c|}{ OWVI } \\
\hline & Alt & obo & Sec & Con & SeR & Ind & Mon & TaS & Sol & $I / D$ & Pre \\
\hline $\begin{array}{l}\text { A Comfort. Life } \\
\text { An Exciting Life } \\
\text { A Sense of Accom. } \\
\text { A World at Peace } \\
\text { A World of Beauty } \\
\text { Equality } \\
\text { Family Security } \\
\text { Freedom } \\
\text { Health } \\
\text { Mature Love } \\
\text { National Security } \\
\text { Pleasure } \\
\text { Salvation } \\
\text { Self Respect } \\
\text { Social Recogn. } \\
\text { True Friendship } \\
\text { Wisdom }\end{array}$ & $\begin{array}{l}.000 \\
.032 \\
.011 \\
.049\end{array}$ & $\begin{array}{l}.000 \\
.011 \\
.008 \\
.001\end{array}$ & $\begin{array}{r}.026 \\
.002 \\
.004 \\
.004 \\
.021\end{array}$ & $\begin{array}{l}.026 \\
.000 \\
.001 \\
.042 \\
.000 \\
.005 \\
.011\end{array}$ & $\begin{array}{l}.001 \\
.000 \\
.000 \\
\\
.000 \\
.000 \\
.000 \\
.000\end{array}$ & $\begin{array}{l}.014 \\
.004 \\
.000\end{array}$ & $\begin{array}{l}.000 \\
.029 \\
.025\end{array}$ & $\begin{array}{l}.000 \\
.018 \\
.030 \\
.000 \\
\\
.000 \\
.000 \\
.002 \\
.000 \\
.000 \\
.000 \\
.000\end{array}$ & $\begin{array}{l}.002 \\
.040 \\
.000 \\
.000 \\
.035 \\
.004 \\
\\
.000 \\
.004\end{array}$ & $\begin{array}{r}.004 \\
.000 \\
.000 \\
.009\end{array}$ & $\begin{array}{l}.008 \\
.000\end{array}$ \\
\hline
\end{tabular}


Freedom. The scale of Money was negatively correlated with A world of Beauty, Equality, and Wisdom, while positively correlated with A Comfortable Life, Family Security, and National Security. Task Satisfaction was negatively correlated with A World of Beauty, Equality, National Security, Pleasure, Salvation, and Social Recognition, while positively correlated with Freedom, Health, Self Respect, True Friendship, and Wisdom. Solitude was negatively correlated with Mature Love, Salvation, Self Respect, True Friendship, and Wisdom, while positively correlated with A Comfortable Life, An Exciting Life, Freedom, National Security, and Pleasure. Ideas/Data was negatively correlated with A Comfortable Life, National Security, Pleasure, Salvation and Social Recognition, while positively correlated with An Exciting Life, A World at Peace, A Sense of Accomplishment, Freedom, and Wisdom. Prestige was negatively correlated with Health, Self Respect and Wisdom, while positively correlated with An Exciting Life, A Sense of Accomplishment, and Social Recognition.

The correlation between the work values and instrumental yalues are shown in Table C. Table CI presents the statistically significant correlations of the OWVI and RVS Instrumental Values, and the level of significance, if the level of significance was .05 or less. 
TABLE C

CORRELATION BETWEEN OWVI AND RVS INSTRUMENTAL VALUES

\begin{tabular}{|c|c|c|c|c|c|c|c|c|c|c|c|}
\hline \multirow[b]{2}{*}{ RVS Value } & \multicolumn{11}{|c|}{ OWVI Scales } \\
\hline & Alt & ob0 & Sec & Con & SeR & Ind & Mon & TaS & Sol & $I / D$ & Pre \\
\hline $\begin{array}{l}\text { Ambitious } \\
\text { Broadminded } \\
\text { Capable } \\
\text { Clean } \\
\text { Courageous } \\
\text { Forgiving } \\
\text { Helpful } \\
\text { Honest } \\
\text { Imaginative } \\
\text { Independent } \\
\text { Intellectual } \\
\text { Logical } \\
\text { Loving } \\
\text { Loyal } \\
\text { Obedient } \\
\text { Polite } \\
\text { Responsible } \\
\text { Self Controlled }\end{array}$ & $\begin{array}{l}+.01 \\
-.03 \\
-.05 \\
-.12 \\
+.00 \\
+.15 \\
+.38 \\
+.14 \\
-.11 \\
-.09 \\
-.13 \\
-.07 \\
+.12 \\
+.02 \\
-.06 \\
-.13 \\
+.09 \\
-.03\end{array}$ & $\begin{array}{l}+.13 \\
-.02 \\
-.04 \\
+.19 \\
-.01 \\
-.01 \\
-.04 \\
-.14 \\
+.11 \\
+.03 \\
-.09 \\
+.10 \\
-.16 \\
-.03 \\
+.18 \\
+.05 \\
-.12 \\
+.02\end{array}$ & $\begin{array}{l}+.05 \\
-.08 \\
+.00 \\
+.02 \\
-.02 \\
+.08 \\
+.03 \\
-.00 \\
-.12 \\
-.09 \\
-.02 \\
-.00 \\
+.01 \\
+.05 \\
+.08 \\
+.09 \\
+.03 \\
+.12\end{array}$ & $\begin{array}{l}+.22 \\
-.18 \\
+.03 \\
+.15 \\
-.01 \\
-.08 \\
-.01 \\
-.12 \\
-.01 \\
-.03 \\
-.02 \\
+.02 \\
-.09 \\
+.03 \\
+.18 \\
+.08 \\
-.06 \\
-.02\end{array}$ & $\begin{array}{l}-.04 \\
-.03 \\
+.06 \\
-.21 \\
+.00 \\
+.00 \\
+.13 \\
+.25 \\
+.00 \\
+.02 \\
-.01 \\
-.06 \\
+.11 \\
-.04 \\
-.29 \\
-.23 \\
+.25 \\
+.05\end{array}$ & $\begin{array}{l}+.01 \\
+.01 \\
-.01 \\
-.17 \\
+.18 \\
-.04 \\
-.04 \\
+.05 \\
+.09 \\
+.15 \\
+.10 \\
+.02 \\
-.01 \\
-.03 \\
-.19 \\
-.09 \\
-.02 \\
+.09\end{array}$ & $\begin{array}{l}+.15 \\
-.08 \\
-.00 \\
+.08 \\
+.02 \\
-.01 \\
-.08 \\
-.08 \\
-.01 \\
+.04 \\
+.01 \\
-.01 \\
-.05 \\
+.02 \\
+.01 \\
+.06 \\
-.04 \\
+.04\end{array}$ & $\begin{array}{l}-.04 \\
+.01 \\
+.03 \\
-.27 \\
-.04 \\
+.01 \\
+.13 \\
+.30 \\
-.07 \\
+.04 \\
-.02 \\
-.04 \\
+.11 \\
-.03 \\
-.34 \\
-.20 \\
+.34 \\
+.08\end{array}$ & $\begin{array}{l}+.10 \\
-.04 \\
+.04 \\
+.15 \\
+.06 \\
-.11 \\
-.18 \\
-.16 \\
+.14 \\
+.10 \\
+.06 \\
+.06 \\
-.21 \\
-.07 \\
+.07 \\
+.14 \\
-.13 \\
+.01\end{array}$ & $\begin{array}{l}-.09 \\
+.10 \\
-.04 \\
-.24 \\
+.06 \\
-.05 \\
-.05 \\
+.10 \\
+.25 \\
+.14 \\
+.20 \\
+.07 \\
+.01 \\
-.05 \\
-. .29 \\
-. .21 \\
+.08 \\
-.01\end{array}$ & $\begin{array}{l}+.19 \\
-.11 \\
-.02 \\
+.02 \\
+.06 \\
-.08 \\
+.08 \\
-.16 \\
+.11 \\
-.00 \\
+.09 \\
-.06 \\
-.07 \\
-.03 \\
+.11 \\
+.09 \\
-.19 \\
-.06\end{array}$ \\
\hline
\end{tabular}

Note: Instrumental value ranks were reversed to achieve a positive relation between ranks and importance of the values. 
TABLE CI

PROBABILITIES ASSOCIATED WITH THE STATISTICALLY SIGNIFICANT CORRELATIONS BETWEEN THE OWVI SCALES AND

THE RVS INSTRUMENTAL VALUES

\begin{tabular}{|c|c|c|c|c|c|c|c|c|c|c|c|}
\hline \multirow[b]{2}{*}{ RVS Value } & \multicolumn{8}{|c|}{ OWVI } & \multirow[b]{2}{*}{ Sol } & \multirow[b]{2}{*}{$1 / 0$} & \multirow[b]{2}{*}{ Pre } \\
\hline & Alt & obo & $\mathrm{Sec}$ & Con & SeR & Ind & Mon & TaS & & & \\
\hline Ambitious & & .003 & & .000 & & & .001 & & .025 & .040 & .000 \\
\hline Broadminded & & & & .000 & & & & & & .027 & .016 \\
\hline Clean & .009 & .000 & & .001 & .000 & .000 & & .000 & .001 & .000 & \\
\hline Courageous & & & & & & .009 & & & & & \\
\hline Forgiving & .001 & & & & & & & & .010 & & \\
\hline Helpful & .000 & & .034 & & .003 & & & .005 & .000 & & \\
\hline Honest & .002 & .001 & & .010 & .000 & & & .000 & .000 & .031 & .000 \\
\hline Imaginative & .015 & .017 & .006 & & & .042 & & & .001 & .000 & .011 \\
\hline Independent & .037 & & .043 & & & .001 & & & .026 & .002 & \\
\hline Intel lectual & .003 & .049 & & & & .023 & & & & .000 & .036 \\
\hline Logical & & .024 & & & & & & & & & \\
\hline Loving & .006 & .000 & & .040 & .014 & & & .015 & .000 & & \\
\hline Obedient & & .000 & & .000 & .000 & .000 & & .000 & & .000 & .017 \\
\hline Polite & .004 & & .03 & & .00 & & & .00 & .002 & .000 & \\
\hline Responsible & & .006 & & & .000 & & & .000 & .003 & & .000 \\
\hline Self Controlled & & & .006 & & & .045 & & & & & \\
\hline
\end{tabular}


The following is a summary of the statistically significant correlations between the values of the OWVI and the subscales of the RVS Instrumental Values, with a level of significance at .05 or less.

Altruism was negatively correlated with the RVS Instrumental Values of Clean, Imaginative, Independent, Intellectual, and Polite, while positively correlated with Forgiving, Helpful, Honest, and Loving. Object Orientation was negatively correlated with Honest, Intellectual, Loving, and Responsible, while positively correlated with Ambitious, Clean, Imaginative, Logical, and Obedient. Security was negatively correlated with Imaginative and Independent, while positively correlated with Polite, and Self Controlled. Control was negatively correlated with Broadminded, Honest, and Loving, while positively correlated with Ambitious, Clean, and Obedient. Self Realization was negatively correlated with Clean, Obedient, and Polite, while positively correlated with Helpful, Honest, Loving, and Responsible. Independence was negatively correlated with Clean and Obedient, while positively correlated with Courageous, Imaginative, Independent, Intellectual, and Self Controlled. The scale of Money was positively correlated with Ambitious. Task Satisfaction was negatively correlated with Clean, Obedient, and Polite, while positively correlated with Helpful, Honest, Loving and Responsible. Solitude was negatively correlated with Forgiving, Helpful, Honest, Loving, and Responsible, while positively correlated with Ambitious, Clean, Imaginative, Independent and Polite. Ideas/Data was negatively correlated with Ambitious, Clean, Obedient, and Polite, while positively correlated with Broadminded, Honest, Imaginative, Independent and Intellectual. Finally, Prestige 
was negatively correlated with Broadminded, Honest, and Responsible, while positively correlated with Ambitious, Imaginative, Intellectual and Obedient. 


\section{CHAPTER $V$}

SUMMARY, CONCLUSIONS, IMPLICATIONS AND RECOMMENDATIONS

The purpose, procedures and results of this investigation are reported in this chapter. Conclusions, limitations, implications for further research and recommendations are also discussed.

$\underline{\text { Summary }}$

The primary purpose of this study was to examine the work values and life values of community college part-time and full-time faculty in selected teaching assignments, as measured by the Ohio Work Values Inventory and the Rokeach Value Survey (Rokeach, 1973). Using teaching status (part-time/full-time) and teaching assignment as independent variables, the following question was investigated: Are there significant differences in the work and life (terminal, instrumental) values of instructors in Oregon community colleges? Three multivariate analyses of variance were performed separately on teaching status and teaching assignment, with work values, terminal values and instrumenta? values serving as the dependent variable sets. Following each rejection of the statistical hypothesis in a multivariate analysis of variance, univariate analyses of variance were performed, followed by Modified LSDs, as appropriate, for all pair-wise mean comparisons. All statistical tests were at the .05 level of significance.

A secondary purpose of this study was to explore the values of community college faculty by selected biographical variables. Thus, for 
each of these variables the following question was investigated: Are there significant differences in work and life values of instructors in Oregon community colleges when examined by (1) sex of the instructor, (2) number of years teaching by the instructor, (3) age of the instructor, (4) highest degree held, (5) other employment - yes/no, (6) job location - geographical area of college, (7) vocational certificate of instructor - yes/no, and (8) parental education of instructor. For each of the above independent variables, a multivariate analysis of variance was performed separately on work values, terminal values and instrumental values, followed by univariate analyses of variance and Modified LSDs for all pair-wise mean comparisons, as appropriate. A11 statistical tests were at the .05 level of significant.

Although of minor importance to the purpose of this study to describe the values of comnunity college faculty, the relationships between work and life values were briefly examined. Coefficients of correlation between work and life (terminal and instrumental) values were calculated; the statistical hypothesis that the population coefficient is zero was tested for each correlation, using the .05 level of significance for each test.

Selected staff of Oregon community colleges were sent packets consisting of a biographical data sheet, an Ohio Work Values Inventory and a Rokeach Value Survey. Of the 984 instructors receiving the packet, 500 returned completed packets. This included 288 part-time instructors and 212 full-time instructors.

An analysis of the biographical data revealed the following sample characteristics: (1) approximately equal distribution by sex; (2) 
(2) approximately equal distribution across the college location categories of metro, urban, and rural/small city; (3) about one-half of the sample have 5 to 15 years of teaching experience; (4) over two-thirds hold a master's degree as the highest degree held; (5) over $60 \%$ are between 30 and 50 years of age; (6) almost two-thirds have no other employment; and (7) on the average, the parents of instructors are high school graduates.

Instructor Sample Analysis

Instructors in the sample assigned the greatest importance to the work value of Task Satisfaction, with a mean of 31.33 , and the least importance to the work value of Solitude with a mean value of 18.67 , as measured by the Ohio Work Values Inventory. Self Realization and Task Satisfaction were in the "great" range of values. Considerable importance was attached to the work values of Ideas/Data, Altruism, Independence, and Security. Moderate importance was assigned to the work values of Money, Control, Object Orientation, and Prestige. Solitude received some to moderate level of valuing. Reliability coefficients ranged from .821 to .930 .

On the Rokeach Terminal values, the sample placed the greatest value on Health and Self Respect (with mean rankings of 5.73 and 5.85 , respectively) and the least value on Social Recognition and National Security (with mean ranks of 13.18 and 13.13, respectively). In order by mean rankings, they valued Health, Self Respect, Family Security, Freedom, Inner Harmony, A Sense of Accomplishment, Wisdom, Mature Love, True Friendship, A world at Peace, An Exciting Life, Equality, A World 
of Beauty, A Comfortable Life, Salvation, Pleasure, National Security, and Social Recognition.

On the Rokeach Instrumental Values, the sample placed greatest value on Honest (with a mean rankings of 4.87 ) and least value on Obedient (with a mean ranking of 15.05). In order of mean rankings, they valued Honest, Responsible, Loving, Capable, Independent, Intellectual, Helpful, Broadminded, Courageous, Forgiving and Loyal, Logical, Imaginative, Ambitious, Self Controlled, Polite, Clean, and Obedient.

\section{Faculty Status}

A multivariate analysis (followed by univariate analyses) was performed, with faculty status as the independent variable and work values as the dependent variable. Six significant differences were found. Part-time faculty placed greater value than did full-time faculty on Altruism, Self Realization, Independence, Task Satisfaction, and Ideas Data; they placed less value on Object Orientation.

A multivariate analysis (followed by univariate analyses) was performed, with faculty status as the independent variable and Rokeach Terminal values as dependent variables; five significant differences were found. Part-time instructors placed more value on Self Respect and Wisdom and less value on A World of Beauty, National Security, and Pleasure than did full-time instructors.

A multivariate analysis (followed by univariate analyses) was performed, with faculty as the independent variable and Rokeach Instrumental values as dependent variables. Six significant differences were found. Full-time instructors placed less value on Helpful, Honest, and 
Responsible and more value on Clean, Obedient, and Polite than did part-time instructors.

Job Ass ignment

Using job assignment as an independent variable, a multivariate analysis of variance was performed three times, one time each for the three sets of dependent variables (work values, terminal values, and instrumental values); following each multivariate analysis, univariate analyses were performes on all dependent variables in the set. Following each significant univariate analysis, a modified LSD waS performed on each possible pair-wise comparison. The following significant differences were found.

The statistical hypothesis was rejected for eight work values. English and Health instructors placed greater value on Altruism than did Natural Science, Social Science, and Mathematics instructors; Health instructors also placed greater value on Altruism than did Secretarial Science instructors. Auto/Industrial Mechanics instructors placed greater value on Object Orientation than did any other group. Auto/ Industrial Mechanics and Secretarial Science instructors placed greater value on Control than did Natural Science, Social Science, and Mathematics instructors; Secretarial Science instructors also placed greater value on Control than did Health instructors. Health instructors placed greater value on Self Realization than did Mathematics instructors. Natural Science instructors placed less value on Money than did Auto/Industrial Mechanics, Secretarial Science, and Health instructors. Social Science instructors placed greater value on Solitude than did Business Education and Health instructors. Natural Science, Social 
Science, English, and Health instructors placed greater value on Ideas/Data than did Business Education instructors. Natural Science instructors placed less value on Prestige than did English, Secretarial Science, and Health instructors.

Ten Rokeach terminal values were significant. Social Science and English instructors placed more value on A World of Beauty than did Auto/Industrial Mechanics, Secretarial Science, and Health instructors. English instructors placed greater value than Auto/Industrial Mechanics instructors on Equality. Auto/Industrial Mechanics and Secretarial Science instructors placed greater value on Family Security than did Social Science instructors. Social Science instructors placed greater value on Freedom than did Auto/Industrial Mechanics Instructors. Natural Science, Auto/Industrial Mechanics, Secretarial Science, and Health instructors placed greater value on Health than did Social Science Instructors; Health instructors placed greater value on Health than did English teachers. Auto/Industrial Mechanics instructors placed more value on National Security than did Natural Science, Social Science, Mathematics, and English Instructors. Business Education instructors placed more value on National Security than did Natural Science instructors. Health instructors placed more value on Self Respect than did Secretarial Science instructors.

Twelve instrumental values were significant, but for two of these (Honest and Loving), no significant pair-wise differences were found. Social Science instructors placed less value on Ambitious than did Auto/Industrial Mechanics instructors. Business Education instructors placed less value on Broadminded than did Social Science instructors. 
Natural Science, Social Science, Mathematics, English, Secretarial Science, and Health instructors placed less value on Clean than did Auto/Indistrial Mechanics instructors; English instructors placed less value on Clean than did Business Education instructors. Health instructors placed less value on Courage than did Social Science and English instructors. Auto/Industrial Mechanics and Secretarial Science instructors placed less value on being Imaginative than did English instructors. Auto/Industrial Mechanics placed less value on Independent than Mathematics instructors. Auto/Industrial Mechanics instructors placed less value on Intellectual than did Social Science, Mathematics, and English instructors, while Secretarial Science instructors placed less value on Intellectual than did Social Science and English instructors. Mathematics instructors placed less value on Loyal than did Business Education and Secretarial Science. Auto/Industrial Mechanics instructors placed greater value on being Obedient than did English and Health instructors. Secretarial science instructors placed more value on Responsible than did Social Science and English instructors; Health instructors placed more value on Responsible than did Social Science and English instructors.

$\underline{\text { Sex }}$

Using sex as an independent variable, a multivariate analysis of variance was performed three times, one time each for the three sets of dependent variables (work, terminal, and instrumental values); following each multivariate analysis, univariate analyses were performed on all dependent variables in the set. Male instructors placed greater value than did female instructors on Object Orientation, Solitude, and 
Ideas/Data. Male instructors placed greater value on A Comfortable Life and An Exciting Life and less value on Self Respect and True Friendship than did female instructors. Male Instructors placed greater value on Self Control and less value on Loving and Loyal than did female instructors.

\section{Years Employed}

Using years employed as an instructor as the independent variable, a multivariate analysis of variance was performed on each dependent variable set. Following each multivariate analysis, univariate analyses were performed, followed by modified LSDS as appropriate.

Studying instructors by Years Employed as a teacher, significant differences were found in three work values. Instructors teaching over 20 years placed less emphasis on Object Orientation than did instructors who had taught from zero to 14 years. Those who had been teaching over 20 years also placed less emphasis on Control than did instructors who had been teaching from zero to four years. Instructors who had been teaching five to nine years place less emphasis on Self Realization than did instructors who had taught 15 to 19 years.

Significant differences were found in three RVS Terminal Values under number of years teaching. Instructors who had been teaching from 15-19 years placed less value on Mature Love than did instructors who had taught from zero to nine years. The 15-19 years group valued Pleasure less than did instructors who had taught from zero to four years, while instructors who had taught from zero to four years valued Self Respect less than did instructors who had been teaching 15 to 19 years. 
For instrumental values, the statistical hypothesis for the multivariate analysis was not rejected.

Age

Using age of instructor as the independent variable, a multivariate analysis of variance was performed three times, once for each dependent variable set (work values, terminal values, and instrumental values). Following each multivariate analysis, univariate analyses were performed, followed by modified LSD as appropriate. For two of the six significant work values (Object Orientation and Control), no significant pair-wise mean comparisons were found. Instructors in the 18-29 age group placed less value on Self Realization, Task Satisfaction, and Ideas/Data than did any other age group; they placed more emphasis on Prestige than did any other group.

With the Age category and Rokeach Terminal Values, significant differences were found on nine variables. Instructors in the age 18 through 29 age category placed greater value on A World of Beauty than did instructors who were ages 30-39 and age 50 and over. Instructors who were 30 and older placed greater value on Freedom, Health, and Wisdom and less value on National Security than did instructors who were from 18 to 29. Instructors who were ages 30-39 placed greater value on Mature Love than did those 50 and over. Pleasure was held in more value by young (18-29) instructors than by those over 39 years of age, while instructors from 30-39 years of age placed greater value on it (Pleasure) than did instructors age 50 and over. Instructors over 40 years of age placed greater value on Self Respect than did young (age 18-29) instructors. Social Recognition had more value placed on it by 
age 18-29 instructors than by those who were from ages 30-39 and those over 50 years of age.

Rokeach Terminal Values had some significant differences also in the Age Category. Young (18-29) instructors placed greater value on Clean than did instructors who were from $40-49$ years of age. Instructors 30 and over placed greater value on Honest and Responsible and less value on Obedient than did instructors who were under 30. Young (18-29) instructors placed more value on Polite than did instructors in the 50 and older group.

\section{Highest Degree Held}

Using highest degree held as an independent variable, a multivariate analysis of variance was performed three times, one time each for the three sets of dependent variables (work, terminal, and instrumental values). Following each multivariate analysis, univariate analyses were performed on all dependent variables in the set, followed by a modified LSD on each pair-wise mean comparisons, as appropriate.

Those holding Associate Degrees placed greater value on Object Orientation than did those instructors with Doctorates, Master's and Bachelor's Degrees. On the work value of Control, those instructors with Bachelor's and Associate Degrees placed greater value on that than did those with Doctorate and Master's Degrees. Instructors with Doctorates placed greater value on Independent than did those who held Master's and Associate Degrees. Those instructors with Other (no degree, generally) placed greater value on Solitude than did instructors with Master's, Bachelor's, and Associate Degrees. The instructors who held Doctorates placed greater value on Ideas/Data than did instructors 
who held Bachelor's Degrees. No significant difference between pair means was found on Money.

Five significant differences in Rokeach Terminal Values were found. Instructors with Master's Degrees placed greater value on Freedom than did instructors who had Associate Degrees. Instructors with Bachelors and Associate Degrees placed greater value on National Security than did instructors with Doctorates. Instructors with Doctorates placed greater value on True Friendship than did instructors with Master's Degrees. Those instructors with Doctorates placed greater value on Wisdom than did instructors with Bachelor Degrees. Although significant in the univariate analyses, no significant pair-wise mean comparison was found on A Comfortable Life.

Significant differences in Rokeach Instrumental Values were found in the values of Clean, where instructors with Associate Degrees placed more value than did instructors with Doctorates and Masters Degrees, and on the value of Intellectual where instructors with Doctorates placed more value than did those with Bachelors and Associate Degrees. Instructors with Masters Degrees placed more value on Intellectual than did those with Bachelors Degrees.

Other Job/No Other Job

Using other job and no other job as levels of the independent variable, a multivariate analysis of variance was performed on each set of dependent variables (work, terminal, and instrumentai values), followed by univariate analyses of variance as appropriate.

Eight significant differences in work values were found. Those who held another job placed less value on Self Realization, Task 
Satisfaction and Ideas/Data than did those who held no other job, while those who had no other job placed less value on Object Orientation, Control, Money, Solitude, and Prestige.

Significant differences were found in Rokeach Terminal Values for nine variables. Instructors holding no other job placed less value on An Exciting Life, National Security, Pleasure, and Social Recognition and greater value on A Sense of Accomplishment, Family Security, Health, Self Respect, and Wisdom than did instructors with other jobs.

Significant differences were found in Rokeach Instrumental Values for eight variables. Instructors who had another job placed less value on Honest, Logical, Loving, and Responsible and greater value on Ambitious, Clean, Obedient, and Polite than did instructors with no other job.

Community College Location

Using community college location as an independent variable, a multivariate analysis of variance was performed three times, one time each for the three sets of dependent variables (work, terminal, and instrumental values). Following each significant multivariate analysis, univariate analyses were performed, followed by Modified LSD tests as appropriate.

Significant differences were found on six work values. Other Urban instructors placed greater value on Object Orientation than did Small City/Rural instructors. Both Metro and Other Urban instructors placed less value on Self Realization than did Small City/Rural instructors. Small City/Rural instructors placed less value on Money than did Other Urban instructors. Metro area instructors placed less 
value on Task Satisfaction than did Small City/Rural instructors. Small City/Rural instructors placed less value on Solitude than did Other Urban instructors, and Small City/Rural instructors placed less value on Prestige than did Other Urban instructors. No significant difference was found for terminal and instrumental values.

Relationships Between OWVI and RVS Values

A coefficient of correlation for each scale of the OWVI with each terminal and instrumental value was calculated. (Please note that signs were reversed in order that a positive correlation would indicate that an increase in valuing on a work values scale is associated with an increase in valuing on a Rokeach scale).

Altruism was negatively correlated with A Comfortable Life, Pleasure, and Social Recognition and positively correlated with A World at Peace, Equality, Family Security, Salvation, True Friendship, and Wisdom. Object Orientation was negatively correlated with Self Respect, True Friendship, and Wisdom and positively correlated with National Security. Job Security was negatively correlated with An Exciting Life, A Sense of Accomplishment, and A World of Beauty and positively correlated with A Comfortable Life, Family Security, National Security, and Salvation. The value of Control was negatively correlated with A World at Peace, Equality, Mature Love, Self Respect True Friendship, and Wisdom, while positively correlated with A Comfortable Life, Family Security, National Security, Salvation, and Social Recognition. The value of Self Realization was negatively correlated with A World of Beauty, National Security, Pleasure, and Social Recognition and positively correlated with A Sense of Accomplishment, Health, Self 
Respect, True Friendship, and Wisdom. The value of Independent was negatively correlated with A World of Beauty and Salvation and positively correlated with An Exciting Life and Freedom. The scale of Money was negatively correlated with A World of Beauty, Equality, and Wisdom and positively correlated with A Comfortable Life, Family Security, and National Security. The scale of Task Satisfaction was negatively correlated with A World of Beauty, Equality, National Security, Pleasure, Salvation, and Social Recognition and positively correlated with Freedom, Health, Self Respect, True Friendship, and Wisdom. Solitude was negatively correlated with Mature Love, Salvation, Self Respect, True Friendship, and Wisdom and positively correlated with A Comfortable Life, An Exciting Life, Freedom, National Security, and Pleasure. Ideas/Data was negatively correlated with A Comfortable Life, National Security, Pleasure, Salvation and Social Recognition and positively correlated with An Exciting Life, A World at Peace, A Sense of Accomplishment, Freedom and Wisdom. Prestige was negatively correlated with Health, Self Respect, and Wisdom and positively correlated with An Exciting Life, A Sense of Accomplishment and Social Recognition.

Statistically significant correlations between the OWVI scales and Rokeach Instrumental Values were found. Altruism was negatively correlated with the RVS values of Clean, Imaginative, Independent, Intellectual, and Polite and positively correlated with Forgiving, Helpful, Honest, and Loving. Object Orientation was negatively correlated with Honest, Intellectual, Loving and Responsible and positively correlated with Ambitious, Clean, Imaginative, Logical and 
Obedient. OWVI Security was negatively correlated with Imaginative and Independent and positively correlated with Polite and Self Controlled. The scale of Control was negatively correlated with Broadminded, Honest and Loving and positively correlated with Ambitious, Clean and Obedient. Self Realization was negatively correlated with Clean, Obedient and Polite and positively correlated with Helpful, Honest, Loving, and Responsible. Independent was negatively correlated with Clean and Obedient and positively correlated with Courageous, Imaginative, Independent, Intellectual and Self Controlled. Money was positively correlated with Ambitious. Task Satisfaction was negatively correlated with Clean, Obedient and Polite and positively correlated with Helpfur, Honest, Loving and Self Controlled. Solitude was negatively correlated with Forgiving, Helpful, Honest, Loving and Responsible and positively correlated with Ambitious, Clean, Imaginative, Independent and Polite. Ideas/Data was negatively correlated with Ambitious, Clean, Obedient, and Polite and positively correlated with Broadminded, Honest, Imaginative, Independent and Intellectual. Lastly, the OWVI scale of Prestige was negatively correlated with Broadminded, Honest and Responsible, and positively correlated with Ambitious, Imaginative, Intellectual and Responsible.

\section{Conclusions}

The general conclusion of the study are reported upon in this section of the paper. A review of all biographical characteristics and findings are presented. 
Primary Purpose of the Study

The primary purpose of the study was to describe the work and life values of Oregon community college faculty in various teaching assignments.

Part-time, Full-time Values. In regard to work values, part-time faculty placed greater value than did full-time faculty on Altruism, Self Realization, Independence, Task Satisfaction and Ideas/Data and less value on Object Orientation. However, when examining the differences in the rank ordering of these two groups, they differed only in the reversal of Altruism and Independence and the reversal of object Orientation and Prestige, with full-time faculty placing greater value on Altruism and Object Orientation.

As to terminal life values, significant differences were found on the values of A World of Beauty, National Security, Pleasure, Self Respect and Wisdom. Part-time instructors placed more value on Self Respect and Wisdom and lesser value on A World of Beauty, National Security, and Pleasure than did full-time instructors. When examining the differences in the rank ordering of these two groups, they differed on 11 of the 18 values. Full-time instructors valued Health more than Self Respect with part-time instructors reversing these two. Full-time instructors valued in order: Inner Harmony, Freedom, A Sense of Accomplishment, Mature Love and Wisdom, while part-time instructors valued Freedom, Wisdom, Inner Harmony, A Sense of Accomplishment and Mature Love in order. The other values that were exchanged in order were A World of Beauty and Equality in order by full-time instructors and these values were changed in ranking by part-time instructors. The 
last two values in order by full-time instructors were National Security and Social Recognition and a reversal in order by part-time instructors.

Instrumental life values showed somewhat the same trends. Significant differences were found on the values of Clean, Helpful, Honest, Obedient, Polite, and Responsible, with full-time instructors placing less value on Helpful, Honest, and Responsible and more value on Clean, Obedient, and Polite than did part-time instructors. In ranking the values, the reversals included: Capable and Loving in order by full-time instructors and reversed by part-timers; Intellectual, Broadminded, Loyal, Courageous, Helpful, Forgiving, Imaginative, Logical and Ambitious by full-time instructors and Helpful, Intellectual, Broadminded, Courageous, Logical, Forgiving, Loyal, Ambitious and Imaginative by part-time instructors. The last four values of Self Controlled, Polite, Clean and Obedient were in the same order by both sets of instructors.

Although there were statistically significant differences in work and life values according to faculty status, the differences in the rank ordering of these two faculty groups were relatively minor and the absolute differences between the means for the different values were modest. Thus, it would appear that part-time and full-time faculty do not differ sufficiently to consider these classifications as important to an understanding of community college faculty. If we may extrapolate from this, tailoring for each group separately, in-service programs on value clarification and implications of instructor values in teaching and role modeling should not contribute to a more effective program. Value clarification would be a viable part of these programs overall. 
Life values and work values are much the same for both groups, so in-service and staff development programs that are designed for full-time instructors should in this respect be useful for part-time instructors. The problem for staff development personnel would be to determine the best and most useful delivery system, so that all groups would be served in a consistent and appropriate manner.

Teaching Field Values. Research showed that when instructors ranked work values according to the area of instruction in which they were teaching, all instructors placed Task Satisfaction in first place and Self Realization in second place. Ideas/Data occupied third place for Natural Science, Social Science and Math instructors, while Altruism was in third place for all other groups. Independent and Altruism alternated between groups for the most part in fourth and fifth place. Security and Money values were in the sixth and seventh places for all groups. In the last places were a mixture of Solitude, Object Orientation, Control and Prestige. In only one case, that of Auto/Industrial Mechanics who ranked object Orientation in fifth place was there a great discrepancy among these ranking. Eight of the rankings showed significant pair-wise mean comparisons, but again the differences were relatively minor and the absolute differences between the means for the different values were modest. This follows closely Klampe (1983) and Waggoner's (1983) studies of secondary teachers and public school administrators. Ten terminal values were rejected with seven (A World of Beauty, Equality, Family Security, Freedom, Health, National Security and Self Respect) showing significant pair-wise mean comparisons, and 12 instrumental values being rejected with 10 
(Ambitious, Broadminded, Clean, Courageous, Imaginative, Independent, Intellectual, Loyal, Obedient and Responsible) showing significant pair-wise mean comparisons. There are no clear-cut decisions to be made when looking at the groupings by teaching assignments. Each grouping has their own considerations in looking at values from this perspective. They do show some consistency overall in that rank ordering is not tremendously different. As one aspect of organizing staff development programs for all staff, utilizing value clarification as a component of a program, there need not be specific sequences developed for each group. Nevertheless, for an understanding of the values of community college faculty, teaching assignment was found to be an important variable; logical differences were found among the groups. For example, the Auto/Industrial Mechanics group placed greater value on Clean and Object Orientation than did any other group. In an inservice program aimed at values, clarification and an understanding of the role of values in teaching, both variation in values within and between groups should be examined. The staff development program would need to determine the best and most appropriate delivery system, so all groups within each teaching assignment would be served to meet their needs.

Secondary Purposes of the Study

The values of the community college faculty were examined by sex, number of years of teaching experience, age, degree held, other employment (yes/no) and college location.

Sex of Instructor. Studying the area of work value relationships in the male/female field, of the 11 Ohio Work Values, three were found to be 
significant. Male instructors valued Object Orientation, Solitude, and Ideas/Data Orientation more than did female instructors. That males value working with their hands and working in the absence of other people more than females is consistent with the sex differences found in other studies (Hales and Fenner, 1973b), with public school children; Hales and Hartman, 1978a, 1978b, with university students and vocational-technical college students; and Waggoner, 1983, public school administrators.

Four terminal values and three instrumental values were found to be significantly different from a total of 36 values. A Comfortable Life, An Exciting Life and Control were valued more by male instructors and female instructors valued Self Respect, True Friendship, Loving and Loyal more. This indicated that there were few differences in these two groups when studying them according to their sex. Of the total 47 values in all three categories, 10 (or 21\%) were found to be significantly different but the magnitude of these differences was relatively minor. Although the differences are relatively small, they seem to reflect societal differences. Considering sex differences in an in-service program working with value clarification and values in teaching is appropriate. Gilligan (1982) stated, "In view of the evidence that women perceive and construe social reality differently from men and that these differences center around experiences of attachment and separation, life transitions that invariably engage these experiences can be expectod to involve women in a distinctive way." (p. 171). Women's development tends to lend to a less violent life, but also to a maturity that comes from interdependence and taking care. 
Number of Years Teaching. When statistical research was completed on Number of Years Teaching, no great discrepancies appeared. Five work values, four terminal values and one instrumental value showed significant differences. Those teachers who had been teaching over 20 years placed less value on Object Orientation and Control than did most other groups, while instructors who had been teaching 5-9 years placed less value on Self Realization than did instructors who had been teaching 15-19 years. Three terminal values, Mature Love, Pleasure and Self Realization showed significant difference, with instructors who had been teaching the longest valuing Mature Love and Pleasure generally less than other groups, except for Self Respect, where instructors who had been teaching the least valuing it less than the teachers with most experience. Only one instrumental value showed significant difference and no pair-wise mean comparison was found. Nine of 47 total values were significantly different, again showing that only minor variations appeared when studies were done on the category of number of years teaching. These differences, however, suggest that some value change may occur with teaching experience, although it may only reflect changes in societal values over the years.

Age of Instructor. In researching values on instructors by age, more significant differences appeared. Six work values, nine terminal values and five instrumental values showed significant differences. It seems that the age of instructors allowed for more variations than did the other categories mentioned thus far. Almost half (20 of 47) of the values were significantly difference when studying instructors by age. 
This may be reflected by the fact that the categories to some extent reflect life stages which might also be related to value changes such as a young adult establishing a career, a family and status in the community; established in a career and having changing family responsibilities with older children; changing family constellations with adult children; and approaching retirement. All these changes by age probably reflect a greater change than would other categories. Fully realizing that age differences, although the ages of faculty surveyed showed that almost two thirds are between the ages of 30 and 50 , are one factor of value changes, this concept should be fully explored and information disseminated to in-service participants so that they may realize the importance of age on value clarification procedures.

Degree held by Instructor. Five work values, four terminal values and two instrumental values indicated significant differences when studying categories of instructors according to the degree they held. Eleven of 47 total values showed differences, indicating that approximately one-fourth of the values showed significant pair-wise mean comparisons. Again, as in many of the categories, these were minor variations, so trying to categorize and teach values and value clarification according to categories by degree would seem to be of some importance, but not of major concern.

Values Held by Other Employment. When research was done by the category of instructors holding no job other than teaching or having another job and teaching, significant differences were found in eight work values, 
nine terminal values and eight instrumental values. Of the 47 total values, 25 showed significant differences, thus leading to the conclusion that there were demonstrable differences when studying this category. It would seem that another job held other factors that could be included in a work shop on values and those qualities would be valuable for instructors to be made aware of so they could be pursued to insure that each instructor was made aware of the fact that there may be these differences and that they should make note of them.

Geographic Location of College. Geographic differences of teaching in a metropolitan area, other urban area or a small city/rural area were also studied by the researcher. Six work values showed significant differences and no terminal or instrumental values showed differences. It seems that work values could very well be part of any type of workshop in order to help in value clarifications for this category.

Correlation of OWVI and the Rokeach Value Survey. The two surveys showed that of the 396 correlations between OWVI and the RVS, 162 were significant at the .05 level. This was $41 \%$ of the total. The signs of the correlation indicated a logical relationship of the two instruments. Only the RVS terminal value of Inner Harmony showed no correlation with any value of the OWVI. The instrumental values of Capable and Loyal were the only two values not significantly correlated with at least one OWVI value. These seemed to indicate that there were significant relationships between work and life (terminal and instrumental) values of instructors in all categories. 
Reliability and Intercorrelation of the OWVI Scales.

The reliability of the OWVI was proven satisfactory. Reliability coefficients ranged from .821 for the Independence scale to .930 for the scale of Money, very similar to Waggoner's (1983) reliability for urban area public school administrators. Scale intercorrelation of the OWVI ranged from .77 (Self Realization with Task Satisfaction) to -.27 (Altruism with Solitude); $53 \%$ were between -.19 and +.19 .

These intercorrelations are about what one would expect. Since Task Satisfaction and Self Realization are extensions to the world of work of the components of Self Realization (Self Actualization and Acceptance of Seif) as postulated by Combs and Snygg (1959), a correlation of this magnitude is reasonable. The negative correlation of Solitude and Altruism $(-.27)$, Independence $(+.30)$, and Object Orientation $(+.29)$ suggests that people who like to work in isolation from other people generally do not value jobs in which they help other people, but value working with their hands and having independence in their jobs. The positive correlations among the scales of Self Realization, Task Satisfaction, Ideas/Data, Altruism and Independence suggest that those who value Self Realization and Task Satisfaction may value Independence, Altruism and/or Ideas/Data as means to realizing those two values. The positive correlations among Money, Control and Prestige suggests the possibility that these values are means to controlling others by ascendency over them (Horney, 1945). The intercorrelations found in this study are similar to those found by Waggoner (1983) and reported by Fenner and Hales (1974). 
Implications for Community Colleges

The purpose of this research was to study the work and personal values of Oregon community college instructors to ascertain whether significant differences were to be found among groups of instructors. In general, differences were found to be moderate and from this the implications are that satisfactory in-service programs that are presented should be made available to all instructors in the community college system. The differences which can be attributed to faculty status appear to be minor and this variable is likely to contribute little to an understanding of values. Similarly, differences between male and female faculty members were relatively minor, suggesting that this variable is of little importance in understanding the values of community college faculty. Nevertheless, because sex differences are found in the values of the general population, one might wish to include sex differences in an in-service program aimed at values clarification and values in teaching.

In order to provide a supportive environment for community college students, faculty need to be cognizant of their values and how their values may influence their teaching and relationships with students. Thus, values clarification, the differences in values across teaching fields, and the influences of values on teaching are appropriate topics for in-service educational program for faculty. In addition, one might suspect that values clarification would be beneficial for students, perhaps included in an occupational/careers orientations program.

The method of presenting studies on values and value clarification for these instructors would need to be ascertained. Work and life 
values, according to most authors reviewed, are an integral part of instruction and work shops incorporating these values would seem to be necessary to achieve maximum potential of all instructors.

I would editorially comment that a sense of belonging and being made to feel a part of the community college has to be a paramount concern, and using a work shop to promote values and value clarification could be a part of this process. Part-time faculty need to be a great concern of administration, boards of directors and full-time faculty. For too long a time, part-time faculty have been looked on as outsiders or a lesser part of the faculty. Many times they are the only contact a student has with the college and so they become a symbol. If they are a strong symbol, they become a symbol of a strong college and vice versa. Helping them to become strong should be a major consideration for any staff development program, in conjunction with the entire college. Extending to part-time faculty a sense of belonging and being made to feel an integral part of the system has to become a high priority of all facets of the college. Until community colleges place more emphasis on the training of part-time faculty, particularly in the area of values, in-service programs will not be of as much value as they could be. As the demand increases for the use of part-time faculty and community college budgets feel the constraints placed on them, it would seem imperative that these actions be a part of the concerns that community college administrations address. Values are an integral part of teaching and when addressing teaching concerns, values need to be addressed for the information of teaching habits. 
Recommendation for Further Research

A longitudinal study over time assessing work and personal values of full-time and part-time instructors to ascertain changes throughout their careers would indicate areas where in-service programs would be of benefit.

Part-time in-service programs, to institute change agents in participants, and then a study to research whether changes had become a part of their value system would be of help to colleges as well as participants.

A study to determine the proper proportions of part-time and full-time faculty would be of benefit to all institutions in the state. 


\section{BIBLIOGRAPHY}




\section{BIBLIOGRAPHY}

Albert, E., \& Kluckholm, C. A selected bibliography on values, ethics and esthetics. Glencoe, IL: The Free Press, 1959.

Allport, G. W. Pattern and growth in personality. New York: Holt, Rinehart and Winston, 1961.

Anderson, N. Likableness ratings of 555 personality trait words. Journey of Personality and Social Psychology, 1968, 9, p. 272-279.

Bateson, G. Personality and the behavior disorder. New York: Ronald Press, 1944.

Bem, J. Beliefs, attitudes and human values. Belmont, CA: Brooks-Cole Publishing Co., 1970.

Bennett, S., \& Bowers, D. An introduction to multivariate techniques for social and behavioral sciences. New York: John Wiley and Sons, 1976.

Biddle, J. Role theory, New York: Academic Press, 1979.

Bills, E. The effect of value on learning. Journal of Personality, $1952,21(2), 217-222$.

Blai, B. Value and perceptions of a private junior college faculty: Public community college faculties and students. Bryn Mawr, PA: Harcum Junior College, May, 1972. (ERIC Document Reproduction Service No. ED 061 945)

Brawer, F. B. Values and the generation gap: Junior college freshman and faculty. Washington, D.C., June 1971. (ERIC Clearinghouse of Junior College Information, ED 050 724)

Canning, J. W. (Ed.). Values in the age of confrontation. Columbus, OH: Charles E. Merrill Publishing Co., 1970.

Cohen, A. M. (Ed.). Toward a professional faculty. San Francisco: Jossey-Bass, 1973.

Cohen, A. M. Dateline 79: Heretical concepts for the community college. Beverly Hills, CA: Glencoe Press, 1979.

Cohen, A. M., \& Brawer, F. B. The two-year college instructor today. New York: Praeger Publishers, 1977.

Combs, A. W. The professional education of teachers. Boston: Allyn \& Bacon, 1965. 
Combs, A. W. \& Blume, R. A. \& Newman, A. J. and Wass, H. L. The Professional Education of Teachers. Boston: Allyn \& Bacon, 1974.

Combs, A. W. \& Hvila, D. L. \& Purkey, W. W. Helping relationships. Boston: Allyn \& Bacon, 1971.

Combs, A. W., \& Snygg, D. Individual behavior. New York: Harper and Roe, 1959.

Cooley, C. Human nature and the social order. New York: Horton, Schocken Books, 1964.

Cross, K. P. Accent on learning. San Francisco: Jossey-Bass Publishers, Inc., 1977.

Davis, R. Lofquist, L. A psychological theory of work adjustment, Minneapolis: University of Minnesota Press, 1984.

Dewey, J. Human nature and conduct. New York: The Modern Library, 1930.

Diekhoff, J. S. The domain of the faculty. New York: Harper \& Brothers, Publishers, 1956.

Dukes, W. F. Psychological studies of values. Psychological Bulletin, 1955, 52(1), 7-12.

Eble, K. E. Professors as teachers. San Francisco: Jossey-Bass, Publishers, Inc., 1972.

Eddy, E. M. Becoming a teacher. New York: Teachers College Press, Columbia University, 1969.

Feather, N. T. Values in education and society. New York: The Free Press, 1975.

Feather, N. Expectations and actions. Hillsdale, N.J.: Lawrence Erlbaun Associates, Publisher, 1982.

Fenner, B. J. The development of the Ohio work values inventory: An investigation of internal characteristics (Doctoral dissertation, Ohio University, 1972). Dissertation Abstracts International, 1972, (University Microfilms No. 81-09166, 27) 33-04A, p. 1433

Fenner, B. J. \& Hales, L. W. Ohio Work Values Inventory: Manual. Athens, OH: Authors, 1974.

Finn, J. D. \& Mattsson, I. Multivariate analysis in education research. Chicago: National Educational Resources, 1978. 
Fishburn, P. C. Decision and value theory. New York: John Wiley and Sons, Inc, 1964.

Frankel, J. Junior college faculty job satisfaction. Washington, D.C.: National Institute of Education (DHEW), 1973.

Fried, C. An anatomy of values. Cambridge, MA: Harvard University Press, 1970.

Gabriel, J. Children growing up. New York: American Elsevier Publishing Co., 1968.

Gabriel, R. American values. Hestport, CN: Greenwood Press, 1974.

Gilligan, C. In a Different Voice. Cambridge, MA: Harvard University Press, 1982 .

Ginsberg, M. Mind and belief: Psychological ascription and the concept of belief. New York: Humanities Press, 1972.

Ginzberg, E., Ginsburg, S., Axelrad, S. \& Herma, J. Occupational choice. New York: Columbia University Press, 1951.

Ginzberg, E. Career guidance. New York: McGraw-Hill Book Co., 1971.

Gleazer, E. J., Jr. The community college: Values, vision and vitality. Washington, D.C.: American Association of Community and Junior Colleges, 1980.

Goldbecker, S. S. Values teaching. Washington, D.C.: National Education Association, 1976.

Green, P. E. Analyzing multivariate data. Hinsdale, IL: The Dryden Press, 1978.

Greene, E. B. Measurements of human behavior. New York: The Odyssey Press, New 1941.

Hales, A. K. A comparative study of the work values of nurses versus the work values of nurse trainees. Unpublished Master's thes is, Ohio University, Athens, 1977.

Hales, L. W. Selected psychometric characteristics of the Ohio Work Values Inventory. A paper presented at the annual meeting of the American Association for Counseling and Development, New York, April, 1985.

Hales, L. H. \& Fenner, B. J. Work values of 5 th, 8th ind 11th grade students. Vocational Guidance Quarterly, 1972, 20, 199-203.

Hales, L. W. \& Fenner, B. J. Ohio work values inventory. Athens, $\mathrm{OH}$ : Authors, 1973a. 
Hales, L. W., \& Fenner, B. J. Sex and social class differences in work values. Elementary School Guidance and Counseling, 1973b, 8 , 26-32.

Hales, L. W., \& Hartman, T. P. Measuring the work values of technical college students: The Ohio Work Values Inventory. Measurement and evaluation in guidance, 1978a, 11 (3), 169-174.

Hales, L. W. \& Hartman, T. Personality, sex and work values, Journal of experimental education, 1978b, 47, 16-21.

Hales, L. W., \& Yackee, K. Self-concepts, sex and work values. A paper presented at the annual meeting of the American Educational Research Association, Chicago, 1974.

Hall, E. W. Our knowledge of fact and value. Chapel Hill, NC: The University of North Carolina Press, 1961.

Hammond, M. Motives related to vocational choices of college freshmen. Journal of Counseling Psychology, 1956, 19, 257-261.

Handy, R. Value theory and the behavioral sciences. Springfield, IL: Charles C. Thomas, Pub., 1969.

Hartman, R. S. The structure of value, foundation of scientific axiology. CarbondaTe, IL: Southern Illinois University Press, 1967.

Hartman, T. The relationships among personality variables and work values of Ohio public technical college students. (Doctoral Dissertation, Ohio University, 1977). Dissertation Abstracts International, 1977, 38-05A p. 2557 (University Microfilm No. 81-09166, 27).

Herrick, C. J. The thinking machine. Chicago: The University of Chicago Press, 1929.

Holland, J. The psychology of vocational choice. Waltham, MA: Blaisde 71 Publishing Co., 1966.

Holland, J. G. Making vocational choice. Englewood Cliffs: Prentice Hall, 1973.

Holland, J. G. \& Skinner, B. F. The analysis of behavior. New York: McGraw-Hill Book Co., 1961.

Horney, K. Our inner conflicts. New York: Norton, 1945.

Horowitz, L. M. Elements of statistics for psychology and education. New York: McGraw Hill Book Co., 1974.

Inlow, G. M. Values in transition. New York: John Wiley and Sons, Inc., 1972. 
Jacob, P. E. Changing values in college. New York: Harper and Bros., Publishers, 1957 .

Kerlinger, F. N. Foundations of behavior research. New York: Holt, Rinehart and Winston, 1973.

Klampe, C. M. The work values of secondary teachers: A comparative study by teaching assignment. Unpublished master's thesis, Portland State University, Portland, OR, 1983.

Kluckholm, C. Toward a general theory of action. Cambridge, MA: Howard University Press, 1957.

Krech, D., Crutchfield, R. S., \& Bollachey, E. L. Individual in society. New York: McGraw-Hill Book Co., $19 \overline{62 .}$

Laird, 3. The idea of value. New York: Augustus M. Kelley, Publisher, 1969 .

Landsberger, H. L. Hawthorne revisited. Ithaca, NY: Cornell University, $19 \overline{58 .}$

Lecky, P. Self-consistency. New York: The Island Press, 1945.

Lepley, R. (Ed.). Value: A cooperative inquiry. New York: Columbia University Press, 1949.

Lepley, R. (Ed.). The language of value. New York: Columbia University Press, 1957.

Lerner, M. Values in education. Bloomington, IL: Phi Delta Kappa, 1976.

Lombardi, J. Part-time faculty in community colleges, Topical Paper No. 54. Washington, D.C.: Nationa? Institute of Education (DHEW), 1975.

London, H. B. The culture of a community college. New York: Praeger Publishers, 1978.

Loos, W. (Ed.). The nature of man. Freeport, NY: Books For Library Press, 1950.

Lovejoy, A. 0. Reflections on human nature. Baltimore: The John Hopkins Press, 1961.

McCready, W. C., \& Greeley, A. M. The ultimate values of the american population. Beverly Hills, CA: Sage Publications, 1976.

Maddi, S. R. Personality theories. Homewood, IL: The Dorsey Press, 1980. 
Marascuilo, L. A., \& McSweeney, M. Nonparametric and distribution free methods for the social sciences. Monterey, CA: Brooks/Coie Publishing Co., 1977.

Maslow, A. H. Motivation and personality. New York: Harper, 1954.

Maslow, A. H. (Ed.). New knowledge in human values. Chicago: Henry Regnery Co., 1979.

Miller, C. H. Age differences in occupational values of college men. Journal of Counseling Psychology, 1954, 1, 190-192.

Miller, G. A. The magical number of seven, plus-or-minus two: Some limits on our capacity for processing information. Psychologica? Review, 1956, 63, 81-97.

Morris, C. Varieties of human values. Chicago: University of Chicago Press, 1956.

Morris, C. Signification and significance. Cambridge, MA: The M. I. T. Press, 1964.

Neff, W. S. Work and human behavior. New York: Atherton Press, 1968.

Nie, N. H., Hul1, C. H., Jenkins, J. G., Steinbrenner, K., and Brent, D. H. Statistical Package for the Social Sciences. Second Edition. New York: Mc-Graw Hill Books, 1975.

O'Banion, T. (Ed.). Developing staff potential. San Francisco: Jossey-Bass, 1977.

Overstreet, H. A. The mature mind. New York: W. W. Norton \& Co., 1949.

Park, Y. Junior college faculty: Their values and perceptions. Washington, D.C.: American Association of Community and Junior Colleges, 1971.

Parker, D. H. Human values. New York: Harper and Brothers, Publishers, 1931.

Presno, C., \& Presno V. The value realms. New York: Teachers College Press, Columbia University, 1980.

Pepper, S. C. A digest of purposive values. Berkley: University of California Press, 1947.

Pritchett, B. J. Values and perceptions of community college professional staff in Oregon. (Doctoral dissertation, Oregon State University, 1973) Dissertation Abstracts International, 1973, 34A P. 1104-A (University Microfilm No. 81-09166, 37). 
Pruyser, P. W. Between belief and unbelief. New York: Harper \& Roe, Pubiishers, 1974.

Pugh, G. E. The biological origin of human values. New York: Basic Books, Inc., Publishers, 1977.

Pullias, E. V., \& Young, J. D. A teacher is many things. Bloomington: Indiana University Press, 1968.

Rescher, N. Introduction to value theory. Englewood Cliffs: Prentice-Hal1, 1969.

Roe, A. The psychology of occupation. New York: John Wiley and Sons, Inc., 1956 .

Roethlisberger, F. J. Man-in-organization. Cambridge, MA: Harvard University Press, 1968.

Roethlisberger, F. J., \& Dickson, W. J. Management and the worker. Cambridge, MA: Harvard University Press, 1961.

Rokeach, M. Values in America. American Psychologist, 1951, 26 (5), 30-70.

Rokeach, M. The open and closed mind. New York: Basic Books, Inc., 1960.

Rokeach, M. Beliefs, attitudes and values. San Francisco: Jossey-Bass, Inc., Publishers, 1968.

Rokeach, M. The nature of human values. New York: The Free Press, 1973.

Schiebe, K. E. Beliefs and values. New York: Holt, Rinehart and Winston, $1 \overline{970 .}$

Sewe11, D. H., Brydon, C. W., \& Plosser, W. D. Report of a statewide survey about part-time faculty in California community colleges. Sacramento: California Community and Junior College Association, 1976.

Spranger, E. Types of men. New York: Max Niemeyer Verlag, Johnson Reprint Corporation, 1928.

Stefflre, B. Tentative manual for vocational values inventory. East Lansing: Michigan State University, 1962.

Steffire, B., \& Grant, W. H. Theories of counseling. New York: McGraw Hill Book Co., $19 \overline{75 .}$

Super, D. E. Appraising vocational fitness. New York: Harper and Bros., 1949 . 
Super, D. E. The psychology of careers. New York: Harper and Bros., Pubiisners, 1957 .

Super, D. E. Opportunities in psychology careers. New York: Universal Publishing and Distributing Corp., 1968.

Super, D. E., Crites, J. 0., Humme l, R. C., Moser, H. P., Overstreet, P. L., \& Warnath, C. F. Vocational development: A frame work for research. New York: Bureau of Publications, Columbia University, 1957.

Taylor, H. O. Human value and verities. New York: The Macmillan Co., 1928.

Tiedeman, D. Career development: Choice and adjustment. New York: College Entrance Examination Board, 1963.

Waggoner, J. C. Metropolitan school administrators: Work values, role perceptions and burnout. (Doctoral Dissertation, Portland State University, Portland, OR, 1983). 44/11, p. 3241-A, DA 8403980.

Wilson, R. C., \& Gaff, J. G. College professors and their impact on students. New York: John Wiley and Sons, 1975. 
APPENDIX A

Ins truments 


\section{PLEASE NOTE:}

Copyrighted materials in this document have not been filmed at the request of the author. They are available for consultation, however, in the author's university library.

These consist of pages:

228-236 QUESTIONNAIRE PACKET

237-241 VALUE SURVEY

\section{University}




\section{APPENDIX B}

Sample Letters from Researcher and Other Participants 
MEMO

To: Presidents of Oregon community colleges

(Members of OCCA)

FROM: John F. Bohan $\left(D^{D}\right)$

RE: Research proposal - Values of Part-Time and Full-Time Oregon Community College Faculty in Selected Instructional Areas

I am beginning research work on my dissertation regarding values as indicated above. Milton Rokeach, a pre-eminent scholar on values has stated that "Values do exist in people and seem to be instituted at an early age. A value is an enduring belief in which a mode of conduct or end-state of existence is preferable ... A person's teaching ability is directed to some extent by their personal value system."

This research is designed to compare similarities and differences through work values, instrumental (modes of behavior) values and terminal (end-states of existence) values in the following areas of community college instruction: Natural Science, Social Science, Mathematics, English Composition, Auto/Industrial Mechanics, Business Education, Secretarial Science and Health Occupations. These groupings are represented in community college education throughout the state of Oregon and translate into four areas of transfer education and four areas of terminal vocational education.

The questions to be answered are:

1. Are there significant differences in the Work Values that part-time and full-time faculty bring to the area of instruction in Oregon community cclleges as determined by the Ohio Work Values Inventory?

2. Are there significant differences in the Work Values of community college faculty assigned to various educational areas?

3. Are there significant differences in the Instrumental and Terminal Values of Oregon community college part-time and full-time faculty members as determined by the Rokeach Value Survey?

4. Are there significant differences in the Instrumental and Terminal Values of community college faculty assigned to various educational areas?

I feel that the survey will answer, for college administrators, questions that pertain to proper ratios of part-time and full-time faculty to be employed and gaining better perspective on salary scales for the various groups of instructors, among others.

It is my hope that the OCCA members will endorse this project, as I feel that by working with the various personnel departments that contact may be made with instructors in the community colleges throughout the state of Oregon. 


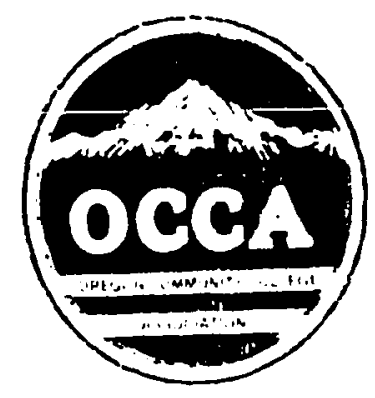

March 21, 1993

John Bohan

Clackamas Community College

19600 S. Molalla Ave.

Oregon City, OR 97045

Dear John:

This is to inform you of OCCA's endorsement of your proposed survey of full-time and part-time faculty in Oregon's community colleges. In the interests of tir:e, we skipped our usual step of appointing a review conmittee, relying instead on review of your proposal as part of the March 7 meeting of the Council of Presidents.

I urge you to contact the president of each college you wish to participate in your survey to remind them of the scope and tining of the activity on each campus before you distribute the survey instruments.

Please feel free to use this letter of endorsement in your contacts with the colleges.

cc: Community College Presidents Bob Hamill

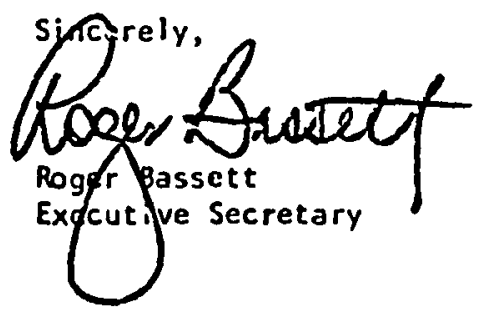


April 5, 1983

(Designated person)

Dear Sir:

My thanks to your group for endorsing my dissertation project in surveying the full and part-time community college instructors in Oregon as shown by the enclosed letter.

I am making contact with each community college through your office. It would be appreciatud if you could appoint a contact person on : ur campus for me to work through. I will be callin, your office at the end of this week for the name, and through them I will be doing the surveying. I would appreciate using your college campus mailing service to contact instructors for distribution and retreival of the survey. Any suggestions to help make it more feasible for your college system would be helpful.

Enclosed is a copy of the memorandum that was distributed to presidents that were present at the meeting in Salem on March 7, 1983. It does delineate the dimemsions of the survey and to which areas of instruction it will be pre. sented.

Thank you for your help and considera.ion in the surveying. I feel it will be beneficial to each college and to the instructional area within the school.

Sincerely yours,

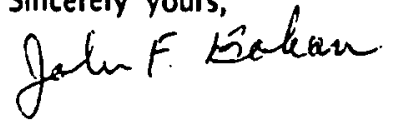

John F. Bohan

(Clackamas Community College)

18701 Madrona Drive

Oregon City, OR 97045

Home Phone - 657.6020

Office Phone 657-8400, Ex. 238

Enclosures:

Letter of Endorsement

Memo to Presidents 
MEMIO

TO: (Designated person)

FROM: John Bohan

RE: Surveys for Full and Part-Time Instructors iw Oregun Communitv Colleges

Enclosed are two packets of surveys that need to be distributed to faculty at your respective community college.

The two packets are the following:

(1) Full-time teacher packets which are ready for distribution. The names have been obtained from the Oregon Community College Personnel Directory for 1983. If you note any not on your staff, I'd appreciate renaming the packet accordingly. Please keep track on the $b x k$ of the Part-time faculty list.

(2) Part-time faculty packet. Each packet needs a nume on the pachet and the name onto the corresponding number on the list. There is a penciled number (to be erased) in each left hand upper corner that must correspond with name placed on list and envelope. No mumber should appear on the outside envelope whn the packet is sent out. The numbers of part-time faculty needed for each instructional area is shown on the enclosed sheet, as well as the varied headings that your instructors may be using for class name.

I do appreciate your time and help in distributing these snd having them returned. When they are returned, please ship them back and I will return the postage involved in the shipping.

Thanks again.

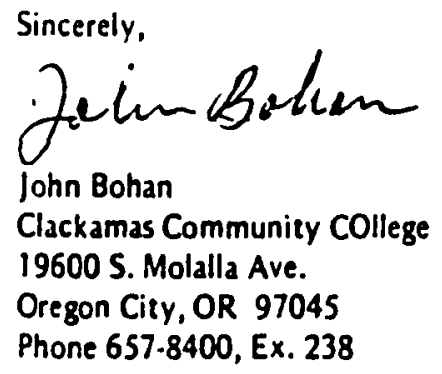

Home Phone 657.6020 
June 8,1983

Dear Colleague:

My thanks to you for helping out in my task of surveying faculty members in Oregon community colleges as to their work and personal values. I would appreciate you sending in the return envelopes of any that have been turned into you. The postage will be reimbursed by me to your school or you personally, if that would be easier for you to ou.

The data will be analyzed shortly, and if your returns could be included, it would help in the reliability of the research.

Please package up what you have, and return them to me at:

C?ackamas Cormunity College

ittn.: John Bohan

19600 So. Molalla Ave.

Oregon City, OR. 97045

Again, my thanks for your help and consideration.

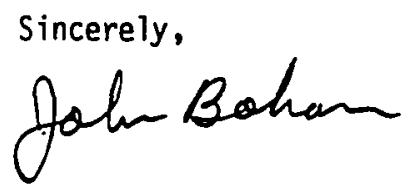

John Bohan 


\section{APPENDIX C}

Rokeach Value Survey Results by Other Authors 
APPENDIX C (1)

RVS TERMINAL VALUES BY AUTHOR

\begin{tabular}{|c|c|c|c|c|}
\hline \multicolumn{2}{|c|}{ Bohan } & \multirow[t]{2}{*}{ Brawer* } & \multirow[t]{2}{*}{ Park** } & \multirow[t]{2}{*}{ Bla $i \star \star \star *$} \\
\hline Full-time & Part-time & & & \\
\hline $\begin{array}{l}\text { Health }{ }^{\star \star \star \star} \\
\text { Self Respect } \\
\text { Family Sec. } \\
\text { Inner Harm. } \\
\text { Freedom } \\
\text { Sense of Acc. } \\
\text { Fature Love } \\
\text { Wisdom } \\
\text { True Friend. } \\
\text { World at Pea. } \\
\text { Exciting Life } \\
\text { Worid of Bea. } \\
\text { Equality } \\
\text { Comfort. Life } \\
\text { Salvation } \\
\text { Pleasure } \\
\text { National Sec. } \\
\text { Social Recog. }\end{array}$ & 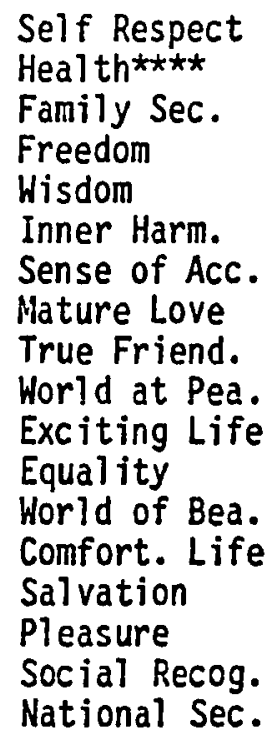 & 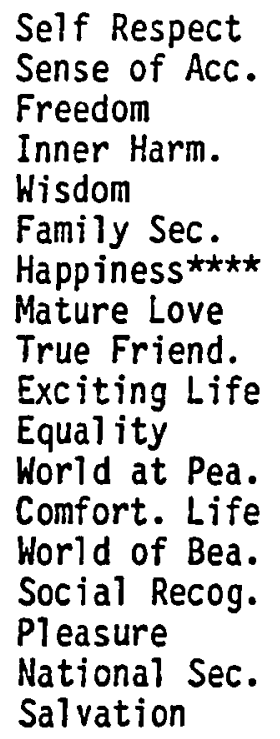 & 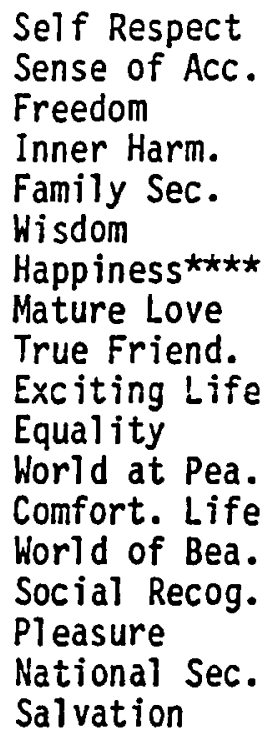 & 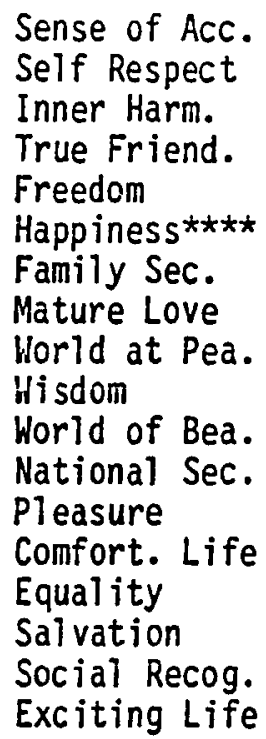 \\
\hline
\end{tabular}

*Brawer (1971) p.

**Park (1971) p.

$\star * \star B l a i(1972) p$.

$\star \star \star \star$ The value "Happiness (Contentedness)" was el iminated from the 1 ist of terminal values and was replaced with "Health (Physical and mental well-being)". Happiness was deleted not because it was considered to be unimportant, but because empirical research had shown it to be less useful than the remaining values in discriminating among various groups. Health in the terminal value system was added because many users had suggested that it would be especially useful and interesting to have information about this value in particular. 
APPENDIX C (2)

RVS INSTRUMENTAL VALUES BY AUTHOR

\begin{tabular}{|c|c|c|c|c|}
\hline \multicolumn{2}{|c|}{ Bohan } & \multirow[t]{2}{*}{ Brawer } & \multirow{2}{*}{ Park } & \multirow[t]{2}{*}{ Blai } \\
\hline Funll-time & Part-time & & & \\
\hline 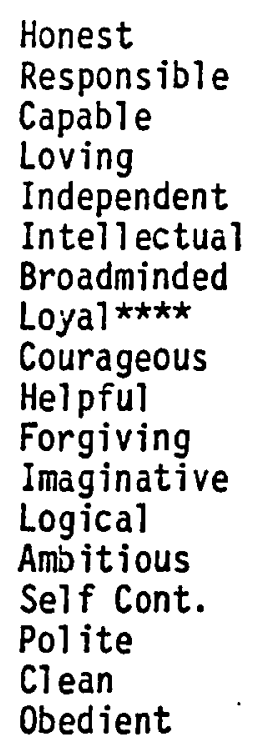 & $\begin{array}{l}\text { Honest } \\
\text { Responsible } \\
\text { Loving } \\
\text { Capable } \\
\text { Independent } \\
\text { Helpfui } \\
\text { Intellectual } \\
\text { Broadminded } \\
\text { Courageous } \\
\text { Logical } \\
\text { Forgiving } \\
\text { Loyal } \star \star \star \star \\
\text { Ambitious } \\
\text { Imaginative } \\
\text { Self Cont. } \\
\text { Polite } \\
\text { Clean } \\
\text { Obedient }\end{array}$ & 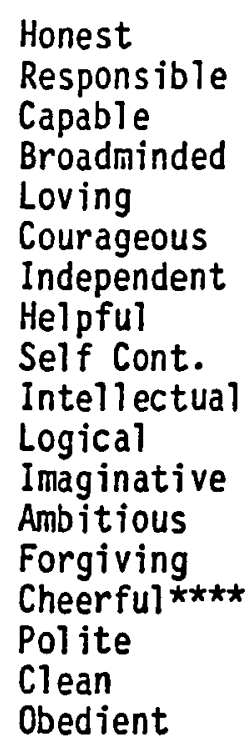 & 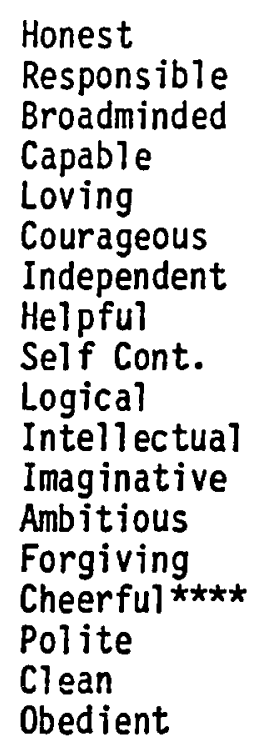 & 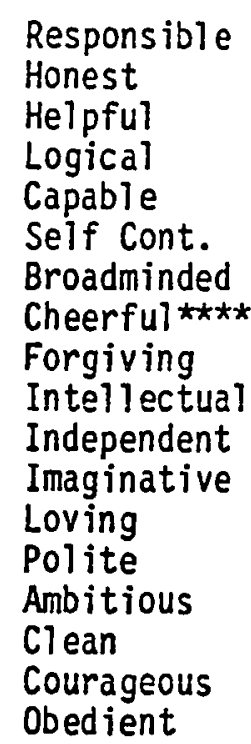 \\
\hline
\end{tabular}

*Brawer (1971) p.

$\star \star$ Park (1971) p.

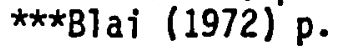

$\star \star \star \star *$ The value "Cheerful (Lighthearted, joyful)" was el iminated from the list of instrumental values. It was replaced with "Loyal (Faithful to one's friends)" in the most recent form of the survey. Cheerful was deleted not because it was considered to be unimportant, but because empirical research had shown it to be less useful than the remaining values in discriminating among various groups. Loyal in the instrumental value system was added because many users had suggested that it would be especially useful and interesting to have information about this value in particular. 
APPENDIX C (3)

RVS TERMINAL VALUES BY AUTHOR

\begin{tabular}{|c|c|c|}
\hline \multicolumn{2}{|l|}{ Bohan } & \multirow[t]{2}{*}{ Pritchett* } \\
\hline Ful1-time & Part-time & \\
\hline Health & Self Respect & Self Respect \\
\hline Self Respect & Health & A Sense of Accomp. \\
\hline Family Security & Family Security & Family Security \\
\hline Inner Harmony & Freedom & Freedom \\
\hline Freedom & Wisdom & Wisdom \\
\hline Sense of Accomp. & Inner Harmony & Inner Harmony \\
\hline Mature Love & Sense of Accomp. & Mature Love \\
\hline Wisdom & Mature Love & Happiness \\
\hline True Friendship & True Friendship & An Exiting Life \\
\hline World at Peace & World at Peace & True Friendship \\
\hline An Exciting Life & An Exciting Life & A World at Peace \\
\hline A World of Beauty & Equality & Equality \\
\hline Equality & A World of Beauty & A World of Beauty \\
\hline A Comfortable Life & A Comfortable Life & A Comfortable Life \\
\hline Salvation & Salvation & Social Recognition \\
\hline Pleasure & Pleasure & Pieasure \\
\hline Nationa? Security & Social Recognition & National Security \\
\hline Social Recognition & National Security & Salvation \\
\hline
\end{tabular}

*Pritchett (1973) p. 88 
APPENDIX C (4)

RVS INSTRUMENTAL VALUES BY AUTHOR

\begin{tabular}{lll}
\hline & Bohan & Pritchett* \\
\hline Full-time & Part-time & \\
\hline Honest & Honest & Honest \\
Responsible & Responsible & Responsible \\
Capable & Loving & Capable \\
Loving & Capable & Broadminded \\
Independent & Independent & Helpful \\
Intellectual & Helpful & Courageous \\
Broadminded & Intellectual & Independent \\
Loyal & Broadminded & Forgiving \\
Courageous & Courageous & Loving \\
Helpful & Logical & Ambitious \\
Forgiving & Forgiving & Imaginative \\
Imaginative & Loyal & Intellectual \\
Logical & Ambitious & Logical \\
Ambitious & Imaginative & Cheerful \\
Self Controlled & Self Controlled & Self Controlled \\
Polite & Polite & Polite \\
Clean & Clean & Clean \\
Obedient & Obedient & Obedient \\
& & \\
\hline
\end{tabular}

*Pritchett (1973) p. 97 